\title{
Ideological Exclusion, Plenary Power, and the PLO
}

\author{
Philip Monrad $\dagger$
}

Section 901 of the Foreign Relations Act, Fiscal Years 1988 and 1989, guarantees that some aliens will not be excluded or deported because of their ideological expression or association. Resident aliens and members of the Palestine Liberation Organization are excepted from section 901 and are, therefore, subject to ideological exclusion. This Comment criticizes those exceptions, arguing that they violate the first amendment.

Before addressing the first amendment challenge, the author argues that the plenary power doctrine, which severely limits judicial review of immigration legislation, should not bar these challenges for either of two reasons: (1) because the doctrine should be categorically abandoned, or (2) because there exists a first amendment exception to the doctrine.

After concluding that courts are not prohibited from entertaining the first amendment challenge, the Comment evaluates the exceptions to section 901 by applying the test in United States v. O'Brien, with reference to Brandenburg v. Ohio. Working under the assumption that the congressional purpose behind the exceptions is to interdict terrorism, the Comment concludes that the exceptions are overly broad, since they do not involve an individualized determination of propensity to commit terrorism, and they add nothing that is not already provided by a different exception to section 901 for terrorist activity. Furthermore, the Comment argues that if the purpose behind the PLO exception is to express antagonism toward the $P L O$, the exception still fails the O'Brien test, since there are other ways to pursue that interest without encroaching on first amendment interests.

U.S. immigration law is dominated by the doctrine of the plenary power of Congress and the executive to regulate immigration, largely unreviewed by the judiciary for conformity with constitutional constraints. One area in which the extraconstitutionality of immigration law has been particularly striking is the historical ${ }^{1}$ and continuing ${ }^{2}$ practice of exclusion and deportation of aliens based solely on ideology-beliefs,

$\dagger$ B.A. 1970, Hamline University; candidate for J.D. and M.A. (Jurisprudence and Social Policy) 1990, Boalt Hall School of Law, University of California, Berkeley.

The author wishes to thank Deborah Valoma and Petra Valoma for their patience and support; David Cole, Caroline P. Blum and Marc Van -Der Hout for their inspiration and assistance; and Naomi Roht-Arriaza, Jennifer Upham, Laurine Tuleja and John Chase for their editorial tenacity.

1. See infra notes 31,37 and accompanying text.

2. See infra notes 8-26 \& 33-35 and accompanying text. 
expression and association-with no evidence of past or probable future criminal activity.

In 1987 Congress reformed this practice by prohibiting exclusion or deportation "because of any past, current, or expected beliefs, statements, or associations which, if engaged in by a United States citizen in the United States, would be protected under the Constitution of the United States."3 Although the reform is welcome and long overdue, it came freighted with exceptions. It does not apply, inter alia, to resident (immigrant) aliens, ${ }^{4}$ nor does it apply to "members" of the Palestine Liberation Organization (PLO). ${ }^{5}$

This Comment argues that these two exceptions to the statutory prohibition against ideological exclusion and deportation should be repealed by Congress ${ }^{6}$ or invalidated by the courts, in both cases because the exceptions violate the first amendment of the Constitution. ${ }^{7}$ A necessary threshold argument is that the plenary power doctrine does not remove this legislation from the reach of constitutional restraints. Before proceeding with those arguments, a brief description of two current instances of ideological exclusion illustrates that the issues at stake are of

3. Foreign Relations Authorization Act, Fiscal Years 1988 and 1989, Pub. L. No. 100-204, $\S 901,1987$ U.S. CODE CONG. \& ADMIN. News (101 Stat.) 1331, 1399-1400 (codified at 8 U.S.C. $\S 1182$ note (Supp. V 1987)).

4. Section 901, supra note 3, was amended on October 1, 1988 by the Foreign Operations, Export Financing, and Related Programs Appropriations Act, 1989, Pub. L. No. 100-461, §555, 1988 U.S. CODE CONG. \& ADMIN. NEWS (102 Stat.) 2268, 2268-36. The amendment withdrew the protection of the earlier application to all aliens, restricting its application, instead, only to nonimmigrant aliens. For further discussion of this amendment see infra notes 74-75 and accompanying text. A fundamental distinction in alien status is between those staying temporarily in the United States, such as tourists, students and business visitors, and those staying indefinitely as permanent residents to eventually become eligible for citizenship. The former are nonimmigrant aliens. The latter are immigrant aliens or lawful permanent resident aliens. See T. ALEINIKOFF \& D. Martin, Immigration: Process and Policy 97-109 (1985). Throughout this Comment, immigrant aliens are referred to by the more descriptive phrase "resident aliens," except where necessary to avoid confusion in discussing statutes, which use the term "immigrant aliens."

5. Foreign Relations Authorization Act, Fiscal Ycars 1988 and 1989, Pub. L. No. 100-204, $\S 901(b)(3), 1987$ U.S. CODE CONG. \& ADMIN. News (101 Stat.) 1331, 1399-1400 (codified at 8 U.S.C. $\S 1182$ note (Supp. V 1987)). For further discussion of this amendment see infra note 77 and accompanying text.

6. The form of the argument in this Comment is an appeal to the federal judiciary to undertake judicial review (in an appropriate case) of these exceptions to section 901, urging judicial invalidation for constitutional reasons. The arguments apply as well, however, to Congress, whose members have all taken the same oath to uphold the constitution as have federal judges. See generally Brest, The Conscientious Legislator's Guide to Constitutional Interpretation, 27 STAN. L. REv. 585 (1975). In that sense, this Comment urges legislative repeal of the exceptions as well. The Comment does not make arguments expressly directed to a legislative forum, however, nor does it include equitable or "political" reasons in favor of or against the exceptions.

7. The first amendment provides in part: "Congress shall make no law . . . abridging the freedon of speech, or of the press, or the right of the people peaceably to assemble . . ." U.S. CONST. amend. I.

The exceptions also raise equal protection concerns. As discussed infra notes 298-304 and accompanying text, this Comment confines its analysis to the first amendment. 
vital concern to many long-term permanent resident aliens and their families, as well as to this country's commitment to an open society tolerant of opposing viewpoints.

In April 1986, three individuals, all of Palestinian descent, returned to the United States from a two-week trip to the Middle East where they allegedly attended a conference in Syria sponsored by the Palestine Youth Organization, an affiliate of the Popular Front for the Liberation of Palestine (PFLP). ${ }^{8}$ One traveler was a U.S. citizen; the other two were permanent resident aliens. The differing treatment subsequently accorded these travelers by the Immigration and Naturalization Service (INS) graphically illustrates how fundamentally the plenary power doctrine has affected immigration law.

Since the U.S. citizen had committed no crime nor incited anyone else to do so, he clearly could not be penalized for attending the conference. He was simply exercising his right to free expression and association. 9 The resident aliens, however, were less fortunate. Exclusion proceedings were brought against them under those provisions of the McCarran-Walter $\mathrm{Act}^{10}$ authorizing exclusion from the United States for membership in "subversive" organizations. ${ }^{11}$ On June 10, 1986, one of the resident aliens was found excludable and forced to leave the country.

The government instituted exclusion proceedings against the other traveler, Fouad Rafeedie, under a little-used provision of the McCarranWalter Act $^{12}$ which authorizes exclusion or deportation ${ }^{13}$ without a hearing and on the basis of undisclosed information if, in the INS's opinion,

8. The facts of this case are taken from Rafeedie v. INS, 688 F. Supp. 729, 730-35 (D.D.C. 1988), unless noted otherwise. Since there has not been a hearing on the facts of the case, see infra note 25 , the facts presented are those alleged by the government.

9. Under Brandenburg v. Ohio, 395 U.S. 444 (1969), the first amendment protects "subversive" or inflammatory speech (including association) unless it is "directed to inciting or producing imminent lawless action and is likely to incite or produce such action." Id. at 447.

10. Pub. L. No. $82-414,66$ Stat. 163 (1953) (codified as amended at 8 U.S.C. $\$ \S 1101-1557$ (1982)), discussed at infra notes 47-55 and accompanying text. The McCarran-Walter Act is officially known as the Immigration and Nationality Act (INA). Citations to the INA are commonly given to the section numbers of the INA as well as to its codification in the United States Code. This Comment cites to both.

11. The aliens were charged under subsections 212(a)(27), (28), and (29) of the INA, 8 U.S.C $\$ 1181(a)(27)-(29)$ (1982), which cover a wide spectrum of subversive belief, advocacy, and affiliation. See infra notes $47-55$ and accompanying text. The record does not disclose which of the many clauses in these subsections formed the basis of the specific charges against the aliens.

12. INA $\S 235$ (c), 8 U.S.C. $\S 1225$ (c) (1982).

13. Exclusion is the process by which aliens are barred from entering or reentering the United States. Deportation is the process by which aliens already present in the United States are expelled. The grounds for both ideological exclusion and deportation are substantially identical. Compare INA $\S 212,8$ U.S.C. $\S 1182$ (1982) (exclusion grounds) with INA $\S 241,8$ U.S.C. $\S 1251$ (1982) (deportation grounds). Deportation proceedings, however, provide greater procedural protection for the alien. See Schuck, The Transformation of Immigration Law, 84 Colum. L. REV. 1, 19 n.96 (1984). The sharpness of the distinction between exclusion and deportation is blunted, however, by the rule that a resident alien who leaves the United States is subject to exclusion, not deportation, on 
the disclosure of information would be prejudicial to the public interest, safety, or security. ${ }^{14}$ Rafeedie, a resident of the United States for 20 years with U.S. citizen wife and children, challenged this summary exclusion as a violation of both procedural due process and first amendment protected expression and association. ${ }^{15}$

The INS refused to disclose the basis for its conclusion that Rafeedie's readmission to the United States would "be prejudicial to the public interest, or endanger the welfare, safety, or security of the United States." 16 Without revealing its source, the INS did allege: "Rafeedie is a high ranking member of the PFLP, in the United States. He has been active in both fundraising and recruiting activities for the PFLP. He fought with the PFLP in Lebanon in 1982, and claimed to have been wounded in combat." 17 Rafeedie denies that he is a member of any organization described in the McCarran-Walter Act, although he admits that he has been politically active while living in the United States and has been outspokenly critical of U.S. policies towards the Middle East.

The government does not allege that Rafeedie has engaged in illegal activity, nor even that his activities create the imminence or likelihood of illegal activity. Thus, if he were a U.S. citizen, the activities alleged would clearly be constitutionally protected. ${ }^{18}$ As a resident alien, however, Fouad Rafeedie does not enjoy such freedom of expression and association, as he quickly discovered.

The INS's attempt to exclude Rafeedie marked the second time in as many years that the government has attempted to use the McCarranWalter Act's ideological provisions against resident aliens who espoused unpopular views or causes. In the middle of the night of January 26, 1987, the INS and the FBI burst into the homes of six Palestinians and a Kenyan woman, put them in shackles, and charged them as deportable for affiliating with an organization that advocates the economic, international and governmental doctrines of world Communism through written or printed publications. ${ }^{19}$

return, as in the case of Mr. Rafeedie. See United States ex rel. Volpe v. Smith, 289 U.S. 422 (1933);

T. Aleinikoff \& D. MARTIN, supra note 4, at 323-47.

14. Summary exclusion under INA $\$ 235(\mathrm{c}), 8$ U.S.C. $\S 1225(\mathrm{c})$, is reserved for the subversive, ideological grounds of deportation and exclusion, INA $\S 212(\mathrm{a})(27),(28)$, and (29), 8 U.S.C. $\S 1181(\mathrm{a})(27)-(29)$. Section 235(c) has seldom been used since the McCarthy era and has never been applied against a lawful permanent resident alien. See Rafeedie v. INS, 688 F. Supp. 729, 742-43 \& n.31 (D.D.C. 1988).

15. Rafeedie v. INS, 688 F. Supp. 729 (D.D.C. 1988). See infra note 25.

16. INA $\S 212(a)(27), 8$ U.S.C. $\$ 1182(a)(27)$ (1982). Rafeedie, 688 F. Supp. at 734.

17. Rafeedie, 688 F. Supp. at 734.

18. See Brandenburg v. United States, 395 U.S. 444 (1969) and discussion infra note 297.

19. INA $\S 241(\mathrm{a})(6)(D), 8$ U.S.C. $\S 1251(\mathrm{a})(6)(\mathrm{D})$ (1982). The facts presented here are taken from American-Arab Anti-Discrimination Committee v. Meese, 714 F. Supp. 1060 (C.D. Cal. 1989) [hereinafter ADC v. Meese]. 
Three months later the government abandoned these charges against the seven aliens. ${ }^{20}$ Instead, the five aliens who were in the country on nonimmigrant visas were charged with technical visa violations. The other two, Khader Hamide and Michel Shehadeh, who were permanent resident aliens, ${ }^{21}$ were charged under provisions of the McCarranWalter Act authorizing the deportation of aliens "who advocate or teach or who are members of or affiliated with any organization that advocates or teaches ... the unlawful damage, injury, or destruction of property."22

After a protracted series of legal maneuvers and $3 \frac{1}{2}$ years of investigation, the only evidence the FBI produced was that the aliens possessed pro-Palestinian magazines which could have been bought at a newsstand. ${ }^{23}$ In response to questioning about the Los Angeles deportations, FBI Director William Webster admitted that these aliens "had not been found to have engaged themselves in illegal activity ... [and that] if these individuals had been United States citizens, there wonld not have been a basis for their arrest." 24

Both of these recent instances of ideological exclusion are currently being litigated. Rafeedie ${ }^{25}$ and the two Los Angeles resident aliens,

20. ADC v. Meese, 714 F. Supp. at 1063. The abandonment of ideological deportation charges against the nonresidents occurred shortly after the relcase of adverse publicity regarding the case. This publicity coincided with the leak of a secret INS "Contingency Plan" recommending the wholesale registry, detention, and deportation of aliens based on Libyan and Palestinian nationality. See L.A. Times, Feb. 6, 1987, Part I, at 3, col. 4.

21. At the time of their arrests, Khader Hamide had been a lawful permanent resident alien in the United States for ten years; Michel Shehadeh, for twelve. Call for Justice, Newsletter of the Committee for Justice to stop the McCarran Act Deportations, August 1987, at 6.

22. INA $\S 241(\mathrm{a})(6)(\mathrm{F})(\mathrm{iii}), 8$ U.S.C. $\$ 1251$ (a)(6)(F)(iii). ADC v. Meese, 714 F. Supp.at 1063.

23. The Untouchables, NATION, Mar. 21, 1987, at 348.

24. Nomination of William $H$. Webster, to be director of Central Intelligence, Hearings Before the Senate Select Comm. on Intelligence, 100th Cong., 1st Sess. 94-95 (1987).

25. Rafeedie v. INS, 688 F. Supp. 729 (D.D.C. 1988). Besides a first amendment challenge, this civil action seeks, inter alia, a hearing on the charges against Rafeedie. On June 15, 1988, Judge Joyce Hens Green granted a preliminary injunction against the summary exclusion procceding, ordering further testimony to determine whether Rafeedie, as a returning resident alien, is entitled to a hearing that comports with due process. The district court also ordered testimony on whether his alleged fundraising and recrniting activities constituted "terrorist activity" under section 901 of the Foreign Relation Authorization Act, Fiscal Years 1988 and 1989, Pub. L. No. 100-204, § 901, 1987 U.S. Code Cong. \& ADMIN. NEwS (101 Stat.) 1331, 1399-1400 (codified at 8 U.S.C. § 1182 note (Supp. V 1987)), discussed at infra notes 62-83 and accompanying text. The INS appealed the injunction. On July 21, 1989, the Court of Appeals for the District of Columbia affirmed the district court's preliminary injunction prohibiting the continuation of the section 235 (c) summary exclusion proceeding and remanded to the district court to determine whether such a proceeding comports with due process. Rafeedie v. INS, 880 F.2d 506 (1989). The court held that Rafeedie's alleged nefarious purpose in traveling abroad does not affect the process that is due to him when determining whether the government's allegations are accurate. Id. at 519-25. The court of appeals directed the district court to determine due process by applying the balancing test set forth in Mathews v. Eldridge, 424 U.S. 319 (1976). 
Shehadeh and Hamide, ${ }^{26}$ filed lawsuits claiming that ideological exclusion and deportation violate the first amendment. They also claimed that the proceedings against them are barred by the recent amendment to the INA prohibiting ideological exclusion and deportation. That amendment, found at section 901 of the Foreign Relations Authorization Act, Fiscal Years 1988 and $1989,{ }^{27}$ prohibits deportation or exclusion for activity that would be constitutionally protected for U.S. citizens. The government responded that the amendment is inapplicable because the aliens fall within an express exception to section 901 for members of the PLO and because the statute, by its terms, protects only nonimmigrant aliens (most commonly students, tourists, and business people). When the resident aliens challenged the constitutionality of these exceptions, the government responded that the plenary power doctrine placed the provisions beyond judicial review.

The constitutionality of those exceptions to section 901 is the subject of this Comment. The Comment argues that the resident-alien ${ }^{28}$ and PLO exceptions to the general prohibition of ideological exclusion and deportation should be held invalid because they violate the first amendment guaranties of freedom of expression and association. Before reaching the first annendment issue, however, the Comment addresses the threshold issue of the judiciary's power to review immigration legislation.

Traditionally, courts have characterized the congressional and executive powers over immigration as "plenary." Under the plenary power doctrine, the judiciary has minimal-if any-authority to review the constitutionality of the actions of the other two branches in immigration matters. Thus, any challenge to section 901's constitutionality must begin by surmounting the hurdle of the plenary power doctrine. This Comment suggests two challenges to the plenary power doctrine, either of which permits the courts to adjudicate the validity of the exceptions to section 901 . The first challenge categorically rejects the plenary power doctrine, arguing that it is anachronistic and unsupported by precedent or rationale. The second challenge more modestly demonstrates that

26. ADC v. Meese, 714 F. Supp. 1060 (C.D. Cal. 1989). On January 26, 1989, District Judge Stephen Wilson held that the McCarran-Walter ideological exclusion provisions are overbroad because they encompass and effectively constrain first amendment protected activity and therefore are facially unconstitutional. For further discussion of this case, see infra notes 187, 196, 368 \& 379 and accompanying text.

27. Pub. L. No. 100-204, $\S 901,1987$ U.S. Code Cong. \& Admin. NEws (101 Stat.) 1331, $1399-1400$ (codified at 8 U.S.C. $\$ 1182$ note (Supp. V 1987)).

28. As discussed above, supra note 4, this Comment refers to immigrant aliens as "resident aliens." Strictly speaking, however, the restriction of section 901 to nonimmigrant aliens does not leave only resident aliens excepted. Aliens applying from abroad for immigrant (resident) status are also within the exception. Thus the restriction of section 901 to nonimmigrants crcates an cxception for resident aliens and for would-be resident aliens. For simplicity and economy, the Comment refers to the exception for immigrant aliens as a resident-alien exception. 
existing case law supports a first amendment exception to the plenary power doctrine. ${ }^{29}$

Part I begins with a brief description of the statutory grounds for ideological exclusion and their recent temporary reform in section 901 . Part II describes the plenary power doctrine and summarizes both the categorical and first amendment challenges to it. Part III argues that neither the political question doctrine nor the doctrine of judicial deference in matters of foreign relations precludes judicial review where, as here, fundamental individual rights are involved. Part IV applies the United States $v$. O'Brien $^{30}$ test to the section 901 exception for immigrant aliens, concluding that the exception unjustifiably denies first amendment protection to U.S. citizens and lawful resident aliens. Part V applies the same test to the PLO exception, concluding that another exception-for terrorists-to section 901's protection renders the PLO exception superfluous, overly broad, and unjustifiably restrictive of first amendment liberties.

\section{IDEOLOGICAL EXCLUSION AND ITS STATUTORY REFORM}

Aliens have been excluded and deported from the United States for ideological reasons since at least $1904 .^{31}$ Despite protestations to the

29. A logical conclusion of such challenges to the plenary power doctrine is that ideological exclusion under the McCarran-Walter Act is, itself, unconstitutional, and therefore section 901 is superfluous. That argument was the conclusion of the district court judge in ADC v. Meese, discussed infra at note 187 and accompanying text. That argument has also been ably and thoroughly made by academic commentators such as Scanlan, Aliens in the Marketplace of Ideas: The Government, the Academy, and the McCarran-Walter Act, 66 TEx. L. REv. 1481 (1988); Shapiro, Ideological Exclusions: Closing the Border to Political Dissidents, 100 HARv. L. REv. 930 (1987); Tilner, Ideological Exclusion of Aliens: The Evolution of a Policy, 2 GEo. IMMlGR. L.J. 1 (1987); Voigt, Visa Denials on Ideological Grounds and the First Amendment Right to Receive Information: The Case for Stricter Judicial Scrutiny, 17 CuMB. L. REv. 139 (1986); Note, Immigration and the First Amendment, 73 CALIF. L. REv. 1889 (1985) (authored by Steven Burr) [hereinafter Note, Immigration]; Note, Constitutional Limits on the Power to Exclude Aliens, 82 ColuM. L. REv. 957 (1982) (authored by Richard Hahn) [hereinafter Note, Constitutional Limits]; Note, First Amendment Limitations on the Exclusion of Aliens, 62 N.Y.U. L. REV. 149 (1987) (authored by Judy Wertzel) [hereinafter Note, First Amendment].

30. 391 U.S. 367 (1968).

31. Turner v. United States, 194 U.S. 279, 294 (1904) (upholding the deportation of a residentalien anarchist for advocating a general strike in protest of labor conditions, stating that Congress could exclude "political philosophers innocent of evil intent."). For further discussion of Turner, see infra note 196.

In the 1919-20 Palmer raids, thousands of aliens were imprisoned and more than five hundred deported. These actions were undertaken pursuant to legislation authorizing deportation of "any alien who at any time after entry shall be found advocating or teaching [subversion]," Act of Feb. 3, 1917 , ch. $29, \S 19,39$ Stat. 874,889 , or of aliens who were "members of or affiliated with any organization that entertains a belief in, teaches, or advocates the overthrow by force or violence of the Government of the United States," Act of Oct. 16, 1918, ch. 186, § 1, Pub.L.No. 65-221, 40 Stat. 1012,1012 , or of aliens who "write, publish, . . circulate . . [or] . . have in their possession 
contrary, ${ }^{32}$ the cases of American-Arab Anti-Discrimination Committee $(A D C)$ v. Meese ${ }^{33}$ and Rafeedie v. $I N S^{34}$ demonstrate that exclusion based on ideology continues today. ${ }^{35}$ Ideological exclusion ${ }^{36}$ has resulted

[subversive literature]," Act of June 5, 1920, ch. 251, § 1(d), 41 Stat. 1008, 1009. For further discussion, see J. Higham, Strangers in the Land: Patterns of American Nativism, 1860. 1925 at 229-31 (1955); Tilner, supra note 29, at 31-47.

32. In testimony before the House Subcommittee on Immigration, Refugees, and International Law, the Department of State's Legal Advisor, Abraham Sofaer, stated that "the provisions of [INA] section 212(a)(28) remain the target of strong and valid criticism as undemocratic and inconsistent with our national policy in favor of the free and open competition of ideas. We have no wish to exclude any person simply because of his or her personal political views or associations." Exclusion and Deportation of Aliens: Hearings Before the Subcomm. on Immigration, Refugees, and International Law of the House Comm. on the Judiciary, 100th Cong., 1st Sess. 35 (1987) [hereinafter Hearings, Exclusion and Deportation of Aliens].

In his testimony, Sofaer quoted both Attomey Gcneral Edwin Meese and Secretary of State George Shultz as expressing opposition to ideological exclusion. Secretary Shultz' views were given in a January 12, 1986 speech before the organization of Poets, Essayists and Novelists (PEN):

This administration is committed, and I am personally committed, to protecting free expression of all political ideas.... I've taken very seriously my Department's role in reviewing proposed visa denials that could affect free expression. It has never been the approved policy of the U.S. to deny visas merely because the applicant wants to say that he disapproves of the U.S. or one if its policies ... . No denial is ever based on a person's abstract beliefs.

quoted at id. at 33.

Similarly, Attorney General Meese stated at the National Press Club on February 25, 1986: "I think that ideological opinion should not be a basis for exclusion from the U.S." quoted at id.

In apparent contradiction to these statements is the State Department's denial of a visa application by Italian playwright Dario Fo with the explanation that "Fo's record of performance with regard to the United States is not good. Dario Fo has never had a good word to say about [the United States]." Cross Left, Village Voice, June 2, 1980, at 86, col. 3 (quoting Vittorio Brode of the State Department's Italian Desk); see also Shapiro, supra note 29 , at 939 n. 59.

33. 714 F. Supp. 1060 (C.D. Cal. 1989). As this Comment went to press, the INS charged Shehadeh and Hamide again, based on the same facts, under a new and slightly different deportation provision. The most recent charge is for being "a member of or affiliated with [an] organization [the PFLP] that advocates or teaches the duty, necessity, or propriety of the unlawful assaulting or killing of an officer or officers (either of specific individuals or of officers generally) of the Government of the United States or of any organized government, because of his or their official character." INA 241(a)(6)(F)(ii), 8 U.S.C. $\$ 1251$ (a)(6)(F)(ii). In the Matter of Shehadeh, No. A30 660 528; In the Matter of Hamide, No. A19 262 560. Both charges were filed on July 21, 1989.

The facts and constitutional issues underlying these new charges appear to be no different from those underlying the nearly identical charges held unconstitutional in ADC v. Meese, 714 F. Supp. 1060 (C.D. Cal. 1989), discussed at supra note 26. Since the INS, Shehadeh, and Hamide were named parties in the ADC v. Meese case, it is unelear how, in good faith, the INS could bring these renewed charges in apparent defiance of Judge Wilson's holding.

34. 688 F. Supp. 729 (D.D.C. 1988).

35. Recent actions by the Bush administration indicate that it, too, is willing to engage in ideological exclusion and deportation. In February 1989, the State Department excluded Gerry Adams from the United States. Adams is a member of the British Parliament and president of Sinn Fein, a lawful political party in Ireland. The State Department maintains that Adams is a member of the Irish Republican Army, and therefore exeludable. Adams has brought suit challenging his exclusion. Adams v. Baker, No. CV-88-1701-S (D. Mass. filed July 22, 1988). See Cole, The 1952 McCarran-Walter Act: Is It Irrelevant in Today's World?, National Law Journal, May 29, 1989, at 22; see also supra note 33.

36. As noted, supra note 13, both exclusion and deportation can be based on ideology. As used 
in visa denials and deportations of many celebrated political and literary figures $^{37}$ and has generated widespread criticism, both in the popular press $^{38}$ and in scholarly commentary, ${ }^{39}$ decrying the practice as intolerant, xenophobic, and a violation of constitutional values.

Despite occasional imdications of discomfort, ${ }^{40}$ the Supreme Court, with rare exceptions, ${ }^{41}$ has repeatedly refused to constrain the practice of ideological exclusion by invoking the plenary power doctrine. Consequently, the effect of the plenary power doctrine has been to deny aliens the basic protections of the Constitution in their dealings with the federal

in this Comment, "ideological exclusion" encompasses both exclusion and deportation based on ideology, in other words, based solely on an alien's expression, belief, or association.

37. A partial list, beginning with Emma Goldman, includes Graham Greene, Farley Mowat, Carlos Fuentes, Gabriel Garcia Marquez, Dario Fo, Yves Montand, Pablo Neruda, Hortensia Allende, Thomas Borge, Nino Pasti, and Margaret Randall. For accounts of the ideological exclusion of these aliens and further general discussion of recent ideological exclusion, see Shapiro, supra note 29, at 930; Note, First Amendment, supra note 29, at 149; Note, Immigration, supra note 29, at 1889; LAWYers COMM. FOR HUMAN RightS \& THE WATCH COMMS., THE REAGAN ADMINISTRATION'S RECORD ON HUMAN RIGHTS IN 1985 at 152-54 (1986).

These clearly ideological visa denials generated a number of well-publicized lawsuits. See, e.g., Harvard Law School Forum v. Shultz, 633 F. Supp. 525 (D. Mass. 1986) (enjoining the Secretary of State from refusing to permit a PLO observer to the U.N. to travel to Massachusetts in order to participate in a debate about Middle East policy), vacated without opinion, 852 F.2d 563 (1st Cir. 1986); NonGovernmental Organization Committee on Disarmament v. Haig, No. 82-6147 (S.D.N.Y. June 10, 1982) (LEXIS, Genfed library, Dist. file), (upholding visa denials to 320 aliens) most of whom were Japanese) to observe a UN disarmament conference) aff'd mem., 697 F.2d 294 (2d Cir. 1982); Abourezk v. Reagan, 785 F.2d 1043 (1986), aff'd by an equally divided court, 484 U.S. 1 (1987) (invalidating and remanding for reconsideration visa denials to Thomas Borge, Interior Minister of Nicaragua; and Nino Pasti, former Italian Senator, NATO General, and current peace activist with the World Peace Council), discussed in Note, First Amendment, supra note 29, at 16871, and infra note 154; Allende v. Shultz, 605 F. Supp. 1220 (D. Mass. 1985) (invalidating visa denials to Hortensia Allende, widow of slain Chilean President Salvador Allende, and member of World Peace Council).

38. See, e.g., Don't Let the Sun Set on Free Speech, N.Y. Times, Sept. 15, 1988, at A34, col. 1; Hysteria Dies Hard, L.A. Times, July 30, 1988, part II, at 8, col. 1; The McCarran-Walter Mischief, N.Y. Times, Sept. 5, 1986, at A26, col. 1; Turned Back in Toronto, Wash. Post, Apr. 29, 1985, at A10, col. 1; see also commentators noted in Note, First Amendment, supra note 29, at 160 n.86.

39. See supra note 29.

40. See Galvan v. Press, 347 U.S. 522, 530 (1954) (while upholding the deportation of a resident alien for membership in the Communist party (even though such membership was not a basis for deportation at the time of his membership), the Court, per Justice Frankfurter, stated: "[M]uch could be said for the view [that due process places some limitations on congressional power in this area] were we writing on a clean slate....") For further discussion of Galvan, see infra notes 105 108 and accompanying text; see also Harisiades v. Shaughnessy, 342 U.S. 580, 587 (1951) ("that aliens remain vulnerable to expulsion after long residence is a practice that bristles with severities").

41. For a discussion of the first amendment exception to plenary power deference, see infra notes 188-205 and accompanying text. For a discussion of efforts to evade the plenary power doctrine via statutory construction, see infra notes 209-227 and accompanying text. 
government," ${ }^{42}$ permitting "Congress regularly [to] make . . . rules that would be unacceptable if applied to citizens." 43

By legislative grace, Congress has recently provided that which the Court has been unwilling to require constitutionally. In 1987, Congress enacted section 901 of the Foreign Relations Authorization Act, Fiscal Years 1988 and $1989,{ }^{44}$ a one-year prohibition on ideological exclusion. In 1988, Congress extended the prohibition for two more years. ${ }^{45}$ The scope of that prohibition, however, is limited to nonimmigrant aliens, and it expressly excludes, inter alia, members of the Palestine Liberation Organization (PLO). ${ }^{46}$

\section{A. Ideological Exclusion under the McCarran-Walter Act}

In 1952, Congress passed the McCarran-Walter Act over President Truman's veto, ${ }^{47}$ codifying all existing immigration legislation and several new provisions in a comprehensive immigration statute called the Immigration and Nationality Act (INA). ${ }^{48}$ Prominent features of that Act, passed during the height of the "red scare," are sections 212(a)(27),

42. The plenary power doctrine applies to federal government treatment of aliens not only in the immigration context but in the domestic context as well. See Mathews v. Diaz, 426 U.S. 67 (1976) (rejecting equal protection challenge to denial of welfare benefits to resident aliens). By contrast, state treatment of aliens has been constrained by the fourteenth amendment since Yick Wo v. Hopkins, 118 U.S. 356 (1886), and accorded some form of heightened scrutiny since Graham v. Richardson, 403 U.S. 365, 376 (1970). This Comment specifically addresses only immigration issues, although federal domestic treatment of aliens is also implicated.

43. Mathews v. Diaz, 426 U.S. 67, 80 (1976), quoted with approval in Fiallo v. Bell, 430 U.S. 787, 792 (1977).

44. Pub. L. No. 100-204, § 901, 1987 U.S. Code Cong. \& ADmIN. News (101 Stat.) 1331, 1399-1400 (codified at 8 U.S.C. $\$ 1182$ note (Supp. V 1987)), discussed at infra notes $64-70$ and accompanying text.

45. Foreign Operations, Export Financing, and Related Programs Appropriations Act, 1989, Pub. L. No. 100-461, § 555, 1988 U.S. CodE CoNG. \& ADMIN. News (102 Stat.) 2268, 2268-36, discussed at infra notes $72-77$ and accompanying text.

46. For a list of all the exceptions to section 901 , see infra note 77.

47. "Seldom has a bill exhibited the distrust evidenced here for citizens and aliens alike." Public Papers of the Presidents of the United States: HarRy S. TRUman (1952-53) 441 (1961-66) (President's Message to Congress Vetoing the INA).

48. Pub. L. No. $82-414,66$ Stat. 163 (1952) (codified as amended at 8 U.S.C. $\S \S 1101-1557$ (1982)). 
(28), (29), ${ }^{49}$ and $241(\mathrm{a})(6),{ }^{50}$ containing the provisions designed to keep out "subversives." U1 Under these provisions, the primary bases for exclusion and deportation are membership in or affiliation with subversive organizations, and the teaching or advocacy of subversive doctrines. ${ }^{52}$

49. 8 U.S.C. $\$ 1182(a)(27)-(29)$ (1982). These are grounds of exclusion. See supra note 13. Subsections (27) and (29) authorize exclusion for reasons that are difficult to distinguish as either conduct or ideology. See infra note 52. Respectively, they authorize exclusion of

(27) Aliens who the consular officer or the Attorney General knows or has reason to believe seek to enter the United States solely, principally, or incidentally to engage in activities which would be prejudicial to the public interest, or endanger the welfare, safety, or security of the United States....

...

(29) Aliens [who would] ... (A) engage in activities which would be prohibited by the laws of the United States relating to espionage, sabotage, public disorder, or in other activity subversive to the national security, (B) engage in any activity a purpose of which is the opposition to, or the control or overthrow of, the Government of the United States, by force, violence, or other unconstitutional means, or (C) join, affiliate with, or participate in the activities of any organization which is registered or required to be registered under section 786 of title $50 \ldots$. .

8 U.S.C. $\S 1182(\mathrm{a})(27)$, (29) (1982).

INA $\S 212(a)(28)$ contains nineteen separate exclusion provisions, all of which are solely ideological. Examples include:

(A) Aliens who are anarchists;

(B) Aliens who advocate or teach, or who are members of or affiliated with any organization that advocates or teaches, opposition to all organized government;

(C) Aliens who are members of or affiliated with (i) the Communist Party of the United States . . . ;

(D) Aliens ... who advocate the economic, international, and governmental doctrines of world communism ....;

....

(F) ... Aliens who advocate or teach or who are members of or affiliated with any organization that advocates or teaches (i) the overthrow by force, violence, or other unconstitutional mcans of the Government of the United States or of all forms of law; or (ii) the duty, necessity, or propriety of the unlawful assaulting or killing of any officer or officers ... of the Government of the United States or of any other organized government, . . . or (iii) the unlawful damage injury, or destruction of property; or (iv) sabotage;

(G) Aliens who write or publish ... or who knowingly circulate, distribute, print, or display ... or who knowingly have in their possession for the purposes of circulation, publication, distribution, or display, any written or printed matter, advocating or teaching opposition to all organized government, or advocating or teaching (i) the overthrow by force, violence, or other unconstitutional means of the Government of the United States or of all forms of law; or (ii) the duty, necessity, or propriety of the unlawful assaulting or killing of any officer or officers ... of the Government of the United States or of any other organized government ... ; or (iii) the unlawful damage, injury, or destruction of property; or (iv) sabotage; or (v) the economic, international, and governmental doctrines of world communism or the establishment in the United States of a totalitarian dictatorship;

(H) Aliens who are members of or affiliated with any organization that writes, circulates, distributes, prints, publishes, or displays . . . any written or printed matter of the character described in subparagraph (G) ....

8 U.S.C. $\S 1182(\mathrm{a})(28)(1982)$.

50. 8 U.S.C. $\$ 1251(a)(6)$ (1982). These are grounds of deportation. They nearly identically mirror the grounds of exclusion. See supra notes $13 \& 49$.

51. These sections, in substantially identical form, were earlier contained in the Smith Act. Alien Registration Act of 1940, ch. 439, 54 Stat. 670.

52. In fact, these provisions cover both conduct and affiliation or advocacy, but in a way that is difficult to separate because of vague language that can encompass both conduct and expression. For example, section 212(a)(27)'s description of "activities which would be prejudicial to the public interest" and section 212(a)(29)'s description of "activity subversive to the national security" could 
These INA provisions, like their predecessors, which were used to exclude and deport alleged anarchists in the $1920 \mathrm{~s}^{53}$ and alleged members of the Commumist Party in the $1950 \mathrm{~s}^{54}$, have been broadly defined recently to exclude "subversive" leftists. ${ }^{55}$ The overwhelming majority of these exclusions had nothing to do with violence, but were based solely on the ideas that these aliens held and expressed, or on membership in ideologically unpopular organizations.

\section{B. Legislative Reform: Section 901}

Intense legislative, ${ }^{56}$ scholarly, ${ }^{57}$ and popular ${ }^{58}$ criticism has generated halting movement toward the legislative repeal of ideological exclusion. ${ }^{59}$ Movement away from ideological exclusion is extraordinarily difficult because it requires a balancing of sharply conflicting national

be used to deport either for "subversive" or "prejudicial" conduct or "subversive" or "prejudicial" expression. The vast majority of exclusions under these provisions, however, have been based purely on ideology, that is, expression and association. See supra note 37. For an illustration of the interplay of these grounds of exclusion, see Abourezk v. Reagan, 785 F.2d 1043, aff'd by an equally divided Court, 484 U.S. 1 (1987); see also Note, First Amendment, supra note 29, at 168-71.

53. See supra note 31 and accompanying text.

54. See, e.g., Shaughnessy v. United States ex rel. Mezei, 345 U.S. 206 (1953); Harisiades v. Shaughnessy, 342 U.S. 580 (1952); United States ex rel. Knauff v. Shaughnessy, 338 U.S. 537 (1950). For discussion of these cases, see S. LEgomSKY, IMMIGRATION AND THE JUDICIARY: LAW AND Politics in Britain AND AMERICA 199-204 (1987).

55. See Kleindienst v. Mandel, 408 U.S. 753 (1971), discussed at infra notes 89-100 \& 238-243; see also cases cited supra note 37.

56. See Hearings, Exclusion and Deportation of Aliens, supra note 32. The following statement by Rep. Steny Hoyer, Chairman of the Helsinki Commission, is indicative of legislative sentiment:

[T] he McCarran-Walter Act is the splinter in our eye-and other Helsinki signatories in fact try to make it into a beam.... Ours, by the way, is the only Helsinki signatory state that systematically excludes foreigners on the basis of their beliefs and affiliations as a formal statutory matter. Many view this as censorship. In my opinion it is. It has become ... an international embarrassment as well as, in my opinion, philosophically and intellectually unjustifiable.

Id. at 125 .

57. See supra note 29.

58. See supra note 38 .

59. The first legislative attempt to reform the ideological grounds of exclusion was the McGovern Amendment to the INA. Foreign Relations Authorization Act, Fiscal Year 1978, Pub. L. No. 95-105, Title I $\$ 112,91$ Stat. 844,848 (1979) (codified as amended at 22 U.S.C. $§ 2691$ (1982)). It allowed for a discretionary waiver of the ideological grounds of exclusion (for nonimmigrants only) if the Secretary of State believed that the alien did not present a risk to national security or the public welfare. The McGovern Amendment entailed a cumbersome and uncertain procedure to which many aliens refused to submit. See E. HuLl, WITHOut JUSTICE FOR ALL 74 (1985); Tilner, supra note 29 , at 72 n.528. Congress feared it presented a "loophole under which PLO agents could enter the United States." 125 CoNG. REC. 8345 (1979) (statement of Rep. Derwinski), and in 1979 it enacted an exception for members and officials of the PLO. Department of State Authorization Act, Fiscal Years 1980 and 1981, Pub.L.No. 96-60 § 109(2), 93 Stat. 395, $397-98$ (1979). It is the language of this PLO exception that is incorporated into section 901. See infra note 77.

For a more detailed discussion of the McGovern Amendment, see Note, First Amendment, supra note 29 , at $156-61$. 
impulses: commitment to an open society and freedom of expression on the one hand, ${ }^{60}$ and fear of unpopular or subversive groups and terrorism on the other. ${ }^{61}$

In spite of these obstacles, Representative Barney Frank, Senator Patrick Moynihan, and the Reagan Administration each submitted plans during the 100th Congress to amend the INA, including the ideological

- 60. Recommending passage of the Frank Amendment to the INA, entitled the Immigration Exclusion and Deportation Amendments of 1988, H.R. 4427, 100th Cong., 2d sess. (1988), the House Judiciary Committee stated:

These [ideological exclusion] provisions, which were enacted during the cold war era, and which deny entry to aliens, particularly communists, whose political beliefs may be unpopular, are anathema to the principles on which this nation was founded. ... Thus, the bill is needed not only to enhance the image of the United States in the international arena and to make U.S. policy regarding admission of aliens more consistent with our criticisms of other nations' human rights violations, but more importantly to protect the First Amendment association rights of persons in the United States by providing an open forum for debate, and ensuring access to the widest possible variety of foreign citizens and their ideas.

H.R. REP. No. 882, 100th Cong., 2d Sess. 16 (1988). This bill was not enacted into law, nor was its companion Senate bill, S. 2757, 100th Cong., 2d sess. (1988). Instead, section 901 was extended for two more years. See infra notes 70-72 and accompanying text.

61. The dissenting views of twelve Representatives are included in the Committee Report to the unenacted 1988 Frank Amendment. They state:

H.R. 4427, as amended by this Committee, does not adequately address the real and growing concerns involving terrorism, national security and intelligence. H.R. 4427 fails to exclude aliens who advocate or teach or who are affiliated with organizations that advocate the violent overthrow of the U.S. government. It also fails to exclude "immigrants" who are members of, or are affiliated with, the Communist Party, or any other totalitarian dictatorship. Both provisions are now a part of current law. (Section 212(a)(28))....

... The elimination of Section 212(a)(28) may allow the entry of individuals whose efforts, while present in this country, contribute to terrorist activities even though they may not direetly participate in such activities. What possible benefits could be obtained in allowing the entry of someone who is advocating the violent overthrow of our government as compared to the potential risks-i.e., possible solicitation of support, funds, resources and information for such activities that eventually lead to acts of terrorism?

H.R. ReP. No. 882, 100th Cong., 2d Sess. 118 (1988). 
exclusion provisions. ${ }^{62}$ No permanent legislation has yet been enacted, ${ }^{63}$ but there has been sufficient consensus on the need for reform to produce two successive temporary reforms. At the end of its first session, the 100th Congress passed section 901 of the Foreign Relations Authorization Act (FRAA), Fiscal Years 1988 and 1989. ${ }^{64}$ In its second session, Congress extended section 901 for two more years. ${ }^{65}$ Section 901 is divided into two subsections: section 901(a), prohibiting ideological exclusion, and section 901(b), entitled "Construction Regarding Excludable Aliens."

\section{Section 901(a): The Prohibition of Ideological Exclusion}

The 1987 version of section 901(a) prohibited the ideological exclusion of all aliens during 1988.66 It did not expressly repeal those sections of the INA which provide for ideological exclusion, however, but rather provided that,

no alien may be denied a visa, or excluded from admission into the

United States . . . or subject to deportation because of any past, current, or expected beliefs, statements, or associations which, if engaged in by a United States citizen in the United States, would be protected under the Constitution of the United States. ${ }^{67}$

62. The proposed Moynihan amendment would have repealed the current section 212(a)(28) ideological grounds of exclusion, see supra note 49 , and required a court order to deny entry for national security reasons, giving citizens standing to challenge any visa denied on political grounds. S. 28, 100th Cong., 1st Sess. (1987).

The Frank Amendment, as a part of simplifying and modernizing all grounds of exclusions, would have repealed sections 212(a)(27)-(29) and replaced them with grounds of exclusion for espionage, sabotage, criminal activity endangering public safety or national security, activity with a purpose to violently overthrow the U.S. government, and terrorist activity. H.R. 4427, 100th Cong., 2d Sess. (1988).

The Reagan administration's proposal would have repealed mere membership in the Communist Party as a ground for exclusion and narrowed the "advocacy" grounds, INA $\S 212(a)(28)$, to advocacy leading to certain acts of violence or terrorism. The bill also would have added a new ground for exclusion of aliens "whose entry could cause potentially serious adverse foreign policy consequences." H.R. 3293, 100th Cong., 1st Sess. (1987).

For a discussion of these proposals, see Scanlan, supra note 29, at 50; Helton, Reconciling the Power to Bar or Expel Alients on Political Grounds with Fairness and the Freedoms of Speech and Association: An Analysis of Legislative Proposals, 11 FoRdHAM INT'L L.J. 467 (1988).

63. See infra notes $70-72$ and accompanying text.

64. Pub. L. No. 100-204, $\S 901,1987$ U.S. Code Cong. \& Admin. News (101 Stat.) 1331, 1399-1400 (codified at 8 U.S.C. $\$ 1182$ note (Supp. V 1987)). For circumstances surrounding the bill's passage, see Greenhouse, The Law on 'Excludable Aliens': Stay Tuned, N.Y. Times, Jan. 1, 1988, at 36, col. 1; Helton, supra note 62, at 59.

65. Foreign Operations, Export Financing, and Related Programs Appropriations Act, 1989, Pub. L. No. 100-461 § 555, 1988 U.S. CODE CONG. \& ADMIN. NEwS (102 Stat.) 2268, 2268-36.

66. The legislation covered applications for visas submitted during 1988, admissions sought between 12/31/87 and $3 / 1 / 89$, and deportations based on activities occurring in 1988 or for which deportation proceedings were pending at any time during 1988. $\$ 901($ a), 1987 U.S. CoDE CoNG. \& ADMIN. NEWS (101 Stat.) at 1400.

67. Id., 1987 U.S. Code CoNG. \& AdmiN. News (101 Stat.) at 1399-1400. The standard 
Explaining its motivation for enacting section 901, the Conference Committee noted that because of ideological exclusion "the citizens of the United States have been denied the opportunity to have access to the full spectrum of international opimion, and the reputation of the United States as an open society, tolerant of divergent ideas, has suffered." 68 Therefore, section 901 was necessary

to make it clear that the United States is not fearful of foreign ideas or criticism or the individuals who espouse such ideas or advance such criticism ....

... [I]t is not in the interests of the United States to establish one standard of ideology for citizens and another for foreigners who wish to visit the United States. ${ }^{69}$

As conceived, section 901 was a temporary measure. Congress inserted a one-year sunset provision because it expected the House and Senate committees to produce comprehensive legislation permanently revising the grounds for ideological exclusion "early in the second session of the 100th Congress."70 The House Judiciary Committee eventually passed the comprehensive Frank Amendment but it never came to a floor vote. $^{71}$ Unable to pass the more thorough reform package, Congress did agree to extend the temporary reform for two additional years. ${ }^{72}$ The price of the extension, however, was a significant reduction in the provision's scope.

\section{Exceptions to Section 901}

The original section 901(a) applied to all aliens. ${ }^{73}$ In 1988, when Congress debated revising the section, Senator Alan Simpson argued that section 901 should be restricted to nonimmigrants. He stated: "I fully

applicable to U.S. citizens was established in Brandenburg v. Ohio, 395 U.S. 444 (1969). See infra note 297 for the Brandenburg test.

68. H.R. CONF. REP. No. 475, 100th Cong., 1st Sess. 163 (1987), reprinted in 1987 U.S. CODE CoNG. \& Admin. News 2314, 2424, and in 133 CoNG. REC. 11,343 (1987) [hereinafter CONFERENCE REPORT].

69. Id.

70. Id. at 165, 1987 U.S. CODE CONG. \& ADMIN. NEWS at 2426, 133 CONG. REC. at 11,344.

71. For the legislative history of the Frank Amendment, see H.R. 4427, 100th Cong., 2d Sess. (1988); 65 Interpreter Releases, No. 24, at 639-40 (June 27, 1988); 65 Interpreter Releases, No. 15, at 406 (Apr. 18, 1988); Helton, supra note 62.

72. The extension started out as Title IV of the Miscellaneous International Affairs Authorization Act of 1988, Senate Bill 2757, 100th Cong. 2d sess. (1988) and would have continued indefinitely. When it became clear that S. 2757 would not pass, the extension-then with a two-year sunset provision-was added at the last minute to a foreign aid appropriations bill, H.R. 4637, 100th Cong. 2d sess. (1988) and signed by the President on October 1, 1988. Foreign Operations, Export Financing, and Related Programs Appropriations Act, 1989, Pub. L. No. 100-461 § 555, 1988 U.S. Code Cong. \& Admin. News (102 Stat.) 2268, 2268-36. See Interpreter Releases (June 27, 1988), supra note 71; Interpreter Releases (Apr. 18, 1988), supra note 71.

73. The original section 901 provided that "[n]o alien shall be [excluded or deported for ideological reasons] . . . ." See supra note 67 and accompanying text. 
agree that we should not restrict the entry of visitors because of their beliefs, except when important foreign policy interests or national security interests are at stake. However, permanent immigrants, those who can become citizens, should receive closer scrutiny."74 Senator Simpson's view prevailed, and section 901 was amended so that only nonimmigrant aliens enjoy the same protection of expression and association that U.S. citizens enjoy. ${ }^{75}$

In addition to the provisions restricting coverage to nonimmigrant aliens, the 1988 version of the amendment retains several other express exceptions. Included in the exceptions to section 901(b) are Nazi war criminals, labor union officials from totalitarian states on official business, and asylum applicants who have persecuted others. ${ }^{76}$ Also

74. 134 Cong. Rec. S13,800 (daily ed. Sept. 30, 1988).

75. Foreign Operations, Export Financing, and Related Programs Appropriations Act, 1989, Pub. L. No. 100-461, § 555, 1988 U.S. CODE CONG. \& ADMIN. NEws (102 Stat.) 2268, 2268-36. The 1988 amendment added "nonimmigrant" to section 901(a) so it now provides that "[n]o nonimmigrant alien [shall be excluded for ideological reasons]. .." (emphasis added). For the full text of section 901, see supra text accompanying note 67. The amended section 901 thus does not apply to aliens already in the United States and admitted to permanent resident status (known as permanent resident aliens), or to aliens applying for permanent resident status from abroad or to aliens within the United States attempting to adjust status from nonimmigrant to immigrant. Section 901 as amended does, however, protect both nonimmigrant aliens traveling, working, or studying in the United States and those applying from abroad to do so.

The 1988 amendment also added minor technical clauses to section 901(b). These clauses are italicized in the text of section 901 (b) reprinted infra note 76.

76. The amended section 901(b) provides:

(b) Construction Regarding Excludable Aliens.-Nothing in this section shall be construed as affecting the existing authority of the executive branch to deport, to deny issuance of a visa to, to deny adjustment of status of, or to deny admission to the United States of, any alien-

(1) for reasons of foreign policy or national security, except that such deportation or denial may not be based on past, current, or expected beliefs, statements, or associations which, if engaged in by a United States citizen in the United States, would be protected under the Constitution of the United States, unless such alien is seeking issuance of a visa, adjustment of status, or admission to the United States as an immigrant;

(2) who a consular official or the Attorncy General knows or has reasonable ground to believe has engaged, in an individual capacity or as a member of an organization, in a terrorist activity or is likely to engage after entry in a terrorist activity; or

(3) who seeks to enter in an official capacity as a representative of a purported labor organization in a country where such organizations are in fact instruments of a totalitarian state. In addition, nothing in subsection (a) shall be construed as applying to an alien who is described in section 212(a)(33) of the Immigration and Nationality Act (relating to those who assisted in the Nazi persecutions), to an alien described in the last sentence of section 101(a)(42) of such Act (relating to those assisting in other persecutions) who is seeking the benefits of section 207, 208, 243(h)(1), or 245A of such Act (relating to admission as a refugee, asylum, witholding of deportation, and legalization, or to an alien who is described in section $2 l(c)$ of the State Department Basic Authorities Act of 1956. In paragraph (2), the term "terrorist activity" means the organizing, abetting, or participating in a wanton or indiscriminate act of violence with extreme indifference to the risk of causing death or serious bodily harm to individuals not taking part in armed hostilities.

Foreign Relations Authorization Act, Fiscal Years 1988 and 1989, Pub. L. No. 100-204, § 901(b), 
included in section 901(b) is an exception for "any alien who is a member, officer, official, representative or spokesman of the Palestine Liberation Organization" (the PLO exception). ${ }^{77}$

Whether or not these exceptions are wise or valid, Congress, by enacting section 901 , has provided by legislative grace what the Supreme Court has considered itself unable to demand-that the grounds for exclusion and deportation conform to constitutional protections. As such, Congress should be applauded for exercisnig its plenary power over imnigration to improve dramatically a system that was tarnishmg "the reputation of the United States as an open society, tolerant of divergent ideas."78

Nevertheless, the exceptions to section 901 reveal a hinited legislative tolerance of divergent ideas and, consequently, do not provide full assurance that U.S. citizens will be exposed to the full range of international opinion. The consequences of these exceptions are not nierely theoretical; rather, they have very real and drastic consequences for the lives of individuals such as Khader Hamide, Michel Shehadeh, ${ }^{79}$ Fouad Rafeedie, ${ }^{80}$ and their fanilies. The selective denial to sonie aliens of benefits generously granted to others is but a current niamfestation of a long history of immigration legislation which courts have held unreviewable for conformity with the Constitution. Thus, it is not surprising that Congress should grant to aliens in a spirit of noblesse oblige what U.S. citizens expect as an essential denıocratic right. Part II of this Coninient exanines the plenary power doctrine that has historically enabled the

1987 U.S. CODE CONG. \& ADMIN. News (101 Stat.) 1331, 1400 (codified at 8 U.S.C. § 1182 note (Supp. V 1987) (Prohibition on Exclusion or Deportation of Aliens on Certain Grounds)), amended by Foreign Operations, Export Financing, and Related Programs Appropriations Act, 1989, Pub. L. No. 100-461, § 555, 1988 U.S. CODE CONG. \& ADMIN. News (102 Stat.) 2268, 2268-36 (emphases added). The clauses italicized above in 901(b) and 901(b)(1) were added in the 1988 amendment. The PLO exception is italicized above in 901(b)(3).

77. The PLO is not mentioned by name in section 901(b). Rather, the PLO exception appears in section 901(b) as an exception for "an[y] alien who is described in section 21(c) of the State Department Basic Authorities Act of 1956 [22 U.S.C. § 2691(c)]." Pub. L. No. 100-204, § 901(b), 1987 U.S. CODE CONG. \& ADMIN. NEws (101 Stat.) 1331, 1400 (codified at 8 U.S.C. $\$ 1182$ note (Supp. V 1987)), quoted at supra note 76 (italicized clause in 901(b)(3)). Section 21 of the State Department Basic Authorities Act is the 1977 McGovern Amendment, discussed supra note 59. Section 21(c) is the 1979 amendment to the McGovern Amendment which states in part: "This section does not apply with respect to any alien who is a member, officer, official, representative or spokesman of the Palestine Liberation Organization." Pub. L. No. 96-60, § 109(2), 93 Stat. 395, $397-98$ (1979) (codified at 22 U.S.C. § 2691(c) (1982)).

78. Conference RePort, supra note 68, at 163, 1987 U.S. Code Cong. \& ADMin. News at 2424.

79. See ADC v. Meese, 714 F. Supp. 1060 (C.D. Cal. 1989), discussed supra notes $19-26$ and accompanying text.

80. See Rafeedie v. INS, 688 F. Supp. 729 (D.D.C. 1988), discussed supra notes 8-17, 25 and accompanying text. 
courts to avoid reviewing the immigration-related acts of Congress and the executive.

II

\section{PlenaRy POWER}

Before a court can entertain a first amendment challenge to the exceptions to section 901, it must first confront the plenary power doctrine, which denies the judiciary the power to review the constitutionality of immigration legislation. This obstacle may be overcome by demonstrating either that the plenary power doctrine is no longer viable and should be abandoned, or, more modestly, that it does not apply to first amendment challenges. Thus, before this Comment presents specific challenges to the resident alien ${ }^{81}$ and $\mathrm{PLO}^{82}$ exceptions to section 901, it takes a preliminary detour through the plenary power doctrine.

After a brief description of the plenary power doctrine, this Part reviews several different categorical attacks on plenary power that have been made by legal scholars. Taken together, the criticisms provide compelling support for abandoning the doctrine. The next section discusses certain indications that the Supreme Court is finally preparing to inove away from total deference in immigration matters. The final section argues alternatively and more modestly that existing case law supports a first amendment exception to the plenary power doctrine. At least one of these arguments is necessary, but either is sufficient to allow the first amendment challenges presented in Parts III and IV to proceed.

\section{A. Description}

Justice Frankfurter graphically described the plenary power doctrine in his concurring opinion in Harisiades v. Shaughnessy: ${ }^{83}$

The conditions for entry of every alien [and] the particular classes of aliens that shall be denied entry altogether... [are] matters solely for the responsibility of the Congress and wholly outside the power of this Court to control.

... [W] hether immigration laws have been crude and cruel, whether they may have reflected xenophobia in general or anti-Semitism or antiCatholicism, the responsibility belongs to Congress. ${ }^{84}$

81. Discussed at infra notes $296-354$ and accompanying text.

82. Discussed at infra notes $355-429$ and accompanying text.

83. 342 U.S. 580 (1952) (upholding the deportation of long-term resident aliens for previous membership in the Communist Party even though their membership had terminated before the 1940 Alien Registration Act made such membership a deportable offense).

84. Id. at 596-97 (Frankfurter, J., concurring). For discussion of the impact of nativism and xenophobia on immigration policy, see E. HuLL, supra note 59, at 1-28; Schuck, supra note 13, at 3; Tilner, supra note 29, at 37-51; Sherman, The Immigration Laws and the "Right to Hear" Protected by Academic Freedom, 66 TEx. L. REv. 1547, 1550-51 (1988). For a discussion of American 
An even pithier statement, found in United States ex rel. Knauff $v$. Shaughnessy, ${ }^{85}$ reveals that, at its height, the plenary power doctrine encompassed even procedural due process: "Whatever the procedure authorized by Congress is, it is due process as far as an ahen denied entry is concerned." 86

The plenary power doctrine has disabled courts from intervening in cases of ideological exclusion ${ }^{87}$ since at least 1904, when the Court in United States ex. rel. Turner v. Williams ${ }^{88}$ upheld the deportation of a

nativism and xenophopia, see T. CURRAN, XENOPHOBIA AND IMMIGRATION, 1820-1930 (1975); J. Higham, supra note 31; M. Levin, Political Hysteria in AMerica: The Democratic CAPACITY FOR REPRESSION (1971).

85. 338 U.S. 537 (1950) (upholding the exclusion of the alien wife of a returning U.S. citizen soldier without a hearing and on the basis of undisclosed information). For further discussion of this case, see S. LEgomSKy, supra note 54, at 200-01; Frank, The United States Supreme Court: 1949-50, 18 U. CHI. L. REv. 1, 21-23 (1950).

86. Knauff, 338 U.S. at 544 (citing Nishimura Ekiu v. United States, 142 U.S. 651, 659-60 (1892) and Ludecke v. Watkins, 335 U.S. 160 (1948)). The Court quoted this statement with approval in Shaughnessy v. United States ex rel. Mezei, 345 U.S. 206, 212 (1953) (upholding the exclusion without a hearing of a long-term permanent resident alien and his indefinite detention on Ellis Island). Martin, Due Process and Membership in the National Community: Political Asylum and Beyond, 44 U. PITT. L. REv. 165 (1983), reports the eventual fate of these two aliens: "A combination of public and congressional pressure, followed by a favorable decision of the [Board of Immigration Appeals], ultimately resulted in Ellen Knauf's admission after three years of litigation. ... Similar actions led to Mezei's release after four years' incarceration ...." Id. at 173 n.23; see also id. at 167-77 (discussing "Knauff-Mezei" doctrine).

As these two statements indicate, the plenary power doctrine applies to both substantive classifications and procedural questions. However, in other cases the Court has distinguished the procedural due process rights of aliens not admitted from those of resident aliens. In the context of deportation and exclusion of resident aliens, the minimum protections of due process apply. See, e.g., Landon v. Plasencia, 459 U.S. 21, 32-37 (1982) (returning resident alien entitled to a due process hearing in exclusion proceedings); Kwong Hai Chew v. Colding, 344 U.S. 590, 596-97 (1953) (although never reaching the constitutional issue, stating that due process prohibits detention and exclusion of a resident alien without a hearing). The amount of due process protection available to a returning resident alien in exclusion proceedings remains ambiguous, however. See Rafeedie v. INS, 688 F. Supp. 729, 743-51 (D.D.C. 1988), discussed supra notes 8-17, 25 and accompanying text.

87. The plenary power doctrine can be characterized in two corollary yet discrete ways. First, constitutional protections do not constrain the Congress or the executive in the immigration area. This is the extraconstitutionality aspect of plenary power. Second, the Courts will not review congressional or executive action for constitutional conformity. This is the judicial deference aspect of plenary power. These two aspects are root and branch of the plenary power doctrine. For purposes of economy, this Comment will focus on the judicial deference aspect of plenary power. The issue, however, is not simply the availability and appropriateness of judicial review, but, more accurately, whether the Constitution constrains Congress and the executive in immigration matters and whether the courts can enforce those constraints.

Congress and the executive branch can, of course, choose voluntarily to comply with constitutional constraints. Even in immigration matters they frequently do so. Except for the exceptions being discussed in this Comment, section 901 itself is such an example. Yet Congress has often blatantly ignored constitutional constraints-especially in times of political or racial intolerance-as the ideological exclusion provisions amply indicate. See supra notes 47-55 and accompanying text. The issue, then, is whether the courts will act to enforce constitutional constraints in the area of immigration as they do in others.

88. 194 U.S. 279 (1904). The opinion, relying with little discussion on the carly cases cited 
resident alien anarchist. The reluctance to intervene continues today. Kleindienst v. Mandel, ${ }^{89}$ the most recent Supreme Court case to treat ideological exclusion, invoked the plenary power doctrine to uphold the denial of a visa to a Belgian academic Marxist invited to the United States for a lecture tour. ${ }^{90}$

Furthermore, Fiallo v. Bell, ${ }^{91}$ the most recent Supreme Court case to consider a constitutional challenge to a substantive immigration classification, ${ }^{92}$ demonstrates that the plenary power doctrine continues to dominate immigration law generally. In Fiallo, the Court upheld an immigration statute which treated the illegitimate children of immigrating fathers more harshly than those of immigrating mothers. Yet, on that same day, the Court decided Trimble v. Gordon, ${ }^{93}$ holding that similar discrimination, in the domestic context of state intestate succession statutes, violates the equal protection clause. This discrepancy graphically illustrates the plenary power doctrine at work. ${ }^{94}$ The Fiallo Court

infra at notes 101-104, held that even a statute excluding aliens who were anarchist "political philosophers innocent of evil intent" would withstand a first amendment challenge. 194 U.S. at 294.

89. 408 U.S. 753 (1972). The Court refused to weigh the facial legitimacy of the visa denial against the conceded injury to the co-plaintiff U.S. citizens deprived of their first amendment right to receive ideas. For a reading of $M$ andel suggesting less deference by the Court, see infra notes 221243 and accompanying text.

90. The Court strongly reaffirmed its deference to Congress' plenary power: " 'Over no conceivable subject is the legislative power of Congress more complete than it is over' the admission of aliens." 408 U.S. at 766 (quoting Oceanic Navigation Co. v. Stranahan, 214 U.S. 320, 339 (1909)). The Mandel Court concluded:

[W] hen the Executive exercises this [plenary immigration] power negatively on the basis of a facially legitimate and bona fide reason, the courts will neither look behind the exercise of that discretion, nor test it by balancing its justification against the First Amendment interests of those who seek personal communication with the applicant.

Id. at 770 .

Mandel involved the denial of a visa to Ernest Mandel, a Belgian citizen and self-described academic, nonviolent, "revolutionary Marxist," then editor-in-chief of the Belgian left socialist weekly La Gauche. Mandel had been invited by U.S. universities to lecture and participate in conferences. Id. at 756-57.

In the domestic context, the Court has characterized aliens as "a prime example of a "discrete and insular minority'... for whom heightened judicial solicitude is appropriate." Graham v. Richardson, 403 U.S. 365, 372 (1971) (quoting United States v. Carolene Products, 304 U.S. 144, 152-53 n.4 (1938)). Thus, the Graham Court accorded state classifications based on alienage as "inherently suspect and subject to close scrutiny," Id. at 376. This contrasts sharply with cases like Mathews v. Diaz, 426 U.S. 67 (1976), where the Court made clear that, for the federal government, the plenary power doctrine applies inside the country as well as at the borders. Id. at 77-87 (rejecting equal protection challenge to denial of Medicare eligibility to aliens not admitted for permanent residence and not residents for at least five years because the classifieation was not "wholly irrational"). See supra note 42.

91. 430 U.S. 787 (1977).

92. The more recent case of INS v. Chadha, 462 U.S. 919 (1983), discussed at infra notes 174183 and accompanying text, involved judicial review of immigration legislation but not of legislation distinguishing one group of aliens from another group of aliens or from citizens for purposes of admission, deportation, exclusion, or other treatment.

93. 430 U.S. 762 (1977).

94. For more discussion of these two cases, see S. LEGOMSKY, supra note 54, at 206-08. 
readily acknowledged that in the immigration context, " "Congress regularly makes rules that would be unacceptable if applied to citizens." "95 The Court refused to review the underlying policy distinction because it had no "judicial authority to substitute [its] political judgment for that of the Congress" in "policy questions entrusted exclusively to the political branches of [the] Government." 96

\section{B. The Critique of the Plenary Power Doctrine}

The holdings and language of Mandel, Mathews, and Fiallo demonstrate that the plenary power doctrine is alive and well. This doctrine has been thoroughly discussed and broadly condemned in the academic literature. ${ }^{97}$ It is beyond the scope of this Comment to engage in yet another thorough analysis of the doctrine. Instead, this section briefly suminarizes the existing critiques to support the argument that the plenary power doctrine should not preclude judicial review of section 901 .

Coinmentators-and dissenting judges ${ }^{98}$ - have made widely ranging assaults on the legitimacy of the plenary power doctrine. Their criticisms can be roughly broken down into the following general charges:

95. Fiallo, 430 U.S. at 792 (quoting Mathews v. Diaz, 426 U.S. 67, 80 (1976)).

96. Id. at 798.

97. Commentary criticizing the plenary power doctrine includes Henkin, The Constitution and United States Sovereignty: A Century of Chinese Exclusion and its Progeny, 100 HARv. L. REv. 853, 858-63 (1987) [hereinafter Henkin, Chinese Exclusion]; Henkin, The Constitution as Compact and as Conscience: Individual Rights Abroad and at our Gates, 27 WM. \& MARY L. REv. 11, 25-34 (1985) [hereinafter Henkin, Constitution as Compact]; Legomsky, Immigration Law and the Principle of Plenary Congressional Power, 1984 SUP. CT. REv. 255 [hereinafter Legomsky, Plenary Power]; S. LEGOMSKY, supra note 54, at 177-222; Schuck, supra note 13; Note, Constitutional Limits, supra note 29; Comment, The Constitutional Rights of Excludable Aliens: History Provides a Refuge, 61 WASH. L. REv. 1449 (1986) (authored by Tamara Conrad).

Further discussion of the plenary power doctrine is found in commentary discussing particular aspects of immigration policy rendered unreviewable by the plenary power doctrine. See, e.g., Hart, The Power of Congress to Limit the Jurisdiction of Federal Courts: An Exercise in Dialectic, 66 HARv. L. REv. 1362, 1387-96 (1953); Scanlan, supra note 29, at 1499-1511; Shapiro, supra note 29; Voigt, supra note 29.

98. The plenary power doctrine has generated powerful dissents throughout the entire history of its existence. See, e.g., Fong Yue Ting v. United States, 149 U.S. 698, 737 (1893) (Brewer, J., dissenting) ("Where are the limits to such powers to be found, and by whom are they to be pronounced? Is it within legislative capacity to declare the limits? If so, then the mere assertion of an inherent power creates it, and despotism exists."); Harisiades v. Shaughnessy, 342 U.S. 580, 598 (1952) (Douglas J., dissenting) ("The view that the power of Congress to deport aliens is absolute and may be exercised for any reason which Congress deems appropriate ... seems to me to be inconsistent with the philosophy of constitutional law which we have developed for the protection of resident aliens."); Shaughnessy v. United States ex rel. Mezei, 345 U.S. 206, 226 (1953) (Jackson, J., dissenting) ("Does the power to exclude mean that exclusion may be continued or effectuated by any means which happen to seem appropriate to the authorities?"); Jean v. Nelson, 472 U.S. 846, 874 (1985) (Marshall J., dissenting) ("Only the most perverse reading of the Constitution would deny detained aliens the right to bring constitutional challenges to the most basic conditions of their confinement."); see also infra note 115 (Justice Brewer); infra text accompanying. notes 134-135 (Justice Douglas). 
(1) the early case authority upon which courts rely does not actually establish or support judicial deference in immigration matters; (2) the courts' proffered substantive rationales do not support the doctrine; and (3) the doctrine violates constitutionally mandated judicial responsibility and betrays constitutional values. This Comment summarizes each of these criticisms in turn.

\section{The Early Case Authority}

Professor Stephen Legomsky, in Immigration and the Judiciary,99 carefully analyzes the cases upon which courts have consistently relied for statements of their role in reviewing immigration matters. ${ }^{100}$ These early cases-The Chinese Exclusion Case, ${ }^{101}$ Nishimura Ekiu v. United States, ${ }^{102}$ and Fong Yue Ting v. United States ${ }^{103}$-are crucial to the continuing validity of the plenary power doctrine for two related reasons. First, many immigration opinions simply cite the cases as bare precedent without reviewing or questioning their rationales. ${ }^{104}$ Second, Justice

99. S. LEGOMSKY, supra note 54, at 184-96. This book builds on his earlier work in Legomsky, Plenary Power, supra note 97.

100. See, e.g., Kleindienst v. Mandel, 408 U.S. 753 (1971), where the Court stated,

In accord with ancient principles of the international law of nation-states, the Court in The

Chinese Exclusion Case and in Fong Yue Ting v. United States held broadly, as the Government describes it, that the power to exclude aliens is "inherent in sovereignty, necessary for maintaining normal international relations and defending the country against foreign encroachments and dangers-a power to be exercised exclusively by the political branches of government ...." Since that time, the Court's general reaffirmations of this principle have been legion.

Id. at 765-66 (citations omitted); see also Legomsky, Plenary Power, supra note 97, at 289 n.174.

101. 130 U.S. 581 (1889), aff'g In re Chae Chan Ping, 36 F. 431 (C.C.N.D. Cal. 1888). The official designation of the case in the United States Reports as The Chinese Exclusion Case exemplifies the ethnocentric nature of the legal and political culture of this country at the time the Court was formulating the plenary power doctrine: contempt for Asians extended to refusing to learn or use their names. The deportation of Kaorn Yamataya, which the Court upheld in The Japanese Immigrant Case, 189 U.S. 86 (1903), is yet another example. The contempt extended even further. Justice Brewer, a member of the majority in The Chinese Exclusion Case, later minimized the importance of that case since the statute upheld by the Court (authorizing deportation of Chinesc aliens) had been "directed only at the obnoxious Chinese," whom he described as a "distasteful class." Fong Yue Ting v. United States, 149 U.S. 698, 743 (1893) (Brewer, J., dissenting). Thus, a proper regard for the dignity of the aliens involved in those cases suggests abandoning this customary but offensive sobriquet. See Matsuda, Public Response to Racist Speech: Considering the Victim's Story, 87 Mich. L. REV. 2320, 2329 n.49. However, in spite of its xenophobic undercurrents this Comment will continue to use The Chinese Exclusion Case as a case name, not only to conform to standard usage, but also as a reminder of the racism on which the Court built the plenary power doctrine.

102. 142 U.S. 651 (1892) (upholding exclusion of an entering alien on grounds that she was likely to become a public charge against a challenge that duc process required judicial determination of the facts upon which exclusion was based).

103. 149 U.S. 698 (1893) (upholding, against a due process claim, the deportation of a resident alien, unable to provide a Caucasian witness to testify to his longtime residence in the United States).

104. For example, as early as 1895 , the first Justice Harlan could state categorically:

The power of Congress to exclude aliens altogether from the United States, or to prescribe the terms and conditions upon which they may come to this country, and to have 
Frankfurter's declaration in Galvan v. Press ${ }^{105}$ that the Court is unquestioningly bound to these early cases has itself been relied upon so frequently that it has become independent authority for the plenary power doctrine. ${ }^{106}$

In Galvan the Court held that a person may be deported for membership in the Communist Party without proving that person's "support, or even deinonstrated knowledge, of the Communist Party's advocacy of violence."107 Justice Frankfurter, writing for the Court, went on to say:

[M] uch could be said for the view, were we writing on a clean slate, that the Due Process Clause qualifies the scope of political discretion heretofore recognized as belonging to Congress in regulating the entry and deportation of aliens. . . But the slate is not clean. As to the extent of the power of Congress under review, there is not merely "a page of history," . . . but a whole volume. . . . [T] [Tat the formulation of these policies is entrusted exclusively to Congress has become about as firmly embedded in the legislative and judicial tissues of our body politic as any aspect of our government. ... We are not prepared to deem ourselves wiser or more sensitive to human rights than our predecessors, especially those who have been most zealous in protecting civil liberties under the Constitution, and must therefore under our constitutional system recognize congressional power dealing with aliens. ... ${ }^{108}$

Legomsky deinonstrates that, regardless of its predecessors' wisdom and sensitivity to human rights, the Court's reliance on these early cases is inisplaced. In fact, analysis of their holdings and rationales shows that the early cases provide no support for the plenary power doctrine. ${ }^{109}$ The Chinese Exclusion Case, "the foundation of our constitutional jurisprudence concerning immigration," 110 does not establish or support the plenary power doctrine. The Chinese Exclusion Case does not even treat the relationship between Congress and the judiciary. Rather, it focuses on the federal government's iminigration power in relation to the

its declared policy in that regard enforced exclusively through executive officers, without judicial intervention, is settled by our previous adjudications.

Lem Moon Sing v. United States, 158 U.S. 538, 547 (1895). Eight decades later, the Court quoted Justice Harlan with approval. See Mandel, 408 U.S. at 766.

105. 347 U.S. 522 (1954).

106. S. LEGOMSKY, supra note 54, at 218. Subsequent cases relying on Frankfurter's statement include Mandel, 408 U.S. at 766-67; Fiallo v. Bell, 430 U.S. 787, 795 n.6 (1977); Rafeedie v. INS, 688 F. Supp. 729, 742 (D.D.C. 1988).

107. 347 U.S. at 527.

108. Id. at $530-32$ (citation omitted).

109. Professor Henkin makes the same argument in Henkin, Chinese Exclusion, supra note 97, at 858 .

110. Henkin, Constitution as Compact, supra note 97, at 26. 
states $^{111}$ and other countries. ${ }^{112}$ The Chinese Exclusion Case holds that federal immigration power preempts state authority to control immigration and that this federal power is not constrained by treaty. Only in this context of federalism and international relations, not as a matter of the separation of powers, does The Chinese Exclusion Case hold that federal immigration power is "plenary."

The Chinese Exclusion Case established that federal power over immigration, although not constitutionally delegated, is inherent in national sovereignty. ${ }^{113}$ As such, The Chinese Exclusion Case is a classic exercise in judicial review. The Court reviewed the case of an alien who challenged her deportation, claiming that Congress had no power to enact the deportation statute and that the statute was in violation of treaty. After analyzing both claims, the Court held that the legislation was valid. This holding that Congress has the power to enact such a statute is no less an exercise of judicial review than a holding that Congress does not have the power. The Chinese Exclusion Case does not say, nor does its rationale imply, that courts are incapable of reviewing immigration legislation for constitutional validity. ${ }^{114}$ In fact the court recognized that the implicit sovereign federal power to regulate immigration was subject to constitutional limitations: "The powers to declare war ... and admit subjects of other nations to citizenship, are all sovereign powers, restricted in their exercise only by the Constitution itself . . . "115

Legomsky acknowledges that the later seminal cases did indeed

111. The implied immigration power that the Court articulated in The Chinese Exclusion Case, 130 U.S. 581 (1889), was an incident of sovereignty "belonging to the government of the United States," Id. at 609 (emphasis added), and not exclusively to the legislative or executive branches. Obviously, "the government of the United States" includes thc judicial branch. In this regard The Chinese Exclusion Case is merely an extension of The Head Money Cases, 112 U.S. 580 (1884), which established that the commerce clause and the need for national uniformity in immigration matters preempts state power to regulate immigration.

112. See The Chinese Exclusion Case, 130 U.S. at 600 (treaty with China did not limit Congress' power to exclude aliens).

113. "The power of exclusion of foreigners being an incident of sovereignty[,] . . [i]t cannot be granted away or restrained on behalf of any one." Id. at 609.

114. The Court stated that the congressional decision to exclude these aliens was "conclusive upon the Judiciary." Id. at 606. Properly understood, the statement "meant only that the Court could not interfere because Congress had done nothing unconstitutional" as determined by the Court through the process of judicial review. S. LEGoMSKY, supra note 54, at 193.

115. The Chinese Exclusion Case, 130 U.S. at 604 . A later opinion of Justice Brewer, a member of The Chinese Exclusion Case majority, provides further evidence that The Chinese Exclusion Case did not place the federal immigration power outside the scope of constitutional judicial review. In his dissent in Fong Yue Ting v. United States, 149 U.S. 698 (1893), Justice Brewer stated:

It is said that the power here asserted is inherent in sovereignty. This doctrine of powers inherent in sovereignty is one both indefinite and dangerous. Where are the limits to such powers to be found, and by whom are they to be pronounced? Is it within legislative capacity to declare the limits? If so, then the mere assertion of an inherent power creates it, and despotism exists. . . The governments of other nations have elastic powers-ours is fixed and bounded by a written constitution.

Id. at 737 (Brewer, J., dissenting). 
practice judicial deference in immigration matters, although he notes that they did so with summary reliance upon The Chinese Exclusion Case, either without independent analysis of their own, or with faulty analysis. ${ }^{116}$ A close examination of the early cases compels the conclusion that, with his "clean slate" statement, Justice Frankfurter took a house of cards and cast it into concrete. ${ }^{117}$ Had the Court exercised the same timidity towards Plessy v. Ferguson ${ }^{118}$ that it has exercised towards The Chinese Exclusion Case, Nishimura Ekiu v. United States, ${ }^{119}$ and Fong Yue Ting v. United States, ${ }^{120}$ much of this nation's proudest constitutional adjudication would never have been written.

\section{The Rationales}

The lack of sound precedential support for the plenary power doctrine would not be so significant if the current rationales offered to support its hegemony were adequate. Several commentators have demonstrated that they are not. ${ }^{121}$ The four primary rationales offered in support of the plenary power doctrine may be abbreviated as follows: (1) the right versus privilege distinction; (2) the Constitution's lack of effect

116. For example, Fong Yue Ting held that due process of law was not required in a deportation proceeding because an order of deportation is not punitive and the deported alien had "not, therefore been deprived of life, liberty or property." 149 U.S. at 730 . But as Legomsky points out, "categorization of a particular disability as punishment is not now, and was not then, an essential element of a due process claim." S. LEGomSKY, supra note 54, at 196 (footnotes omitted).

117. Professor Martin points out that this solicitude for precedent despite changing circumstances and mores is not only inconsistent with Supreme Court practice in other areas but with other statements issued by Justice Frankfurter as well. Martin, supra note 86, at 235 . For prominent examples of inconsistency with Supreme Court practice, see Brown v. Board of Educ., 347 U.S. 483 (1954) (overturning the "separate but equal" doctrine of Plessy v. Ferguson, 163 U.S. 537 (1896)); Shaffer v. Heitner, 433 U.S. 186, 211-12 (1977) (overturning the firmly established distinction between in rem and in personam jurisdiction). Frankfurter's concurring opinion in Graves v. New York ex rel. O'Keefe, 306 U.S. 466 (1939), demonstrates the inconsistency among his own statements. There, Frankfurter joined the Court in overturning a long line of cases concerning intergovernmental tax immunities. The Justice stated:

[There has been a] tendency to encrust unwarranted interpretations upon the Constitution and thereafter to consider merely what has been judicially said about the Constitution, rather than to be primarily controlled by a fair conception of the Constitution. . . . [T] ultimate touchstone of constitutionality is the Constitution itself and not what we have said about it.

Id. at 491-92 (Frankfurter, J., concurring).

Furthermore, in light of Dred Scott v. Sandford, 60 U.S. (19 How.) 393 (1857), Plessy, and The Chinese Exclusion Case itself, it is difficult to accept wholeheartedly Frankfurter's characterization of his predecessors as "those who have been most zealous in protecting civil liberties under the Constitution." Galvan v. Press, 347 U.S. 522, 531-32 (1954).

118. 163 U.S. 537 (1896), overruled, Brown v. Board of Educ., 347 U.S. 483 (1954).

119. 142 U.S. 651 (1892).

120. 149 U.S. 698 (1893).

121. See, e.g., S. LEGomSky, supra note 54, at 301-24; Legomsky, Plenary Power, supra note 97, at 260-78; Note, Constitutional Limits, supra note 29, at 966-83. 
outside of the United States; (3) the inherent sovereign power over foreign affairs; and (4) the doctrines of political question and deference in foreign affairs. A brief examination of each of these demonstrates their inadequacy as support for the plenary power doctrine.

\section{a. The Right Versus Privilege Distinction}

The right versus privilege distinction refers to the principle that admission to the United States is not a right but a privilege. ${ }^{122}$ The principle that people do not have "rights" when accorded a privilege has been discredited in other contexts. ${ }^{123}$ To state that "[i]t is clear that Mandel personally, as an unadmitted and nonresident alien, had no constitutional right of entry to this country as nonimmigrant or otherwise" 124 is obviously true. That statement, however, begs the critical question: Given that we do admit aliens, must we conduct the admissions process according to standards articulated in the Constitution? There is neither logic nor morality in the proposition that, simply because the government need not admit aliens at all, it can therefore disregard constitutional constraints in their admission and subsequent treatment. $^{125}$

122. In United States ex rel. Knauff v. Shaughnessy, 338 U.S. 537 (1950), the Court reasoned that "admission of aliens to the United States is a privilege granted by the sovereign United States Government. Such privilege is granted to an alien only upon such terms as the United States shall prescribe. It must be exercised in accordance with the procedure which the United States provides." Id. at 542 .

123. See, e.g., Sherbert v. Verner, 374 U.S. 398, 404 (1963) ("Nor may the South Carolina court's construction of the statute be saved from constitutional infirmity on the ground that unemployment benefits are not appellants 'right' but merely a 'privilege." "); see also Board of Regents v. Roth, 408 U.S. 564, 571 \& n.9 (1972); Goldberg v. Kelly, 397 U.S. 254, 262 (1970); Wieman v. Updegraff, 344 U.S. 183, 192 (1952); French, Unconstitutional Conditions: An Analysis, 50 Geo L.J. 234 (1961); Van Alstyne, The Demise of the Right-Privilege Distinction in Constitutional Law, 81 HaRV. L. REV. 1439 (1968).

124. Kleindienst y. Mandel, 408 U.S. 753, 762 (1972).

125. For further critique of this rationale, see S. LEGOMSKY, supra note 54, at 315-17; Legomsky, Plenary Power, supra note 97, at 270; Note, Constitutional Limits, supra note 29, at 97577. 


\section{b. Extraterritoriality}

The theory that the Constitution does not constrain the U.S. government's actions abroad ${ }^{126}$ is equally anachronistic. ${ }^{127}$ The plurality stated this well in Reid v. Covert:

[W]e reject the idea that when the United States acts against citizens abroad it can do so free of the Bill of Rights. The United States is entirely a creature of the Constitution. Its power and authority have no other source. It can only act in accordance with all the limitations imposed by the Constitution. ${ }^{128}$

There is no principled basis to conclude that, though the Constitution authorizes Congress to exercise its extraterritorial power, ${ }^{129}$ the Constitution does not concomitantly constrain that power. ${ }^{130}$

\section{c. Inherent in Sovereignty}

The most prominent, yet most inadequate, rationale offered in support of the plenary power doctrine since its inception ${ }^{131}$ is that the powers of Congress and the executive over immigration are "inherent in

126. This rationale relates only to the exercise of visa denial (exclusion) of citizens applying from abroad. As to them, the government is acting extraterritorially. This rationale is hinted at in United States ex rel. Turner v. Williams, 194 U.S. 279 (1904), where the Court stated: "[T]hose who are excluded cannot assert the rights in general obtaining in a land to which they do not belong as citizens or otherwise." Id. at 292 . Such reasoning can only support judicial deference to the political branches in their treatment of aliens who are actually outside of the country. Courts have often applied the plenary power doctrine more broadly, however, to countenance deportation of even resident aliens. See supra notes $19-22$ and accompanying text.

127. The Court decided Turner, discussed at supra note 126, in the shadow of In re Ross, 140 U.S. 453 (1891), where the Court had stated baldly, "The Constitution can have no operation in another country." Id. at 464 . The validity of such a rationale today is clearly eliminated by the holding of Reid v. Covert, 354 U.S. 1 (1957) (requiring constitutional protections to be applied to the trial abroad of civilian dependents of military personnel), which overruled Ross, calling it a "relic from a different era." Id. at 12 (plurality opinion).

The Ninth Circuit recently reiterated this concept in United States v. Verdugo-Urquidez, 856 F.2d 1214 (1988) (affirming the suppression of evidence seized by DEA agents in violation of the Fourth Amendment from the defendant's home in Mexico), cert. granted, 109 S.Ct. 1741 (1989) (No. 88-1353). The Ninth Circuit stated, "The Constitution imposes substantive constraints on the federal government, even when it operates abroad." Id. at 1218.

128. 354 U.S. I, 5-6 (1957) (plurality opinion per Black, J.) (footnotes omitted).

129. For the power of the federal government to conduct foreign affairs, see United States v. Curtiss-Wright Export Corp., 299 U.S. 304, 315-19 (1936).

130. As Professor Legomsky argues,

Since federal power derives from the Constitution, it is contradictory to uphold a statute having extraterritorial effect but to deny that its application is subject to constitutional limitations. If the Constitntion is read to empower federal officials to act outside American territory, then it is not apparent why it should be interpreted as inapplicable for the purpose of limiting such action.

Legomsky, Plenary Power, supra note 97, at 275; see also S. LEGOMSKY, supra note 54, at 321-23; Note, Constitutional Limits, supra note 29, at 978-83.

131. The Chinese Exclusion Case, 130 U.S. 581, 603-04 (1889) ("Jurisdiction over its own territory to [the extent of excluding aliens] is an incident of every independent nation. It is a part of its independence."). 
sovereignty."132 It is debatable whether the power over immigration is appropriately grounded in an unenumerated power implicit only in the inherent sovereignty of a nation. ${ }^{133}$ However, what is peculiar about the "inherent in sovereignty" rationale is that, by itself, it is not a rationale at all for a doctrine of judicial deference. It leaves unexplained the primary issue in plenary power-even if the federal immigration power is inherent, is it perforce also absolute, in other words, beyond constitutional restraint?

In his dissent in Harisiades v. Shaughnessy, ${ }^{134}$ Justice Douglas pointedly noted the anomaly of the "inherent in national sovereignty" basis for unreviewable power, stating: "The power of deportation is . . . an implied one. The right to life and liberty is an express one. Why this implied power should be given priority over the express guarantee of the Fifth Amendment has never been satisfactorily answered." ${ }^{135}$ The logical poverty of this rationale is further revealed by comparison to the similarly implied federal power to conduct foreign relations. Even though the federal foreign relations power is not grounded in the Constitution itself, but is inherent in national sovereignty, ${ }^{136}$ the Court has not refrained from exercising judicial review over the exercise of that implicit power. ${ }^{137}$ Reciting a pro forma incantation to this inherent-in-nationalsovereignty source of federal immigration power is meaningless as a rationale for judicial deference. ${ }^{138}$

\section{d. Political Question and Foreign Affairs Deference}

The enduring force of the inherent-in-national-sovereignty rationale

132. The Court first used the phrase in Nishimura Ekiu v. United States, 142 U.S. 651,659 (1892). This rationale is repeated in the modern cases. For example, in Kleindienst v. Mandel, 408 U.S. 753 (1972) (quoting the government brief with approval), the Court stated,

[T] he power to exclude aliens is "inherent in sovereignty, necessary for maintaining normal international relations and defending the country against foreign encroachments and dangers-a power to be exercised exclusively by the political branches of the government ...."

Id. at 765 (quoting Brief for Appellants at 20).

133. See S. LEGOMSKY, supra note 54, at 184-87.

"[The federal government] does not possess all the powers wlich usually belong to the sovereignty of a nation. Certain specified powers, enumerated in the Constitution, have been conferred upon it; and neither the Legislative, Executive, nor Judicial Departments of the Government can lawfully exercise any authority beyond the limits marked out by the Constitution."

Id. at 187 (quoting Scott v. Sandford, 60 U.S. (19 How.) 393, 401 (1856)); see also Fong Yue Ting v. United States, 149 U.S. 698, 737 (1893) (Brewer, J., dissenting), quoted at supra note 115; L. Henkin, Foreign Affairs ANd the Constitution 23, $289-91$ (1972).

134. 342 U.S. 580 (1952).

135. Id. at 599 (emphasis in original).

136. United States v. Curtiss-Wright Export Corp., 299 U.S. 304, 318 (1936).

137. See infra note 141 and accompanying text.

138. For a more thorough discussion of this rationale, see S. LEGOMSKY, supra note 54, at 319 21; Note, Constitutional Limits, supra note 29, at 966-74. 
probably stems from its close association with the related doctrines of deference in the conduct of foreign relations and abstention from political questions. In fact, courts have expressly relied upon these doctrines to justify the plenary power doctrine. ${ }^{139}$ While the doctrines themselves are valid, they are often erroneously cited as support for blanket deference in all immigration matters. ${ }^{140}$

In a particular case, either of these doctrines may require deference, but the case law on deference in foreign relations ${ }^{141}$ and the political question doctrine ${ }^{142}$ clearly requires that the doctrines be applied on a case-by-case basis. That individualized approach will be applied, below, to the challenges presented in this Comment, ${ }^{143}$ but neither doctrine supports a sweeping limit on the judicial review of immigration matters.

This brief survey of the proffered justifications for the plenary power doctrine demonstrates that they do not withstand critical scrutiny.

\section{The Judicial Role and Constitutional Values}

The plenary power doctrine has also been criticized on a more fundamental level: it violates the basic norms of judicial responsibility and is

139. In Mathews v. Diaz, 426 U.S. 67 (1976), the Court stated, "the reasons that preclude judicial review of political questions also dictate a narrow standard of review of decisions made by the Congress or the President in the area of immigration and naturalization." Id. at 81-82, quoted with approval in Fiallo v. Bell, 430 U.S. 787, 796 (1977). The explicit reliance on political question deference in Mathews raises the question of what is "political" (in the "political question" sense) about the decision to accord preferred immigration status to illegitimate children of immigrant mothers, but not to illegitimate children of immigrant fathers.

140. See, e.g., Kleindienst v. Mandel, 408 U.S. 753, 766 \& n.6 (1972); Galvan v. Press, 347 U.S. 522,530 (1954). The relationship of immigration law to foreign relations and political question deference has been written about extensively. See, e.g., L. HENKIN, supra note 133; S. LEGOMSKY, supra note 54, at 301-14; Henkin, Chinese Exclusion, supra note 97; Note, Constitutional Limits, supra note 29 , at $972-74$.

141. In Perez v. Brownell, 356 U.S. 44 (1958), overruled on other grounds by Afroyim v. Rusk, 387 U.S. 253 (1967), the Court said:

Broad as the power in the National Government to regulate foreign affairs must necessarily be, it is not without limitation. The restrictions confining Congress in the exercise of any of the powers expressly delegated to it in the Constitution apply with equal vigor when that body seeks to regulate our relation with other nations.

356 U.S. at 58.

The Court has frequently invalidated congressional or executive action when foreign affairs were implicated. See, e.g., Kennedy v. Mendoza-Martinez, 372 U.S. 144, 164-65 (1963) ("It is fundamental that the great powers of Congress to conduct war and to regulate the Nation's foreign relations are subject to the constitutional requirements of due process."); see also New York Times Co. v. United States, 403 U.S. 713 (1971); Aptheker v. United States, 378 U.S. 500 (1964); Schneider v. Rusk, 377 U.S. 163 (1964); Youngstown Sheet \& Tube Co. v. Sawyer, 343 U.S. 579 (1952).

142. Baker v. Carr, 369 U.S. 186 (1962), required, instead of a blanket application of the political question doctrine, that the Court engage in a "discriminating inquiry into the precise facts and posture of the particular case, and [recognize] the impossibility of resolution by any semantic cataloguing." Id. at 217 .

143. These deference doctrines must be reckoned with, however, on an individual basis before either of the two challenges set forth in this Comment can proceed. See infra notes 249-272 (resident-alien exception) \& 273-295 (PLO exception) and accompanying text. 
out of step with the proud judicial achievements protecting individual liberties in other areas.

Expressing outrage at the harsh McCarthy-era applications of the plenary power doctrine, ${ }^{144}$ Professor Henry Hart argued:

[A] power to lay down general rules, even if it were plenary, did not necessarily include a power to be arbitrary or to authorize administrative officials to be arbitrary. ... [I]n such a regime the courts had a responsibility to see that statutory authority was not transgressed, that a reasonable procedure was used in exercising the authority, and-seemingly also- that human beings were not unreasonably subjected, even by direction of Congress, to an uncontrolled official discretion. ${ }^{145}$

Hart's argument draws on the expansive concept of judicial responsibility originally articulated by Justice Marshall in Marbury v. Madison, ${ }^{146}$ a concept which, for better or worse, underlies the practice of judicial review in all areas of U.S. law.

In two articles, ${ }^{147}$ Professor Henkin criticizes the anachronism of maintaining a practice of judicial abdication that was developed contemporaneously with cases such as Dred Scott v. Sandford. ${ }^{148}$ Calling it " 'a relic from a different era," "149 Henkin argues that the plenary power

'144. Hart characterizes as "a preposterous proposition" Justice Minton's statement in United States ex rel. Knauff v. Shaughnessy, 338 U.S. 537 (1950), that " '[w] hatever procedure authorized by Congress is, it is due process as far as an alien denied entry is concerned.' " Hart, supro note 97, at 1392 (quoting Knauff, 338 U.S. at 544).

145. Hart, supra note 97 , at 1390 . Hart went on to argue that the plenary power doctrine violates

[t]he great and generating principle of this whole body of law-that the Constitution always applies when a court is sitting with jurisdiction in habeas corpus. For then the court has always to inquire, not only whether the statutes have been observed, but whether the petitioner before it has been "deprived of life, liberty, or property, without due process of law," or injured in any other way in violation of the fundamental law.

Id. at 1393.

146. 5 U.S. (1 Cranch) 137 (1803). One of the most quoted statements in the United States Reports is Justice Marshall's statement in Marbury:

It is emphatically the province and duty of the judicial department to say what the law is. ...

So if a law be in opposition to the constitution ... the court must determine which of these conflicting rules govern the case. This is of the very essence of judicial duty. . .

....

Those then who controvert the principle that the constitution is to be considered, in court, as a paramount law, are reduced to the neeessity of maintaining that eourts must close their eyes on the constitution, and see only the law.

This doctrine would subvert the very foundation of all written eonstitutions. Id. at 177-78.

147. Henkin, Chinese Exclusion, supra note 97; Henkin, Constitution as Compact, supra note 97.

148. 60 U.S. (19 How.) 393 (1857). Similarily, Steven Shapiro states: "[R]eliance on Chinese Exclusion Case is a bit like reliance on Dred Scott v. Sandford or Plessy v. Ferguson. Although the Supreme Court has never expressly overruled Chinese Exclusion Case, it represents a discredited page in the country's constitutional history. Shapiro, supra note 29, at 942 (citations omitted).

149. Henkin, Chinese Exclusion, supra note 97, at 802 (quoting Reid v. Covert, 354 U.S. 1, 12 (1957)). 
doctrine does not belong in a modern jurisprudence that has made such great strides in protecting individual rights in other areas:

That era was one in which constitutional restraints were deemed inapplicable to actions by the United States outside its territory; when orotund generalities about sovereignty and national security were a substitute for significant scrutiny of governmental action impinging on individual rights; when the Bill of Rights had not yet become our national hallmark and the principal justification and preoccupation of judicial review. ${ }^{150}$

In the immigration context, the notion that the federal government's treatment of aliens need not conform to constitutional limitations rests on an archaic and restrictive view of the scope of the Constitution's purpose. This view assumes that the Constitution protects "us," not "them," and that this protection is a personally held right, bestowed, like a prize, by the Constitution on U.S. citizens only. Contrasting with this view is the attitude expressed in the Constitution and its Preamble: that the Constitution acts as a structural and ethical guide for the U.S. government itself. It was such a notion that animated Justice Clark to state in Mapp v. Ohio ${ }^{151}$ that "[n]othing can destroy a government more quickly than its failure to observe its own laws, or worse, its disregard of the charter of its own existence."152

Nothing in the Constitution restricts its application to U.S. citizens. As Professor Henkin concludes,

The people of the United States ordained a compact which established a community of conscience and righteousness. The compact applies to everything done by the community and its officials, in the United States and elsewhere, affecting citizens and aliens alike, and concerning immigration no less than other matters. The rights our ancestors

150. Id. It is not lack of modernity per se that is problematic in the plenary power doctrine. Rather, judicial tolerance of government action violating constitutionally protected values is a reproach to the respect which the judiciary-and ultimately, society-holds for those values. As Professor Henkin writes, "[t]he Chinese Exclusion doctrine and its extensions have permitted, and perhaps encouraged, paranoia, xenophobia, and racism, particularly during periods of international tension." Id. at 859 . Looking to the ignominious history of the exercise of plenary power in immigration, Henkin concludes:

The doctrine ... emerged in the oppressive shadow of a racist, nativist mood a hundred years ago. It was reaffirmed during our fearful, cold war, McCarthy days. It has no foundation in principle. It is a constitutional fossil, a remnant of a prerights jurisprudence that we have proudly rejected in other respects.

Id. at 862 .

Professor Scanlan describes the prevailing mentality that produced the plenary power doctrine as an "essentially Hobbesian view of the world, [where] the highest obligation of the sovereign is survival, and the political branches of government, not the courts, determine what threats exist and what immigration policy is necessary to overcome those threats." Scanlan, supra note 29, at 1501-02 (footnotes omitted).

151. 367 U.S. 643 (1961) (applying the fourth amendment exclusionary rule to the states).

152. Id. at 659 . 
recognized as inherent and unalienable knew neither bounds nor state boundaries. ${ }^{153}$

In short, the judiciary should no more defer in the immigration context than in any other context when the actions of the other branches violate the norms of the constitutional compact.

\section{Summary}

This wide-ranging critique of the plenary power doctrine demonstrates that it is not a tenable doctrine, especially where government action affects individual rights. The cases cited as precedent neither support nor require judicial deference. Nor do the rationales offered to justify the doctrine support it. Finally, the doctrine essentially permits the violation of express constitutional values, while keeping the judiciary from shouldering its traditional responsibility to protect and enforce those values. Taken together, these arguments make a compelling case for abandoning the concept of plenary power over immigration matters.

\section{The Potential Demise of Plenary Power}

In the face of challenges by aliens that the federal government violated constitutionally protected rights, ${ }^{154}$ recent Supreme Court statements on the plenary power doctrine appear to constitute ringing endorsements of continued, near-absolute deference to all except "wholly irrational"15s acts of Congress. There are signs, however, that support for the plenary power doctrine is eroding and that the Court is preparing to move away from such deference. These indications are found in the analyses and rhetoric of Kleindienst v. Mandel, ${ }^{156}$ Mathews v. Diaz, ${ }^{157}$

153. Henkin, Constitution as Compact, supra note 97, at 34.

154. The Court recently evaded such a challenge in Jean v. Nelson, 472 U.S. 846 (1985). In Jean, the Court faced an equal protection challenge charging that the INS's policy of detention without parole for Haitian asylum seekers constituted national-origin discrimination. The Court (over Marshall's vigorous dissent) skirted the constitutional issue and remanded on regulatory grounds in what amounted to a limited ruling for the plaintifs.

The Court granted certiorari in another challenge, Abourezk v. Reagan, 785 F.2d 1043 (D.C. Cir. 1986), vacating 592 F. Supp. 880 (D.D.C. 1984), cert. granted, 479 U.S. 1016 (1986), aff'd by an equally divided Court, 484 U.S. 1 (1987), in which the circuit court vacated the district court's upholding of visa denials and remanded for an examination of whether such denials were within the constitutional and statutory authority of the State Department. The circuit court stated that "the Immigration Act emphatically did not commit the decision to exclude an alien to standardless agency discretion," since congressional delineation of grounds for exclusion clearly defined the Secretary of State's discretion in this area. 785 F.2d at 1051. For further discussion of the circuit court opinion, see Note, First Amendment, supra note 29, at 168-71.

Because the Supreme Court (with eight justices sitting) was equally divided in its consideration of the case, the opinion of the circuit court was affirmed solely on the basis of that division. Such an affirmation has no precedential weight. See Neil v. Biggers, 409 U.S. 188, 192 (1972).

155. Mathews v. Diaz, 426 U.S. 67, 83 (1976).

156. 408 U.S. 753 (1972).

157. 426 U.S. 67 (1976), discussed at supra notes 217-228 and accompanying text. 
and Fiallo v. Bell, ${ }^{158}$ and in the Court's decision in INS v. Chadha. ${ }^{159}$ Pressure from the lower courts has also chipped away at the doctrine's foundations. ${ }^{160}$ This section discusses how these recent cases signal the demise of the plenary power doctrine.

\section{Promising Analysis and Rhetoric}

Although the holdings of Kleindienst v. Mandel ${ }^{161}$ and Fiallo v. $B e l{ }^{162}$ appear to reaffirm the plenary power doctrine at its most extreme, the language and analysis in both cases convey a more complicated and, surprisingly, ambivalent attitude. In Mandel the Court went so far as to uphold a visa denial even in spite of acknowledged damage to the first amendment rights of U.S. citizens. ${ }^{163}$ Yet the Court did not simply defer to an absolute congressional power. It expressly declined to adopt the government's position that Congress can authorize the executive to admit aliens "in its sole and unfettered discretion, [and] any reason or no reason may be given." 164 Rather, the Court limited its holding by noting that the government did give a "facially legitimate and bona fide" reason-prior visa abuse ${ }^{165}$-for denying Mandel's visa application. Since

158. 430 U.S. 787 (1977).

159. 462 U.S. 919 (1983).

160. Other commentators have documented the creativity with which the lower courts have evaded the plenary power doctrine's constraints. See Martin, supra note 86, at 169-71; Schuck, supra note 97, at 58-72; Note, First Amendment, supra note 29, at 164-71.

The holdings in Rafeedie v. INS, 688 F. Supp. 729 (D.D.C. 1988) (preliminary injunction granted against summary exclusion proceeding in order to determine constitutionality of procedure in that case), and ADC. v. Meese, 714 F. Supp. 1060 (C.D. Cal. 1989) (ideological exclusion provisions of INA unconstitutionally restrict first amendment rights of resident aliens), are examples of this lower court restiveness. Not all lower courts, however, have tried to evade the constraints of the plenary power doctrinc. See, e.g., Nongovernmental Organization, Comm. on Disarmament v. Haig, No. 82 Civ. 6147 (S.D.N.Y. Jun 10, 1982) (LEXIS, Genfed library, Dist file) (deferring to any government rationale not "patently absurd"), aff'd mem., 697 F.2d 294 (2d Cir. 1982).

161. 408 U.S. 753 (1972), discussed at supra notes $89-90$ and at infra notes 222-227 \& 236-238 and accompanying text.

162. 487 U.S. 787 (1977), discussed at supra notes $91-96$ and accompanying text. As Professor Legomsky states,

Of all the immigration cases the Supreme Court had decided, Fiallo appears to be the one in which the arguments for broad judicial review were the strongest. The statutory provision in question classified not only by alienage, but also by gender and legitimacy. The latter two classifications are normally subjected to some form of heightened judicial scrutiny. Further, the interests of the plaintiffs, some of whom were American citizens, included family reunification, a factor that might be expected to favour broader review. Arguably, any one of those factors should have elevated the standard of review. The combination should certainly have had that effect.

S. LEGOMSKY, supra note 54, at 206 (citations omitted).

163. The Court acknowledged that the first amendment interests of U.S. citizens were injured, yet refused to weigh that injury against the State Department's proferred content-neutral basis for the denial, even though this basis was arguably secondary to the ideological suppression. Mandel, 408 U.S. at 763-70.

164. Id. at 769 .

165. The State Department stated that Mandel had "engaged in activities beyond the stated 
this reason was unrelated to free expression, the Court upheld the government's position. In so doing, the Court expressly declined to decide "[w]hat First Amendment or other grounds may be available for attacking exercise of discretion for which no justification whatsoever is advanced ...."166

Thus, the Mandel Court pointedly refused to hold that the plenary power doctrine prohibits the Court from invalidating ideological exclusion. Rather, the Court gave the State Department the benefit of the doubt and treated Mandel's exclusion as if it were not ideological exclusion at all, but merely a consequence of prior visa abuse. The Court's facially-legitimate-and-bona-fide standard of review was minimal, though ambiguous. ${ }^{167}$ Furthermore, the Court broadly implied that it would, in fact, intervene if faced with a visa denial based solely on ideology. ${ }^{168}$

Similarly, although the Court in Fiallo v. Bell ${ }^{169}$ upheld a statutory distinction that would be clearly unconstitutional for U.S. citizens, ${ }^{170}$ the opinion indicates the Court's reluctance to surrender all judicial responsibility in the area of immigration. In footnote 5, Justice Powell states, "Our cases reflect acceptance of a limited judicial responsibility under the Constitution even with respect to the power of Congress to regulate the admission and exclusion of aliens ...."171 To ensure that the point

purposes" of an earlier trip. Id. at 758; see also id. n.5. For a contrary view of Mandel's alleged prior visa abuse, see Douglas' dissent, id. at 773 n.4.

166. Id. at 770 .

167. Not surprisingly, the lower courts are widely divergent in their analyses. Most treat "facially legitimate and bona fide" as a very minimum level of review. See, e.g. Sidney v. Howerton, 777 F.2d 1490, 1491 (11th Cir. 1985) ("facially legitimate" is "extremely deferential" standard of reivew); Garcia-Mir v. Smith, 766 F.2d 1478, 1485 (11th Cir. 1985) ("facially legitimate" is less stringent standard than abuse of discretion); Bertrand v. Sava, 684 F.2d 204, 212 n.12 (2d Cir. 1982) (equating "facially legitimate" with "wholly irrational").

Some lower courts, however, treat the Mandel standard as requiring a eonsiderably higher level of review. See, e.g., Allende v. Shultz, 605 F. Supp. 1220, 1224 (D. Mass. 1985) (government must justify exclusion "not only in a general sense, but also within the context of the specific statutory provision on which the exclusion is based."); Harvard Law School Forum v. Shultz, 633 F. Supp. 525 (D. Mass. 1986) (following the standard articulated in Allende), vacated without opinion, 852 F.2d 563 (1st Cir. 1986).

The scholarly commentary also varies. Gordon and Rosenfield suggest, "[t]he apparent thrust of the Court's suggestion is that the 'limited judicial review' might be invoked . . . to challenge the most blatant type of discrimination, e.g., exclusions based solely on religion or race." C. GORDON \& S. Mailman, Immigration LAw AND Procedure vol. 1 \$9.01, at 9-5 (1989)(quoting Fiallo v. Bell, 430 U.S. 787, 795 n.6). By contrast, Schuck, supra note 97, at $65-66$, suggests that this formulation signals the dawning of a new judicial assertiveness.

168. Mandel, 408 U.S. at 770 ("What First Amendment or other grounds may be available for attacking exercise of discretion for which no justification whatsoever is advanced is a question we neither address nor decide in this case.") For further discussion of Mandel arguing that it provides support for a first amendment exception to plenary power, see infra notes 221-243 and accompanying text.

169. 430 U.S. 787 (1977).

170. See supra notes 91-96 and accompanying text.

171. Fiallo, 430 U.S. at 793 n.5. 
was not lost, the next footnote repeats it: "This is not to say, as we make clear in n.5, supra, that the Government's power in this area is never subject to judicial review."172 These footnotes hardly proclaim a commitment to full judicial review of immigration issues, ${ }^{173}$ but they signal a restiveness that is markedly inconsistent with the traditional attitude of plenary power deference.

\section{INS v. Chadha}

In light of their holdings, the statements made in Mandel and Fiallo indicate only the most modest beginnings of a new judicial temerity. Read in the context of INS v. Chadha, ${ }^{174}$ however, these tentative statements may prove to mark the first steps toward a definitive rejection of plenary power deference.

In Chadha the Court for the first time invalidated immigration legislation as unconstitutional. Chadha deals with a section of the INA that allows the Attorney General to suspend the deportation of an otherwise deportable alien, ${ }^{175}$ but gives either house of Congress a "legislative veto" over such a suspension. ${ }^{176}$ The Court struck down this section as a violation of the separation of powers, reasoning that since a legislative veto is, in fact, "legislative," the Constitution in sections 1 and 7 of article $I^{177}$ requires a vote by both houses of Congress and submission to the President for assent or veto. ${ }^{178}$

The Chadha decision reflects separation-of-powers concerns that are only tangential to immigration law, and therefore the case has wide-ranging consequences outside the immigration context. ${ }^{179}$ Yet one of the explicit defenses of the legislation was grounded in the plenary power doctrine. ${ }^{180}$ The Court summarily dismissed this defense, however, stating, "The plenary authority of Congress over aliens under [the naturalization clause ${ }^{181}$ ] is not open to question, but what is challenged here is

172. Id. at 795 n.6.

173. To avoid overstating the point, it must be kept in mind that the Fiallo opinion also contains language strongly reaffirming plenary power deference. For example, it states, "[t]his Court has repeatedly emphasized that "over no conceivable subject is the legislative power of Congress more complete than it is over' the admission of aliens." Id. at 792 (quoting Oceanic Navigation Co. v. Stranahan, 214 U.S. 320, 339 (1909).

174. 462 U.S. 919 (1983).

175. INA § 244(a), 8 U.S.C. § 1254(a) (1982).

176. INA $\S 244(c)(2), 8$ U.S.C. $\$ 1254(c)(2)(1982)$.

177. U.S. CoNST. art. I, $\S \S 1,7$ (bicameralism), art. I, $\S 7 \mathrm{cl} .3$ (presentation to president for approval or veto).

178. 462 U.S. at $946-59$.

179. Nearly 300 similar provisions for legislative vetoes in other areas are also threatened by the Chadha holding. See S. LEgOMSKY, supra note 54 at 214-15.

180. One of the House briefs devoted twelve pages to the issue, citing almost every major plenary power decision. Id. at 215.

181. The Chadha Court determined that the Naturalization Clause (U.S. ConsT. art. I, § 8, cl. 
whether Congress has chosen a constitutionally permissible means of implementing that power." 182

This blithe dismissal of the plenary power doctrine hardly represents a principled or express abandonment of deference to the plenary power of the other branches. Nevertheless, Chadha represents a direct threat to the continued hegemony of the plenary power doctrine. Although it does not involve a violation of constitutionally protected rights, ${ }^{183}$ Chadha expressly rejects the view that the plenary power doctrine authorizes carte blanche exercise of congressional power over immigration. In an area of law dominated by precedent, Chadha appears portentious indeed.

\section{Conclusion}

In immigration law, where incantations to venerable authority have locked the Court into an approach that is inconsistent with modern jurisprudence and with which it is manifestly uncomfortable, Chadha may have cut the Gordian knot. Now, the plenary power doctrine is bracketed by anomalies: The most venerable and authoritative precedent for plenary power-The Chinese Exclusion Case-does not stand for plenary power at all, ${ }^{184}$ and the most recent case-Chadha-ignores it. ${ }^{185}$ Between these two temporal extremes lies an ignominious history, which the Court should repudiate.

4) is the source of the immigration power without relying on the customary doctrine that the power is not grounded in the Constitution, but rather "inherent in sovereignty," see Kleindienst v. Mandel, 408 U.S. 753, 765 (1972). If the immigration power is no longer seen as extraconstitutionally derived, this strengthens the argument that the immigration power should be subject to the limits of the entire Constitution-including its protection of individual rights.

182. Chadha, 462 U.S. at 940-41. Professor Legomsky notes, "Given the Court's actions, it is not clear what, if anything, the word 'plenary' actually adds." S. LEGOMSKY, IMM1GRATION, supra note 54, at 216 (footnote omitted). The point of his remark is that after Chadha "plenary" is an essentially meaningless constraint on judicial review. But his question can be answered seriously by returning to the original plenary power decision-The Chinese Exclusion Case-where the evident meaning of the phrase was that federal immigration power was plenary vis-a-vis the states and other countries but not vis-a-vis the judiciary. See supra notes 110-118 and accompanying text.

Another answer, closer to the spirit of Professor Legomsky's question, is offered by the Cliadla Court itself. "Plenary" means that the power is plenary "so long as the exercise of that authority does not offend some other constitutional restriction." "Chadha, 462 U.S. at 941 (quoting Buckley v. Valeo, 424 U.S. 1, 132 (1976)). This accords with Professor Tribe's description of the "plenary" power of Congress over commerce: "[1]t is now settled that Congress may impose whatever conditions it wishes, so long as the conditions themselves violate no independent constitutional prohibition ...." L. TR1BE, AmER1CAN CONSTITUTIONAL LAW $\S 5-6$, at 311-12 (1978).

183. Professor Schuck warns against undue reliance upon Chadha as portending the end of plenary power because the Court was preoccupied with the issue of legislative veto and separation of powers. Schuck, supra note 13 , at 59 n.319.

184. See supra notes $110-116$ and accompanying text.

185. See supra notes $174-183$ and accompanying text. 


\section{A First Amendment Exception to the Plenary Power Doctrine}

The plenary power doctrine need not be categorically rejected in order to justify judicial review of the constitutionality of section 901 . Demonstrating a first amendment exception to the plenary power doctrine allows the constitutional challenges made in this Comment to proceed. Such an exception is, in fact, the basis of the district court's holding in American-Arab Anti-Discrimination Comm. (ADC) v. Meese, ${ }^{186}$ that the ideological exclusion provisions of the McCarranWalter Act are unconstitutional on their face with respect to aliens in the United States. ${ }^{187}$

The existence of a first amendment exception to the plenary power doctrine might seem surprising, given the Court's holding in Mandel, ${ }^{188}$ but the decision in that case is expressly limited to resident aliens and expressly avoids facing the first amendment issue. This Comment argues that the case law supports a first amendment exception for all aliens, but certainly (as $A D C$ v. Meese held ${ }^{189}$ ) at least for aliens in the United States. This first amendment exception is supported by a careful reading of several Supreme Court cases. Harisiades v. Shaughnessy ${ }^{190}$ is the inost important, but Bridges v. Wixen, ${ }^{191}$ Rowoldt v. Perfetto, ${ }^{192}$ Mathews v. Diaz, ${ }^{193}$ and even Mandel contribute support for the exception applied in Harisiades and $A D C$ v. Meese.

\section{The Case Law Supporting a First Amendment Exception}

Harisiades $v$. Shaughnessy ${ }^{194}$ is the only Supreme Court case since

186. 714 F. Supp. 1060 (C.D. Cal. 1989).

187. The $A D C$ court discussed the relevance of the first amendment to deportation of aliens, distinguishing the cases relied upon by the government as requiring plenary power deference on the basis that the cases cited either did not relate to resident aliens, or involved exclusion, not deportation. Id. at 1075-82. The $A D C$ opinion maintained that aliens within the United States are entitled to first amendment rights and noted that only one Supreme Court case, Harisiades $v$. Shaughnessy, 342 U.S. 580 (1952), had directly faced a first amendment challenge to the deportation of a resident alien. $A D C, 714 \mathrm{~F}$. Supp. at 1077. The $A D C$ court noted that in Harisiades, the Supreme Court applied the then-prevailing domestic first amendment standard. The $A D C$ court reasoned, therefore, that it should apply the current domestic first amendment standard articulated in Brandenburg v. Ohio, 395 U.S. 444 (1969). The court concluded that, under the Brandenburg standard, the ideological grounds of exclusion were facially unconstitutional because they are substantially overbroad in that they encompass expression that does not create an imminent threat of violence. $A D C, 714 \mathrm{~F}$. Supp. at 1082-84. The court's analysis is substantially identical to that discussed at infra notes 196-228 and accompanying text, except that this Comment does not restrict its argument to aliens within the United States.

188. 408 U.S. 753 (1972), discussed at supra notes $89-90$ and accompanying text.

189. See infra note 197 .

190. 342 U.S. 580 (1952).

191. 326 U.S. 135 (1945).

192. 355 U.S. 115 (1957).

193. 426 U.S. 67 (1976).

194. 342 U.S. 580 (1952). 
United States ex rel. Turner v. Williams ${ }^{195}$ to rule directly on a first amendment challenge to the deportation of resident aliens. ${ }^{196}$ It was upon Harisiades that Judge Wilson relied in $A D C v$. Meese, holding ideological exclusion facially unconstitutional as violating freedom of expression. ${ }^{197}$ Harisiades and the other cases that support a first amendment exception to the plenary power doctrine (except Mandel) all involve resident aliens, suggesting that the exception is limited to either permanent resident aliens or aliens already in the United States. As this Comment argues below, however, the Court's treatment of the aliens' residential status in these cases does not require that the first amendment exception be limited to aliens in the United States. Only the facts, not the logic, of these cases support such a limitation. The logic of those cases suggests that the first amendment exception should apply as well in cases where aliens are applying to enter the United States. ${ }^{198}$

Harisiades involved the deportation of three long-term resident aliens (of 32, 36, and 38 years) for membership in the Communist Party. The aliens had resigned from the Communist Party before Party membership was made a deportable offense. The Court upheld the deportations against challenges based on substantive due process, the ex post

195. 194 U.S. 279 (1904).

196. In $A D C$ v. Meese, District Judge Wilson distinguished Turner from Harisiades by finding that the Court in Turner exercised complete deference to the exclusion of a nonresident alien. ADC v. Meese, 714 F. Supp. at 1076. Judge Wilson found that, by contrast, the Harisiades Court had exercised judicial review of the deportation of a resident alien. Id. at 1077. Thus, he was able to conclude that the Supreme Court had never exercised plenary power discretion towards a first amendment challenge by a resident alien. Id. at 1078. Judge Wilson's distinction rests on the repeated use by the Turner Court of the word "exclusion" (connoting denial of entry). See supra note 13.

In fact, it is impossible to tell from the lower court opinion, 126 F. 253 (N.Y. Cir. 1903), or the Supreme Court opinion, 194 U.S. 279 (1904), whether Turner was a resident alien or not. Clearly, he was in the United States when he exercised the expression for which he was "excluded." Turner, 194 U.S. at 281-82. The better view is that Turner was excluded before the resident versus nonresident distinction was relevant to immigration law, and, furthermore, that such a distinction was surely irrelevant to ideological exclusion in 1952, since he would have been excluded even if hc had been a resident alien. In 1904, even U.S. citizens did not have the first amendment protections that would have protected Turner's expression. See Abrams v. United States, 250 U.S. 616 (1919). Thus, Harisiades was decided at a time when first amendment protections were beginning to be developed generally. The earlier Turner decision was simply archaic, both in terms of immigration law and first amendment law. Turner, thus, does not need to be distinguished from Harisiades on the basis of immigration status of the aliens involved.

197. American-Arab Anti-Discrimination Comm. v. Meese, 714 F. Supp. 1060, 1083 (C.D. Cal. 1989) ("Like the Supreme Court in Harisiades, we review the deportation statute employing the prevailing First Amendment standard.") The court determined that "[I]t takes no searching inquiry to conclude that, judged according to the prevailing Brandenburg test, the challenged provisions cannot pass constitutional muster." Id. at 1084.

Judge Wilson's opinion in $A D C$ v. Meese discusses and applies to all aliens in the United States, not just resident aliens. $I d$. at $1063,1084 \mathrm{n} .19$. Several of the plaintiffs in that case were nonimmigrant aliens and two were resident aliens. The opinion applies equally to all of them.

198. See infra notes 231-243 and accompanying text. 
facto clause, and the first amendment. With respect to the due process and ex post facto challenges, the Court clearly deferred to the plenary powers of the other branches. ${ }^{199}$

Rather than defer on the first amendment challenge, however, the Court applied the standard first amendment analysis to the deportation. The government contended that the first amendment does not constrain " 'the political decision of Congress to expel a class of aliens whom it deem[s] undesirable residents." "200 The Court rejected this argument, stating: "We apprehend that the Constitution enjoins upon us the duty, however difficult, of distinguishing between [constitutionally protected and unprotected speech]."201

Dennis v. United States ${ }^{202}$ defined the first amendment standard applicable at the time of Harisiades. ${ }^{203}$ According to Harisiades, this standard permitted the government to suppress expression that amounts to "methodological but prndent incitement to violence."204 However, the Court concluded that the test was met in this case, so "the First Amendment [did] not prevent the deportation of these aliens." 205

Unfortunately, the language of Harisiades does not explicitly repudiate plenary power deference in cases where the first amendment is implicated. It does not state that it is abandoning such deference, nor does it mention the fact that its analysis appears to overrule United States ex rel. Turner v. Williams. ${ }^{206}$ Indeed, the Court's application of the Dennis standard is somewhat cryptic. ${ }^{207}$ Yet given the extraordinary hold of

199. For example, in that section of the opinion dealing with the due process challenge, the Court stated, "Such matters [as immigration] are so exclusively entrusted to the political branches of government as to be largely immune from judicial inquiry or interference." Harisiades, 342 U.S. at 589 (footnote omitted).

200. Brief for United States, Harisiades v. Shaughnessy, reprinted in 96 L. Ed. 580, 593 (1951)(quoted in ADC v. Meese, 714 F. Supp. at 1077).

201. Harisiades, 342 U.S. at 592.

202. 341 U.S. 494 (1951).

203. Dennis relaxed the "clear and present danger" test so that advocacy of violent overthrow of the government, without the probability that such action would be successful, met the test. Id. at 509.

204. 342 U.S. at 592. More fully, the Harisiades Court stated:

To arm all men for orderly change, the Constitution put in their hands a right to influence the electorate by press, speech and assembly. This means freedom to advocate or promote Communism by means of the ballot box, but it does not include the practice or incitement of violence.

True, it often is difficult to determine whether ambiguous speech is advocacy of political methods or subtly shades into a methodical but prudent incitement to violence .... We apprehend that the Constitution enjoins upon us the duty, however difficult, of distinguishing between the two.

342 U.S. at 592 (citing Dennis v. United States, 341 U.S. 494 (1951)).

205. Id.

206. 194 U.S. 279 (1904), discussed at supra notes 31, 88 \& 195-196 and accompanying text.

207. In ADC v. Meese, 714 F. Supp. 1060 (C.D. Cal. 1989), the government argued that Harisiades incorrectly and ambiguously applied the Dennis standard and therefore Harisiades cannot be held to establish a first amendment exception to the plenary power doctrine. The $A D C$ opinion 
precedent in the field of immigration law (and the mood of the country in 1952), it is not surprising that the Court applied the prevailing first amendment standard without boldly announcing a first amendment exception to the plenary power doctrine.

Nevertheless, the standard applied in Harisiades speaks for itself and distinctly recognizes a first amendment exception to the plenary power doctrine. The fact that the Court applied differing standards of review to the due process claim and the first amendment claim demonstrates this recognition. No Supreme Court decision has since repeated this analysis or confirmed the import of its holding, ${ }^{208}$ but neither has any opinion repudiated it.

Furthermore, Harisiades is not as isolated as it might seem; in two other immigration cases implicating the first amendment the Court also declined to defer its review. Seven years before Harisiades, in Bridges $v$. Wixon, ${ }^{209}$ the Court invalidated the highly publicized deportation of Harry Bridges for affiliation with the Communist Party. The Court overturned the deportation by narrowly interpreting the statutory term "affiliation," defining it to mean active involvement with the Party in furthering its goal of violent overthrow of the government. Additionally, in his majority opinion, Justice Douglas stated that "[f]reedom of speech and of press is accorded aliens residing in this country."210 Justice Murphy's concurring opinion is even more explicit: "Since resident aliens have constitutional rights, it follows that Congress may not ignore them in the exercise of its 'plenary' power of deportation."211

Although based on statutory interpretation, Bridges has constitutional force because the Court used "correctives" interpretation to avoid constitutional problems with the plain language of the statute. Justice Douglas stated, "we cannot believe that Congress intended to cast so wide a net as to reach those whose ideas and program, though coinciding with the legitimate aims of such groups, nevertheless fell far short of overthrowing the government by force and violence."212 Thus, as the Court said in a closely analogous context: "although the holding was

disagreed but concluded that the adequacy of the Harisiades application of Dennis was irrelevant. Rather, the court held, the point was that the Harisiades Court explicitly chose to apply the prevailing domestic first amendment standard to this alien's claim rather than invoke the plenary power doctrine. $714 \mathrm{~F}$. Supp. at 1077 n. 12.

208. T. AlEINIKOF \& D. MARTIN, supra note 13, at 365 .

209. 326 U.S. 135 (1945).

210. Id. at 148. Douglas also quoted approvingly from a report on Bridges' activities (prepared by Dean Landis of the Harvard Law School) which stated: "That Bridges' aims are energetieally radical may be admitted, but the proof fails to establish that the methods he seeks to employ to realize them are other than those that the framework of democratic and constitutional government permits." Id. at 149 .

211. 326 U.S. at 161 (Murphy, J., concurring).

212. Id. at $147-48$. 
one of [statutory] interpretation, the rationale was one of constitutional law."213

Faced with a provision making membership in the Communist Party a ground for deportation, the Court in Rowoldt v. Perfetto ${ }^{214}$ again engaged in creative statutory interpretation. The Court held that "membership" requires "meaningful association," meaning that the individual must intend to belong to an organization which she knows is committed to the violent overthrow of the government. ${ }^{215}$

The court-created definitions in both Bridges and Rowoldt were obviously influenced by the then-prevailing first amendment standard enunciated in Dennis. The two definitions sound remarkably similar to Dennis itself, which permitted governmental suppression of expression advocating the overthrow of the government "by language reasonably and ordinarily calculated to incite persons to such action."216 Although the Court in Bridges and Rowoldt did not strike down the statutes at issue in those cases, its aggressive statutory interpretations can hardly be considered deferential. In effect, the Court applied, sub silentio, a first amendment exception to plenary power deference.

Close scrutiny of the analysis in Mathews v. Diaz ${ }^{217}$ and Kleindienst v. Mandel $^{218}$ provides more recent support for a first amendment exception to plenary power. Before applying the unless-wholly-irrational standard to a welfare classification discriminating against resident aliens, the Mathews Court pointed out that the case "involve[d] no impairment of the freedom of association of either citizens or aliens."219 The obvious implication is that a higher level of scrutiny would have been applied if the welfare classification had impaired first amendment rights. By itself, this negative inference weighs little. However, it does corroborate the existence of the first amendment exception to plenary power deference applied in Harisiades, Bridges, and Rowoldt.

Furthermore, it is significant that Mathews mentions the first amendment interests of citizens as well as aliens. As discussed below, ${ }^{220}$

213. Landon v. Plasencia, 459 U.S. 21, 33 (1982) (describing the holding of Kwong Hai Chew v. Colding, 344 U.S. 590 (1953)). Landon held that a returning alien was entitled, as a constitutional matter, to due process protections in exclusion proceedings. It relied on Kwong Hai Chew, which similarly required due process protections, but was based on interpretation of administrative regulations.

214. 355 U.S. 115 (1957).

215. Id. at 120 .

216. Dennis v. United States, 341 U.S. 494, 512 (1951).

217. 426 U.S. 67 (1976) (rejecting equal protection challenge to denial of Medicare eligibility to aliens not admitted for permanent residence and not to residents for at least five years because the classification was not "wholly irrational.").

218. 408 U.S. 753 (1972), discussed at supra notes 89-90 and accompanying text.

219. 426 U.S. at 87 .

220. Infra notes 223-228. 
the implication of the first amendment interests of citizens is a vital component of the relationship between the first amendment and judicial responsibility toward the immigration-related acts of the other branches. The Mandel opinion confirms that the Supreme Court is fully aware of this by explicitly developing the citizens' interests alluded to in Mathews.

At the outset, Mandel purports to evade the issue of the first amendment's impact on the plenary power doctrine. ${ }^{221}$ The rest of the opinion does not bear this out, however, since the Mandel majority clearly did more than simply evade the issue. Instead, what it did was lay out the logical structure for the first amendment exception to plenary power. The opinion goes to some lengths to acknowledge the first amendment interest of U.S. citizens in receiving ideas from aliens, unfettered by ideological exclusion. Quoting from Red Lion Broadcasting Co. v. FCC, the Court stated:

"It is the purpose of the First Amendment to preserve an uninhibited marketplace of ideas in which truth will ultimately prevail.... It is the right of the public to receive suitable access to social, political, esthetic, moral, and other ideas and experiences which is crucial here. That right may not constitutionally be abridged either by Congress or by the FCC."223

The Court went on to affirm that this right to receive ideas is clearly implicated in the immigration context. First, the Court cited Lamont v. Postmaster General ${ }^{224}$ for the proposition that the right of U.S. citizens to receive ideas extends to ideas coming from abroad. ${ }^{25} \mathrm{Next}$, the Mandel Court pointed out that exclusion of aliens is not precluded from first amendment review merely because it involves action rather than speech. ${ }^{226}$ Finally, the Court refused to accept the argument that the interest of citizens in receiving ideas from abroad can be adequately protected through exposure to books or other media. Rather, the Court asserted that "particular qualities inherent in sustained, face-to-face

221. The Government would have us reach this question, urging a broad decision that Congress has delegated the [power to waive an immigration restriction] to the Executive in its sole and unfettered discretion, and any reason or no reason may be given. This record, however, does not require that we do so, for the Attorney General did inform Mandel's counsel of the reason for refusing him a waiver. And that reason [prior visa abuse unrelated to expression] was facially legitimate and bona fide.

Mandel, 408 U.S. at 769 (citations omitted).

222. 395 U.S. 367 (1969).

223. 408 U.S. at 763 (quoting Red Lion Broadcasting Co., 395 U.S. at 390).

224. 381 U.S. 301 (1965) (holding that a statute permitting the government to withhold "communist political propaganda" arriving in the mails from abroad unless the addressec affirmatively requested in writing that it be delivered to him placed an unjustifiable burden on the addressee's first amendment rights).

225. Mandel, 408 U.S. at 763.

226. The Court stated, "[We] cannot realistically say that the problem facing us disappears entirely or is nonexistent because the mode of regulation bears directly on physical movement." Id. at 764 . 
debate, discussion and questioning"227 are essential to the first amendment interests of citizens.

In sum, Mandel provides a persuasive justification for a first amendment exception to the plenary power doctrine. This justification is independent of the Bridges approach, which is based on the first amendment rights of resident aliens. ${ }^{228}$ The Mandel Court was not willing, however, to go as far as holding that the first amendment rights of U.S. citizens were violated in that case. Instead, it upheld the visa denial on the basis of non-speech related prior visa abuse. Thus, on the one hand, the Mandel holding indicates a reluctance to abandon fully traditional deference to the executive in immigration matters. Yet, on the other hand, the Mandel analysis suggests that the Court is nearly ready to free itself from the constraints of the plenary power doctrine, at least in the first amendment context.

If the Court were truly committed to the plenary power doctrine, then it would not have embarked on a discussion of the first amendment rights of citizens. Even though the court backed away from announcing the exception, its extensive discussion of the first amendment rights of citizens stands as a well-articulated justification for an exception to the plenary power doctrine. Mandel's focus on the interests of U.S. citizens complements Bridges' focus on the interests of resident aliens. Together, they provide an analytical justification for decisions such as Harisiades, in which the Court applied, with minimal analysis, a first amendment exception to the plenary power doctrine.

\section{The First Amendment Exception is Not Limited to Resident Aliens}

Harisiades, Bridges, Rowoldt, and Mathews all dealt with resident aliens, and taken together, they appear to suggest that the first amendment exception to the plenary power doctrine is limited either to resident aliens or, as $A D C$ v. Meese concluded, to all aliens within the borders of the United States, whether residents or temporary visitors. However, a close analysis of Harisiades and Mandel reveals that the location and residency of the aliens are irrelevant ingredients of the first amendment exception.

Unlike Bridges, the first amendment analysis in Harisiades is not based on the notion that resident aliens have acquired constitutional protections by virtue of their residence in the United States. In fact, although the holding in Harisiades can be limited on its facts to resident aliens, the analysis employed contradicts that limitation. Before addressing any of the underlying claims, the Harisiades opinion explicitly

227. Id. at 765 .

228. Bridges v. Wixon, 326 U.S. 135 (1945), discussed at supra notes 209-213 and accompanying text. 
refused to clothe the resident aliens with any of the protections of the Constitution. ${ }^{229}$ As discussed above, however, the Court proceeded to apply the prevailing first amendment standard to the alien's deportation for membership in the Communist Party. Although this appears to contradict the Court's statement that the resident aliens have no constitutional rights, it makes perfect sense if the first amendment is seen as constraining government action itself, regardless of the speaker, or, alternatively, as protecting the rights of U.S. citizens to hear the aliens. In either case, the Court's analysis suggests that the first amendment applies in the immigration context regardless of the residence or location of the aliens imvolved. ${ }^{230}$

The discussion of the first amendment interests of U.S. citizens in Mandel supports a first amendment exception to plenary power deference where any alien is involved, not just resident aliens. Mandel was not a resident nor even in the United States, yet the Court extensively discussed the first amendment interests of U.S. citizens. ${ }^{231}$ Thus, Mandel also supports the position that the purpose of the first amendment is to constrain government action, not only to confer personally held "rights" on certain individuals.

Whether the first amendment constrains government or confers rights may seem to be a distinction without a difference. Yet in the context of immigration, it makes a vital difference. If the first amendment is viewed as a limit on government action, the identity of the beneficiary is less important than the reason for the restraint.

As a limit on government action rather than protection of individual

229. For over thirty years each of these aliens has enjoyed such advantages as accrue from residence here without renouncing his foreign allegiance or formally acknowledging adherence to the Constitution he now invokes. ...

The alien retains immunities from burdens which the citizen must shoulder. By withholding his allegiance from the United States, he leaves outstanding a foreign call on his loyalties which international law not only permits our Government to recognize but commands it to respect.

... [T]o protract this ambiguous [resident alien] status within the country is not his right but is a matter of permission and tolerance.

Harisiades v. Shaughnessy, 342 U.S. 580, 585-87 (1952).

230. This conforms to Justice Marshall's dissent in Mandel where he states, "The First Amendment means that Government has no power to thwart the process of free discussion, to 'abridge' the freedoms necessary to make that process work." Kleindienst v. Mandel, 408 U.S. 753, 776 (1972) (Marshall, J., dissenting). Justice Douglas' dissenting opinion in Mandel also focuses on the control of government itself when he states, "Thought control is not within the competence of any branch of government." Id. at 772 (Douglas, J., dissenting).

231. "It is clear that Mandel personally, as an unadmitted and nonresident alien, had no constitutional right of entry to this country as a nonimmigrant or otlierwise." Id. at 762 . However, whether Mandel had a personal right to travel to the United States does not address the broader question of whether the Constitution permits the determination of whether he would be allowed to travel to the United States to be based on the content of his beliefs or expression. The two questions are different: The latter does not necessarily involve his status as a resident or as a nonresident. 
rights, the first amendment may be seen as either a normative constraint-requiring the government to refrain from acts towards individuals which violate their dignity or degrade the community which their government represents ${ }^{232}$-or instrumental policy - seeking to ensure the maximum utility of the "free trade in ideas" 233 deemed essential to the functioning of a democracy. As the Court stated in Bose Corp. v. Consumers Union of the United States, Inc. ${ }^{234}$ "[T] The freedom to speak one's mind is not only an aspect of individual liberty-and thus a good unto itself-but also is essential to the common quest for truth and the vitality of society as a whole." 235

The Mandel Court clearly had the latter in mind when it quoted the statement in Red Lion Broadcasting that the purpose of the first amendment is "to preserve an uninhibited marketplace of ideas in which truth will ultimately prevail." ${ }^{236}$ Whether or not this utilitarian understanding of the first amendment is philosophically accurate or complete, it gives commumitarian substance to this "right" that is so often conceived as a jealously guarded personal prize of citizenship. ${ }^{237}$

It is impossible to neatly separate the communitarian from the individualistic or the utilitarian from the normative foundations of first amendment jurisprudence and it is probably not wise to do so. But in the context of immigration, the Court is particularly resistant to recognizing normative liberty interests of aliens. The concept of communitarian utility, however, provides a justification for applying first amendment constraints to immigration decisions that is well within the Court's manner of thinking. As the Court pointed out in Mandel, the interest of U.S. citizens in free communication is necessarily infringed by any action that excludes aliens, whether residents or not. ${ }^{238}$ This is particularly so where

232. See Henkin, Constitution as Compact, supra note 97, at 34 , quoted at supra text accompanying note 153. Professor Henkin continues his discussion of traditionally "inherent and unalienable" rights by concluding that the government "should respect these rights with no invidious inequalities, no arbitrary limitations on liberty, and no unnecessary interferences with those who risk all in the pursuit of some happiness." Id.

233. Abrams v. United States, 250 U.S. 616, 630 (1919) (Holmes, J., dissenting). Discussion of the political philosophy underpinning the first amendment is beyond the scope of this Comment. For an introduction to the voluminous literature on this subject, see G. GuNTHER, CASES AND MATERIAls on CONSTITUTIONAL LAW 976-79 (11th ed. 1985); L. TRIBE, supra note 182 , $12-1$, at 785-89.

234. 466 U.S. 485 (1984).

235. Id. at 503-04.

236. Mandel, 408 U.S. at 763 (quoting Red Lion Broadcasting Co. v. FCC, 395 U.S. 367, 390 (1969)).

237. For additional references to the listener's right to receive ideas, see Lamont v. Postmaster General, 381 U.S. 301, 308 (1965) (Brennan, J., concurring) ("It would be a barren marketplace of ideas that had only sellers and no buyers."); Procunier v. Martinez, 416 U.S. 396, 408-09 (1974) (discussing state prison inmates' rights to receive uncensored mail).

238. The Mandel opinion acknowledged the interrelation of first amendment interests between aliens and citizens when it stated, "In almost every instance of an alien excludable under 
the alien is excluded for ideological reasons, for that directly diminishes full participation in the "free marketplace of ideas."

Thus, despite its professed intent to avoid the issue, Mandel supports extending to immigration matters the first amendment analysis that is applied in domestic contexts-an analysis which is both instrumental and communitarian. The Court's treatment of corporate speech is illustrative of this approach. In overturning restrictions on the speech of corporations, the Court has insisted that the first amendment requires maintaining unrestricted input into the public debate on important issues. As the Court stated in Pacific Gas \& Electric Co. v. Public Utilities Commission of California:239 "The constitutional guarantee of free speech 'serves significant societal interests' wholly apart from the speaker's interest in self-expression.... The identity of the speaker is not decisive in determining whether speech is protected."240 Similarly, in First National Bank of Boston v. Bellotti, ${ }^{241}$ the Court stated: "The inherent worth of speech in terms of its capacity for informing the public does not depend upon the identity of its source, whether corporation, association, union, or individual."242 The logic of these cases applies with at least equal force to aliens. The first amendment should constrain all government action, whether that action affects citizens, resident, or temporary aliens; and whether those aliens are in the country or applying to enter. The first amendment should apply whenever to deny its application would "limit[] the stock of information from which members of the public may draw." 243

\section{Conclusion}

Read closely, Harisiades, Bridges, Rowoldt, Mathews, and Mandel combine to provide precedential support for a sensible exception to the plenary power doctrine. If the plenary power doctrine cannot be totally

$\$ 212(a)(28)$, there are probably those who would wish to meet and speak with him. The ideas of most such aliens might not be so influential as those of Mandel, nor his American audience so numerous, nor the planned discussion forums so impressive. But the First Amendment does not protect only the articulate, the well known, and the popular." Mandel, 408 U.S. at 768.

239. 475 U.S. 1 (1986) (plurality opinion) [hereinafter PG\&E].

240. Id. at 8 (quoting First National Bank of Boston v. Bellotti, 435 U.S. 765, 776 (1978)). As the court stated in ADC v. Meese, 714 F. Supp. 1060 (C.D. Cal. 1989), "Aliens in this country, like corporations or individuals, "contribute to the "discussion, debate, and the dissemination of information and ideas" that the first amendment seeks to further.' " Id. at 1078 (quoting PG\&E, 475 U.S. at 8, in turn quoting First National Bank of Boston v. Bellotti, 435 U.S. 765, 783 (1978)).

241. 435 U.S. 765 (1978) (overturning a state statute restricting corporate contributions to electoral campaigns).

242. Id. at 777 .

243. Id. at 783. For a general discussion of the "enrichment" or "collective right" theory of the first amendment, see Blum, The Divisible First Amendment: A Critical Functionalist Approach to Freedom of Speech and Electoral Campaign Spending, 58 N.Y.U. L. REV. 1273 (1983); Powe, Mass Speech and the Newer First Amendment, 1982 SuP. CT. REV. 243. 
abandoned, then it must at least accommodate an exception for first amendment challenges to the government's treatment of resident aliens. Furthermore, as suggested by Mandel's analysis, if not its precise holdmg, the exception should apply to all aliens, not just to those who are already in the United States. In any case, whether the plenary power doctrine is abandoned altogether or only when the first amendment is implicated, courts clearly have the power and duty to adjudicate the first amendment challenges presented in the remamder of this Comment.

III

\section{EXCEPTINg Resident Aliens AND PLO MEMBERs From SECTION 901: PRELIMINARY ABSTENTION ISSUES}

The current version of section 901,244 prohibiting the exclusion of most aliens for speech or activities that would be constitutionally protected for U.S. citizens, contains several exceptions. This Comment challenges the constitutionality of two of those exceptions: for members of the $\mathrm{PLO}^{245}$ and for resident aliens. ${ }^{246}$ The objection of this Comment is that the current version of section 901 allows PLO members or resident aliens to be deported or excluded for acts of expression or association that would carry no legal consequences for either U.S. citizens or nonimmigrant aliens. In the following sections, this Comment argues that to except PLO members and resident aliens from the benefits of section 901 violates the first amendment, including its equal protection component. 247

Part II of this Comment argued that the plenary power doctrine does not obstruct this challenge to section 901 for either of two reasons: (1) because the doctrine itself is no longer legitimate; or (2) because the doctrine does not apply to first amendment challenges. One aspect of that discussion continues here. In the discussion of rationales for the plenary power doctrine, this Comment argues that the doctrines of deference in foreigu affairs and abstention from political questions justify judicial deference only in certain cases. ${ }^{248}$ This Part argues, therefore, that a

244. Foreign Relations Authorization Act, Fiscal Ycars 1988 and 1989, Pub. L. No. 100-204, $\S 901,1987$ U.S. CODE CONG. \& ADMIN. NEwS (101 Stat.) 1331, 1399-1400 (codified at 8 U.S.C. $\S 1182$ note (Supp. V 1987)); amended by the Foreign Operations, Export Financing, and Related Programs Appropriations Act, 1989, Pub. L. No. 100-461, $\S 555,1988$ U.S. CodE CoNG. \& AdMIN. News (102 Stat.) 2268, 2268-36.

245. See supra note 77 and accompanying text.

246. See supra note 75 and accompanying text.

247. Both of the exceptions to section 901 challenged here present issues that can be framed either as first amendment or equal protection challenges. As explained infra at notes 296-299 and accompanying text, it would be redundant to present both challenges separately since the underlying issues are substantially similar. Therefore this Comment poses the issue as a selective denial of first amendment rights.

248. See supra notes $140-143$ and accompanying text. 
challenge to the section 901 exceptions is not a case in which either foreign affairs or political question deference is justified.

\section{A. The Political Question Doctrine}

The resident-alien and PLO exceptions to section 901 illustrate the inappropriateness of categorical political question abstention in immigration matters. Baker v. Carr ${ }^{249}$ provides the classic formulation of the political question doctrine. ${ }^{250}$ Applying the Baker analysis to the two exceptions demonstrates that judicial abstention is not appropriate.

Baker requires abstention if there is a "textually demonstrable constitutional commitment of the issue to a coordinate political department."251 As noted in Part II of this Comment, the Court has held that there is no textual commitment of the immigration power to any branch of government; the Court has merely inferred this power from the Constitution or, at times, from the concept of national sovereignty alone. ${ }^{252}$ Whatever the source of the federal immigration power, it is not textually committed to another branch, so as to prohibit the judiciary from reviewing the exercise of that power.

The Baker test also requires "a lack of judicially discoverable and manageable standards for resolving" the particular question. ${ }^{253}$ Since this Comment's constitutional challenge is based on the first amendment, an area to which the Court has devoted extraordinary attention, there

249. 369 U.S. 186 (1962).

250. The relevant passage states:

Prominent on the surface of any case held to involve a political question is found a textually demonstrable constitutional commitment of the issue to a coordinate political department; or a lack of judicially discoverable and manageable standards for resolving it; or the impossibility of deciding without an initial policy determination of a kind clearly for nonjudicial discretion; or the impossibility of a court's undertaking independent resolution without expressing lack of the respect due coordinate branches of government; or an unusual need for unquestioning adherence to a political decision already made; or the potentiality of embarrassment from multifarious pronouncements by various departments on one question.

Id. at 217.

251. Id.

252. See supra notes 131-138 and accompanying text. The fact that the immigration power is not found in the text of the Constitution makes it unnecessary to qualify the first Baker prong with the assumption that it means a textually demonstrable exclusive commitment to a coordinate political department. The statement in INS v. Chadha, 462 U.S. 919, 940-41 (1983), that the immigration power is found in the naturalization clause (U.S. CoNST. art. I, § 8, cl. 4), however, raises that issue. See supra note 181. Surely Baker does not hold that any power textually delegated to the legislature or the executive constitutes a political question. If it did, most judicial review would be prohibited. Thus, the first Baker prong must be read to require the exclusive commitment of the issues to a coordinate branch. Since textual support for the immigration power in the naturalization clause is ambiguous, the commitment of immigration issues to the other branches can hardly be described as exclusive; thus the first prong is not met. See T. AlEINIKofF \& D. MARTIN, supra note 4, at 8-9.

253. Baker, 369 U.S. at 217. 
is no lack of judicial standards for resolving the challenge. ${ }^{254}$ In Harisiades, the Court stated:

[It] is difficult to determine whether ambiguous speech is advocacy of political methods or subtly shades into a methodical but prudent incitement to violence. ... [T] Constitution enjoins upon us the duty, however, of distinguishing between the two. Different formulae have been applied in different situations and the test applicable to the Communist Party has been stated too recently to make further discussion at this time profitable. ${ }^{255}$

The "test applicable to the Communist Party" at that time was articulated in Dennis v. United States. ${ }^{256}$ Since 1952 the Court has developed and refined the various "formulae." The standard articulated in United States v. O'Brien ${ }^{257}$ for determining the validity of government action "incidentally" affecting first amendment freedoms provides a sufficiently "discoverable and manageable standard[]"258 for adjudicating the challenges posed here. Alternatively, the standard articulated im Brandenburg v. Ohio ${ }^{259}$ for regulation of subversive speech provides yet another "sufficiently discoverable and manageable standard."

Another Baker criterion asks if there is an "impossibility of deciding without an initial policy determination of a kind clearly for nonjudicial discretion."260 The Court has entertained first amendment and due process challenges in many politically sensitive situations involving highly politicized policy decisions. ${ }^{261}$ Thus, it is clear that "initial policy determinations" that require violation of first amendment interests are not immune from judicial review. Of course, this is not to say that any such

254. As Professor Legomsky states, "The procedural due process, Fifth Amendment "equal protection', and First Amendment arguments . . . are no more standardless when applied to immigration cases than they are when applied to other cases." S. LEGOMSKY, supra note 54, at 305.

255. 342 U.S. 580, 592 (1952) (citation omitted).

256. 341 U.S. 494 (1951), discussed at supra notes 202-205 and accompanying text.

257. 391 U.S. 367 (1968). The Court in O'Brien articulated its test as follows:

[W] think it clear that a government regulation is sufficiently justified if it is within the constitutional power of the Government; if it furthers an important or substantial governmental interest; if the governmental interest is unrelated to the suppression of free expression; and if the incidental restriction on alleged First Amendment freedoms is no greater than is essential to the furtherance of that interest.

Id. at 377 .

258. Baker v. Carr, 369 U.S. 186, 217 (1962).

259. 395 U.S. 444 (1969). The Court in Brandenburg stated that:

[T] he constitutional guarantees of free speech and free press do not permit a State to forbid or proscribe advocacy of the use of force or of law violation except where such advocacy is directed to inciting or producing imminent lawless action and is likely to incite or produce such action.

Id. (footnote omitted).

260. Id.

261. See, e.g., New York Times Co. v. United States, 403 U.S. 713 (1971) (prohibiting prepublication of the Pentagon Papers); New York Times Co. v. Sullivan, 376 U.S. 255 (1964) (libel action against critics of public official must show actual malice, not just falsity); Aptheker v. Secretary of State, 378 U.S. 500 (1964) (invalidating statute denying passports to members of 
legislation is automatically invalid, but only that it must withstand judicial scrutiny. The section 901 exceptions may well have been animated by policy decisions "of a kind clearly for nonjudicial discretion," for example, expressing opposition to the PLO. Nevertheless, the Court has shown itself unwilling to apply this prong of the Baker test so as to disable itself from reviewing such policies when first amendment rights are implicated.

The remaining Baker criteria are the "impossibility of a court's undertaking independent resolution without expressing lack of respect due coordinate branches of government; . . . an unusual need for unquestioning adherence to a political decision already made; [and] the potentiality of embarrassment from multifarious pronouncements by various departments on one question."262 Again, since the present challenges seek to vindicate first amendment challenges, none of these criteria applies.

To some extent, judicial review addressing individual civil liberties seems necessarily disrespectful and potentially embarrassing. However, such review is not really disrespectful if respect is not due. If the legislation in question violates an express fundamental constitutional guarantee, then the legislature does not deserve respect towards that legislation. When the actions of the coordinate branches have been challenged as violating the first amendment, the Court has chosen to take the risk of embarrassing those other branches. ${ }^{263}$ While such review might seem an einbarrassment to lawmakers, insistence that legislation accord with the first amendment can hardly constitute the type of embarrassment from which lawmakers should be shielded. ${ }^{264}$

Likewise, the exception for resident aliens provides no basis for requiring "unquestioning adherence to a political decision already made."265 Treating resident and nonimmigrant aliens equally will not create discontinuity in immigration policy, nor will it unsettle expectations. The question of whether or not to distinguish between the two types of aliens is no more "political" than many decisions that are made by the legislature and subject to judicial review.

For purposes of political question analysis the only thing that distinguishes the PLO exception from the resident-alien exception is that the

Communist organizations); Kent v. Dulles, 357 U.S. 116 (1958) (invalidating State Department regulations denying passports to members of Communist organizations). See infra notes 281-282.

262. Baker, 369 U.S. at 217.

263. See, e.g., cases cited supra note 261.

264. As stated in the context of an analogous situation, "[t] $]$ here is nothing undignified about respecting rights and powers granted in the Constitution." Note, State Sovereign Immunity Against Private Citizens, the Commerce Clause Power and the Supreme Court, 74 IowA L. Rev. 593, 613 (1989) (authored by Jake Holdreith).

265. Baker, 369 U.S. at 217. 
PLO exception involves emotional issues with strongly held and hotly contested views on both sides. However, Supreme Court decisions on controversial issues such as draft card burning, ${ }^{266}$ flag misuse ${ }^{267}$, abortion, ${ }^{268}$ and racial desegregation ${ }^{269}$ demonstrate that the Court does not equate "pohtical question" with "controversy."270 In Baker itself, Justice Brennan states this well: "The doctrine of which we treat is one of

266. United States v. O'Brien, 391 U.S. 367 (1968).

267. Texas v. Johnson, 57 U.S.L.W. 477 (U.S. June 21, 1989); Spence v. Washington, 418 U.S. 405 (1974).

268. Roe v. Wade, 410 U.S. 113 (1973).

269. Brown v. Board of Educ., 347 U.S. 483 (1954).

270. Noteworthy exceptions to this practice of not deferring in politically sensitive cases where personal liberty challenges are involved are the cases of Hirabayashi v. United States, 320 U.S. 81 (1943) (upholding curfew orders against Japanese-Americans during World War II), and Korematsu v. United States, 323 U.S. 214 (1944) (upholding military detention of Japanese-Americans regardless of suspicion of disloyalty). Although the Court did not characterize either decision as based on the political question doctrine, the minimal level of scrutiny applied to the issues in those cases amounted to an ad hoc exercise of political question deference. As Chief Justice Warren later wrote:

[Hirabayashi and Korematsu] demonstrate dramatically that there are some circumstances in which the Court will, in effect, conclude that it is simply not in a position to reject descriptions by the Executive of the degree of military necessity. Thus, in a case like Hirabayashi, only the Executive is qualified to determine whether, for example, an invasion is imminent.

To put it another way, the fact that the Court rules in a case like Hirabayashi that a given program is constitutional, does not necessarily answer the question whether, in a broader sense, it actually is.

Warren, The Bill of Rights and the Military, 37 N.Y.U. L. REV. 181, $192-93$ (1962).

The Court's statements in these two cases sound disturbingly applicable to the PLO exception at issue here. In Korematsu the Court quoted approvingly from Hirabayashi, stating:

Here, as in the Hirabayashi case, "... we cannot reject as unfounded the judgment of the military authorities and of Congress that there were disloyal members of that population, whose number and strength could not be precisely and quickly ascertained. We cannot say that the war-making branches of the Government did not have ground for believing that in a critical hour such persons could not readily be isolated and separately dealt with, and constituted a menace to the national defense and safety, which demanded that prompt and adequate measures be taken to guard against it."

Korematsu, 323 U.S. at 218 (citation omitted) (quoting Hirabayashi, 320 U.S. at 99).

These cases have never been repudiated by the Supreme Court and so must be treated as valid precedent. However, they can be casily distinguished from the legislation singling out PLO members for an exception to section 901 . First, these cases dealt with deference to the military in time of war, which presents the most extreme argument for judicial deference. Second, as in Zemel v. Rusk, 381 U.S. 1 (1965), and Regan v. Wald, 460 U.S. 222 (1983), discussed at infra notes 283-287 and accompanying text, the government action did not single out individuals based expressly upon expression, as does the PLO exception. Finally, as ignominious as it was, the Japanese internment was at least tailored expressly - though grotesquely overinclusively-to its goal, eliminating all Japanese-American spies from the general population. By contrast, the PLO exception, though equally over-inclusive, is not directiy tailored to either of its evident goals (pursuing foreign policy or interdicting terrorism), but only operates against those PLO members who for a separate, unrelated reason (ideological excludability) come within its reach. See infra notes 377-382 and accompanying text.

The more satisfactory treatment of these cases, however, is to acknowledge them for what they were-shameful exercises in wartime paranoia and racism, discredited by hindsight and subsequent developments in civil rights jurisprudence. Indeed, these cases bear important precedential valuebut not in the usual sense. Rather, they stand as a reminder of the critical importance of active 
'political questions,' not of 'political cases.' The courts cannot reject as 'no law suit' a bona fide controversy as to whether some action denominated 'political' exceeds constitutional authority."271 Given the nature of this Comment's challenges to section 901, the political question doctrine should not be employed to deny "the commendable and crucial task of judicial review in cases of individual constitutional liberties ... [where] the Court's participation is both vitally required and highly provocative."272

\section{B. Deference in the Conduct of Foreign Affairs}

A doctrine closely related to the political question doctrine holds that the judiciary should not intervene in cases involving the conduct of foreign affairs. ${ }^{273}$ However, it is difficult to argue that the exception to section 901 for resident aliens qualifies as crucial to the conduct of foreign affairs. Since the exception applies equally to nationals of every country, its use cannot contribute to the United States' pursuit of diplomatic policies and relations with other countries.

Furthermore, the Court's policy of abstention in matters of foreign affairs is intended primarily to protect the ability of the executive, not Congress, to act quickly and flexibly on the basis of confidential information, and to speak for the country with "one voice."274 Refusing to

judicial review of government action which singles out unpopular groups during times of tension and fear.

271. Baker v. Carr, 369 U.S. 186, 217 (1962). For a more thorough discussion of the political question doctrine, arguing that it is not a separate viable doctrine at all, see Henkin, Is There a "Political Question" Doctrine?, 85 Y ALE L.J. 597 (1976); or that it should be abandoned, see Redish, Judicial Review and the "Political Question," 79 Nw. U.L. REV. 1031 (1985); Tigar, Judicial Power, the "Political Question Doctrine," and Foreign Relations, 17 UCLA L. REV. 1135 (1970).

272. J. Choper, Judicial Review and the National Political Process 169 (1985); accord C. Wright, A. Miller \& E. Cooper, Federal Practice and Procedure $§ 3534$ (2d ed. 1984); Scharpf, Judicial Review and the Political Question: A Functional Analysis, 75 YALE L.J. 517, 583-87 (1966); Michelman, The Supreme Court, 1968 Term-Foreward: On Protecting the Poor Through the Fourteenth Amendment, 83 HARv. L. REv. 7, 69-71 (1969).

273. In Mathews v. Diaz, 426 U.S. 67 (1976), the Court stated:

For reasons long recognized as valid, the responsibility for regulating the relationship between the United States and our alien visitors has been committed to the political branches of the Federal Government. Since decisions in these matters may implicate our relations with foreign powers, and since a wide variety of classifications must be defined in the light of changing political and economic circumstances, such decisions are frequently of a character more appropriate to either the Legislature or the Executive than to the Judiciary. This very case illustrates the need for flexibility in policy choices rather than the rigidity often characteristic of constitutional adjudication. ... Any rule of constitutional law that would inhibit the flexibility of the political branches of government to respond to changing world conditions should be adopted only with the greatest caution.

Id. at 81 (footnotes omitted).

274. A seminal and oft-quoted statement of foreign relations deference was given by John Marshall in a speech to the House of Representatives in 1800, in which he said, "The President is the sole organ of the nation in its external relations, and its sole representative with foreign nations." 10 ANNALS OF CONG. 618 (1800), quoted in United States v. Curtiss-Wright Export Corp., 299 U.S. 
review Congress' decision to protect the free expression of some aliens but not others does not serve these interests.

Whether the Court should exercise foreign affairs deference with respect to the PLO exception requires a more complex analysis. Although not stated in the legislative history of section 901, other legislation suggests that the PLO exception was created at least partially for reasons of foreign policy. Evidently Congress wanted to express opposition to the PLO and support for its antagonist Israel. ${ }^{275}$ Thus, the sharp question is whether, in this case, the Court must abstain from reviewing the PLO exception to section 901 in deference to Congress' pursuit of foreign policy goals.

At first glance the PLO exception appears strikingly similar to the Iranian student cases that arose during the 1979 hostage crisis. Acting on a Presidential directive, the INS ordered all Iranian students to report

304, 319 (1936). A modern version of this doctrine is found in Narenji v. Civiletti, 617 F.2d 745 (D.C. Cir. 1979), cert. denied, 446 U.S. 957 (1980), where the court stated:

[I]t is not the business of courts to pass judgment on the decisions of the President in the field of foreign policy. Judges are not expert in that field and they lack the information necessary for the formation of an opinion. The President on the other hand has the opportunity of knowing the conditions which prevail in foreign countries, he has his confidential sources of information and his agents in the form of diplomatic, consular and other officials.

Id. at 748 (citations omitted).

For a discussion of the rationales underlying foreign relations deference and a thorough argument that foreign affairs deference is not appropriate for judicial review of statutes, see Note, The Boland Amendments and Foreign Affairs Deference, 88 CoLUM. L. REV. 1534, 1535-50 (1988) (authored by H.R. Wolohojian). For an argument that foreign affairs deference to executive action has been greatly overused, see Koh, Why the President (Almost) Always Wins in Foreign Affairs: Lessons of the Iran-Contra Affair, 97 YALE L.J. 1255 (1988).

275. See, for example, section 529 of the Foreign Operations, Export Financing, and Related Programs Appropriations Act, 1989, Pub. L. No. 100-461, § 529, 1989 U.S. CoDE CoNG. AND ADMIN. NEws (102 Stat.) 2268, 2268-27, entitled Prohibition Against United States Employees Recognizing or Negotiating with PLO, which states:

In reaffirmation of the 1975 memorandum of agreement between the United States and Israel, ... no employee of or individual acting on behalf of the United States Government shall recognize or negotiate with the Palestine Liberation Organization or representatives thereof, so long as the Palestine Liberation Organization does not recognize Israel's right to exist, does not accept Security Council Resolutions 242 and 338, and does not renounce the use of terrorism.

Id.

This legislation is evidence of the congressional purpose animating the PLO exception to section 901, even though on December 16,1988, PLO Chairman Yasser Arafat complied with these conditions and the United States agreed to meet with PLO representatives. See N.Y. Times, Dec. 16, 1988, at Al, col. 5 .

For additional discussion of foreign policy involving the PLO, see Harvard Law School Forum v. Shultz, 633 F. Supp. 525 (D. Mass. 1986), vacated without opinion, 852 F.2d 563 (1st Cir. 1986), in which the court stated:

The justification the Secretary offers for the denial of Terzi's travel request is that if the Secretary were to allow Terzi to participate in political activity outside of the limited area in which he is presently allowed to travel and publicly speak, he would be undermining the United States' policy of not lending legitimacy to the PLO.

Id. at 531 . 
to the INS, and made failure to report grounds for deportation. The INS also moved to deport all Iramian students who had violated technical visa requirements. ${ }^{276}$ When these cases reached the courts, the courts exercised deference because vital issues of foreign affairs were involved. ${ }^{277}$ However, closely comparing that situation with the PLO exception to section 901 reveals fundamental differences.

First, the Iranian student cases involved executive action as opposed to a congressional statute. The primary rationale behind foreign relations deference is to protect executive action. The interests of speed, flexibility, secrecy, and "speaking with one voice" that underlie the doctrine ${ }^{278}$ are not served by deference to legislative action, which is typically cumbersome, difficult to revise, and thrives on open debate. ${ }^{279}$

Secondly, the claims of the Iranian students were not based on the equal protection component of the first amendment. Rather, they asserted procedural due process arguments and equal protection claims (concededly factually correct) maintaining that they were expressly targeted for stricter treatment because of their national origin. ${ }^{280}$ Unlike aliens subject to the PLO exception, all Iranian students were singled out. The basis of their unequal treatment was not their individual political expression or association, nor did the INS reporting requirements stifle the political expression or association of the Iranian students. They simply were subject to heightened scrutiny of their conformity with their immigration status.

The first amendment provides a crucial basis for distinguishing between the present challenge to the PLO exception and the challenges

276. Narenji v. Civiletti, 617 F.2d 745 (D.C. Cir. 1979) (upholding INS regulations requiring Iranian students to report to INS and prove conformity with visa status), cert. denied, 446 U.S. 957 (1980); Yassini v. Crosland, 618 F.2d 1356 (9th Cir. 1980) (upholding INS decision to withdraw deferred departure status from certain Iranian students and to move to deport them); Shoaee v. INS, 704 F.2d 1079 (9th Cir. 1983) (upholding an Iranian student's deportation for overstaying the expiration of his visa).

277. Narenji, 617 F.2d at 748, quoted at supra note 274; Yassini, 618 F.2d at 1360 ("decisions involving the relationships between the United States and its alien visitors often implicate our relations with foreign powers and because of their political nature are generally more within the competence of the Legislative and Executive Branches than the Judiciary.").

278. "It would be intolerable that courts, without the relevant information, should review and perhaps nullify actions of the Executive taken on information properly held secret. . . [T] he very nature of executive decisions as to foreign policy is political, not judicial." Chieago \& S. Air Lines v. Waterman S.S. Corp., 333 U.S. 103, 111 (1948); see also sources cited supra note 274.

279. Indeed, the decision of the Reagan administration to begin direct negotiations with the PLO, discussed at supra note 275-a classic instance of flexible and discretionary conduct of foreign policy-demonstrates that the much more cumbersome legislative process embodied in the PLO exception may no longer reflect current U.S. policy towards the PLO. Arguably, such legislative activity actually takes away the executive's flexibility in changing U.S. relations with specific groups or states needed in foreign affairs.

280. Narenji, 617 F.2d at 747 (equal protection claim); Yassini, 618 F.2d at 1362-63 (procedural due process claim). 
to the deportation regulations in the Iranian student cases. Supreme Court jurisprudence on a closely related fundamental right-the right to travel-emphasizes this distinction. In Kent v. Dulles ${ }^{281}$ and Aptheker v. Secretary of State ${ }^{282}$ the Court struck down prohibitions on the right to travel that singled out certain U.S. citizens on the basis of their political beliefs or associations. In contrast, in Zemel v. Rusk ${ }^{283}$ and Regan v. Wald, ${ }^{284}$ the Court upheld blanket travel bans placed on all citizens that made no distinctions regarding belief, expression, or association. Both the Zemel and Wald opinions expressly distinguished their holdings from Aptheker, noting that the travel restriction in the latter case was limited to those who held certain political beliefs and associations. ${ }^{285}$ The Wald opinion, comparing the restriction under review with that upheld in Zemel, went on to note that, although the ban prevented travel to Cuba-thus constraming rights to information and opinion-"no First Amendment rights of the sort that controlled in Kent and Aptheker were implicated by the across-the-board restriction involved in Zemel." 286

Thus, the deference that the Court displayed in the Iranian student cases is inappropriate here. Unlike the Iranian student cases and Zemel and Wald, none of which involved action that discriminated against any particular content of expression or association, the PLO exception to section 901 targets one specific viewpoint as manifest by expressive association. In this regard the PLO exception is analogous to the legislation discriminating against Communist Party affiliates reviewed in Aptheker and Kent. ${ }^{287}$ As is clear from those opinions, deference need not be exercised in such cases.

281. 357 U.S. 116 (1958), overruled by Califano v. Aznavorian, 439 U.S. 170 (1978). Kent invalidated State Department regulations denying passports to Communists on the ground that the regulations exceeded the congressional grant of authority. The Court avoided the constitutional question but stated, "The right to travel is a part of the 'liberty' of which the citizen cannot be deprived without [fifth amendment due process]." Id. at 125 . While the opinion does not mention the first amendment, the Court did note, "We deal with beliefs, with associations, with ideological matters. . . . [These citizens] are being denied their freedom of movement solely because of their refusal to be subjected to inquiry into their beliefs and associations." Id. at 130.

282. 378 U.S. 500 (1964) (revocation of U.S. citizens' passports under Subversive Activities Control Act violates right to travel).

283. 381 U.S. 1 (1965) (upholding Secretary of State's power to bar travel to Cuba for most U.S. citizens).

284. 468 U.S. 222 (1984) (upholding regulations prohibiting all economic transactions with Cuba).

285. Zemel, 381 U.S. at 16; Wald, 468 U.S. at 241.

286. Wald, 468 U.S. at 241-42.

287. Another case raising the deference issue is Palestine Information Office (PIO) v. Shultz, 853 F.2d 932 (D.C. Cir. 1988), where the court upheld the State Department's closure of the PIO in Washington D.C. pursuant to the Foreign Missions Act, 22 U.S.C. \$\$ 4301-4316 (1982 \& Supp. IV 1986). The Act authorized the Secretary of State to order the closure of any foreign mission where the Secretary felt it "necessary to protect the interests of the United States." Id. at $\$ 4304(\mathrm{~b})(3)$. Employees of the PIO brought first amendment and due process challenges. The PIO opinion articulated strong foreign relations deference in upholding the closure. Like the Iranian students 
Some of the broadest statements of foreign affairs deference have been made in cases not involving fundamental individual rights. ${ }^{288}$ In cases involving fundamental individual rights, the Court has been willing to review actions taken under the foreign relations power. ${ }^{289}$ As the District Court in Allende v. Shultz ${ }^{290}$ stated, "[T]he Court has . . . emphasized that the government's power in [international relations] is not entirely immune from judicial scrutiny. . . . The exercise of judicial review, though necessarily limited in scope, is particularly appropriate in cases like the one at bar which involve fundamental rights of United States citizens."291 That section 901 imperils fundamental rights is confirmed by Kleindienst v. Mandel, ${ }^{292}$ in which the Court expressly articulated the rationale underlying "rights of the citizens of the country to have the alien enter and to hear him explain and seek to defend his views."293

United States v. Robel ${ }^{294}$ provides an example that is pertinent to the situation presented by the PLO exception. In Robel, the Court invalidated, on first amendment grounds, a statute aimed at reducing sabotage

cases, the challenged action was executive discretionary action-authorized by statute-that purported not to impinge directly on freedom of association. Indeed, the court expressly denied the application of its holding to a case in which the right of association was infringed. The court stated, "We are not cavalier about appellants' constitutional challenges and are mindful of the important free speech, free association and due process rights implicated by the Secretary's order. This order did not, however, infringe upon any of those constitutionally protected rights." PIO, 853 F.2d at 934.

The court also pointed out that the Secretary's letter ordering the closure of the PIO "stated explicitly that nothing in the Department's order was to interfere with 'the constitutionally protected rights of U.S. citizens and permanent residents who are now associated with the Palestine Information Office." "Id. at 939 (citations omitted) (quoting State Department letter, reprinted in Joint Appendix at 7).

288. See, e.g., Chicago \& S. Airlines v. Waterman S.S. Corp., 333 U.S. 103, 111 (1948) (in case involving airline regulation, Court stated that foreign policy decisions "are wholly confided by our Constitution to the political departments of the government"); Oetjen v. Central Leather Co., 246 U.S. 297, 302 (1918) (in case involving title to property seized during the Mexican Civil War, the Court stated, "The conduct of the foreign relations of our Government is committed by the Constitution to the Executive and Legislative-'the political'-Departments of the Government, and the propriety of what may be done in the exercise of this political power is not subject to judicial inquiry or decision.").

The Court has also made broad statements of foreign affairs deference in cases involving fundamental individual rights in the immigration area. See, e.g., Mathews v. Diaz, 426 U.S. 67, 81 (1976), quoted at supra note 273.

289. See, e.g., Aptheker v. Secretary of State, 378 U.S. 500 (1964), and Kent v. Dulles, 357 U.S. 116 (1958), discussed at supra notes 281 \& 282; see also New York Times Co. v. United States, 403 U.S. 713 (1971) (the Pentagon Papers case).

290. 605 F. Supp. 1220 (D. Mass. 1985).

291. Id. at 1223.

292. 408 U.S. $753,762-65$ (1972).

293. Id. at 764 (quoting the district court opinion, Mandel v. Mitchell, 325 F. Supp. 620, 631 (E.D.N.Y. 1971)). For a discussion of that rationale, see supra notes 221-228 and accompanying text.

294. 389 U.S. 258 (1967). 
and espionage by forbidding employment to members of the Communist Party in the nation's defense plants. Like the PLO exception, this classification operated against individuals without regard to whether the membership was actually connected to the evil the government was attempting to avoid. The Robel Court ignored a plea for deference to the statute on the ground that it was a matter of foreign affairs, instead stating, "[E]ven the war power does not remove constitutional limitations safeguarding essential liberties." "295 Similarly, the doctrine of deference in foreign relations does not require courts to abstain from reviewing this first amendment challenge to the section 901 exceptions.

The above discussion exhausts the threshold objections to a judicial review of the constitutionality of the resident-alien and PLO exceptions to section 901. Nothing stands in the way of judicial review: not the plenary power doctrine, nor the doctrine of deference in foreign affairs, nor the political question doctrine. Thus, the Court must determine whether the interests served by the section 901 exceptions justify the injury to the interests they harm.

\section{IV \\ VALIDITY OF SECTION 901's EXCEPTION FOR RESIDENT ALIENS \\ A. Nature of the Constitutional Challenge}

Having established that first amendment challenges to section 901 are not precluded by doctrines requiring deference to the legislature, the challenges themselves can be resolved by application of well-established constitutional principles.

Initially, it should be recognized that the essence of this challenge to section 901 is not that the first amendment protects resident aliens generally from deportation or exclusion based on expression. Such a challenge naturally follows from the conclusions of Part II of this Comment, but that argument has been made thoroughly and compellingly by others. ${ }^{296}$ Nor does the challenge involve the issue of what types of subversive or unpopular speech should be constitutionally protected for aliens. The argument in Part II of this Comment would require that the test articulated in Brandenburg v. Ohio ${ }^{297}$ dispose of that issue. Rather, this challenge is more focused: It asserts that the first amendment prohibits

295. Id. at 264 (quoting Home Bldg. \& Loan Ass'n v. Blaisdell, 290 U.S. 398, 426 (1934)). The call for judicial deference to the exercise of the war power is the strongest form of foreign affairs deference. The Court also stated that "the phrase 'war power' cannot be invoked as a talismanic incantation to support any exercise of congressional power which can be brought within its ambit." Id. at 263.

296. See supra note 29.

297. 395 U.S. 444 (1969) (per curiam). In Brandenburg, the Court overturned a criminal 
Congress from prescribing the Brandenburg test for nonresident aliens but not for resident aliens. The argument merely asserts that when Congress confers a benefit on aliens, protecting them from deportation based on expression, it cannot do so in a fashion that injures the first amendment interests of resident aliens and U.S. citizens unless the injury is necessary to achieve a compelling government interest and fashioned to achieved that interest in a minimally onerous way.

Thus, while this challenge focuses on discrimination-suggesting an equal protection argument ${ }^{298}$ - the discrimination also has the effect of denying full freedom of expression and association to resident aliens and U.S. citizens ${ }^{299}$ - suggesting a first amendment argument. Arguably, therefore, the exceptions to section 901 should be subjected to both equal protection and first amendment analyses. However, in spite of significant variations in the case law delineating the two constitutional clauses, the two analyses are substantially similar: they both weigh the competing interests and evaluate the "fit" between the legislative means and ends. ${ }^{300}$ Thus, since two separate analyses would be redundant, this Comment applies only one.

Because the equal protection analysis is not as certain to apply as

conviction of a leader of the Ku Klux Klan under the Ohio Criminal Syndicalism Act for making a speech at a Klan rally where he stated, "[I]f our President, our Congress, our Supreme Court, continues to suppress the white, Caucasian race, it's possible that there might have to be some revengence taken. . . . Personally, I believe the nigger should be returned to Africa, the Jew returned to Israel." Id. at 447. The Court overturned the statute, stating the now-famous rule that

the constitutional guarantees of free speech and free press do not permit a State to forbid or proscribe advocacy of the use of force or of law violation except where such advocacy is directed to inciting or producing imminent lawless action and is likely to incite or produce such action.

Id. (footnote omitted).

For an argument that the standard articulated in Procunier v. Martinez, 416 U.S. 396 (1974), is the appropriate standard for reviewing challenges to ideological exclusion, see Note, First Amendment, supra note 29, at 177-79. The Procunier test essentially modifies the test articulated in United States v. O'Brien, 391 U.S. 367, 377 (1968), quoted at infra text accompanying note 307. As paraphrased by the author of that Note, the Procunier test essentially requires that "first amendment freedoms be as complete as possible even where the state has strong interests in regulation." Note, First Amendment, supra note 29, at 178.

298. The equal protection clause of the fourteenth amendment was incorporated into the due process clause of the fifth amendment in Bolling v. Sharpe, 347 U.S. 497 (1954) aud thus applies to action by the federal government.

299. See supra notes $238-243$ and accompanying text.

300. The first amendment test primarily used in this Comment, provided by U.S. v. O'Brien, 391 U.S. 367 (1968), is a balancing test, as are equal protection tests (with varying degrees of requisite importance of government intersts). See, e.g., Police Dep't of Chicago v. Mosley, 408 U.S. 92 (1972); and cases cited infra at note 301. Brandenburg v. Ohio, 395 U.S. 444 (1969), however, did not use a balancing test, but rather employed a fiat prohibition on regulation of speech that is not "directed to inciting or producing imminent lawless action and is likely to incite or produce such action." Id. at 447. Since the balancing test presented by U.S. v. O'Brien presents more opportunity for justification of the exceptions to section 901 challenged here, this Comment uses that more lenient standard. See infra note 367 and accompanying text. 
the first amendment analysis is, this Comment applies the latter analysis. In this context, the equal protection analysis applies because of the doctrine that discrimination involving "fundamental rights" receives strict scrutiny. ${ }^{301}$ Clearly, freedom of expression and association are fundamental rights. However, the Supreme Court case law is increasingly inhospitable to "fundamental rights" cases, ${ }^{302}$ and the scholarly commentary reflects the extraordinary complexity of the relationship among equal protection, "fundamental rights," substantive due process, and democratic legitimacy of judicial review. ${ }^{303}$ By contrast, the language of the first amendment expressly prohibits government action that infringes the freedom of expression and association. ${ }^{304}$ Thus, reviewing section 901's discrimination against resident aliens under the first amendment is simply more straightforward than reviewing it under the fundamental rights component of the equal protection clause.

\section{B. Standard of Review: United States v. O'Brien}

Government action implicating flrst amendment rights has traditionally been reviewed under extremely close scrutiny, especially when the action selectively affects one group more than others. ${ }^{305}$ The constitutional evaluation that such close scrutiny entails varies significantly, however, depending on the fact pattern of the case. To scrntinize the

301. See, e.g., Eisenstadt v. Baird, 405 U.S. 438 (1972) (overturning on equal protection grounds convictions for violations of statute prohibiting distribution of contraceptives to single but not married people because it violated fundamental right of privacy); Shapiro v. Thompson, 394 U.S. 618,634 (1969) (invalidating a public welfare residency requirement as violating the "constitutional right [to travel], and any classification which serves to penalize the exercise of that right, unless shown to be necessary to promote a compelling governmental interest ...."); Skinner v. Oklahoma, 316 U.S. 535 (1942) (invalidating under equal protection clause selective criminal sterilization statute as violating fundamental right of procreation).

302. See, e.g., San Antonio Indep. School Dist. v. Rodriguez, 411 U.S. 1, 33 (1973) ("It is not the province of this Court to create substantive constitutional rights in the name of guaranteeing equal protection of the laws.").

303. See, e.g., Lupu, Untangling the Strands of the Fourteenth Amendment, 77 MICH. L. REV. 981, 983-84 (1979) ("liberty" and "equality" concepts hopelessly entangled in equal protection fundamental rights doctrine; fundamental rights aspect of equal protection applies only to those rights outside the first eight amendments); Perry, Equal Protection, Judicial Activism and the Intellectual Agenda of Constitutional Theory: Reflections on, and Beyond, Plyler v. Doe, 44 U. PITT. L. REV. 329, 336 (1983) (fundamental interest strand of equal protection judicial review is illegitimate).

304. U.S. CONST. amend. I. For a discussion of the freedom of association aspect of the first amendment, see infra note 359 and accompanying text.

305. See, e.g., Carey v. Brown, 447 U.S. 455, 463 (1980) (invalidating an ordinance prohibiting non-labor-related picketing of residences while allowing labor-related picketing; the Court held that discrimination in speech-related activities must be carefully scrutinized); Police Dep't of Chicago v. Mosley, 408 U.S. 92, 101 (1972) (invalidating an ordinance banning all school picketing except by labor union pickets, stating "the Equal Protection Clause requires that statutes affecting first amendment interests be narrowly tailored to their legitimate objectives.") See generally, Karst, Equality as a Central Principle in the First Amendment, 43 U. CHI. L. REV. 20 (1975). 
resident-alien exception to section 901, this Comment primarily employs the test developed in United States v. O'Brien, ${ }^{306}$ although, as will be seen, its application is not perfectly straightforward.

In O'Brien, the Court upheld a criminal conviction for the federal offense of draft card burning. The Court articulated a four-part test for evaluating legislation that regulates activity that is at once both speech and conduct:

[A] government regulation is sufficiently justified if it is within the constitutional power of the Government; if it furthers an important or substantial governmental interest; if the governmental interest is unrelated to the suppression of free expression; and if the incidental restriction on alleged First Amendment freedom is no greater than is essential to the furtherance of that interest. ${ }^{307}$

The $O^{\prime} B r i e n$ test is not limited to mediating the troublesome distinction between speech and conduct. More broadly stated, it evaluates legislation that purports to serve interests unrelated to expressive content but places "incidental limitations on First Amendment freedoms." ${ }^{308}$ Since the section 901 exception for resident aliens does not specify what speech or association makes them deportable, ${ }^{309}$ but simply exposes them to ideological deportation ostensibly in pursuit of other ends (such as antiterrorism), the O'Brien test applies. However, the O'Brien test fits this legislation only uncomfortably, so repeated reference is made to another test, employed in Brandenburg r. Ohio. ${ }^{310}$

This Part analyzes the resident-alien exception to section 901's prohibition against ideological exclusion and evaluates its constitutional validity by applying the four prongs of the O'Brien standard. Application of this test determines whether the regulation's effect on first amendment rights is, in fact, "incidental," and, if so, whether it is sufficiently

306. 391 U.S. 367 (1968). O'Brien upheld the conviction of an antiwar protestor for burning his draft card. While the facts concerned the speech versus conduct distinction, the Court characterized its analysis as a review of government regulation that places "incidental limitations on First Amendment freedoms." Id. at 376. Under a strict analysis, section 901 's effect on the free speech interests of resident aliens can hardly be characterized as "incidental" to combatting terrorism, since by withholding its benefits from resident aliens, section 901 openly permits the deportation or exclusion of resident aliens for the exercise of those free speech interests. Yet, less strictly analyzed, section 901 's effect on free speech interests can be seen as "incidental," since the apparent statutory purpose, the interdiction of terrorism, is not itself closely tied to free speech interests.

307. O'Brien, 391 U.S. at 377.

308. Id. at 376. Procunier v. Martinez, 416 U.S. 396, 411-12 (1974), holds that the O'Brien test is applicable to government actions creating "incidental restrictions on First Amendment liberties. . ." Procunier dealt with the restrictions on the first amendment rights of prisoners incidental to a mail inspection program designed to promote prison security.

309. If section 901 were to make resident aliens deportable because of the subject matter of their speech, then the Brandenburg test, supra note 297, would be appropriate.

310. 395 U.S. 444 (1969) (per curiam), discussed at supra note 297. 
tailored to ends that are important enough to justify the intrusion on expressive interests.

\section{Within the Constitutional Power of the Government}

In this, as in most challenges to government action under $O^{\prime} B r i e n$, the first prong serves primarily as throat-clearing. Congress clearly had the constitutional power to enact section 901 as a classification for determining who may enter and who may remain in the United States, and the power to specify who qualified for section 901 's protection from ideological exclusion. The Court recognized this power in The Chinese Exclusion Case ${ }^{311}$ and reaffirmed it as recently as 1983 in INS v. Chadha ${ }^{312}$ As the O'Brien test reveals, however, this is only the initial issue and is not dispositive of constitutional validity - an obvious point obscured by the plenary power doctrine. The Court stated this clearly in Chadha: "The plenary authority of Congress over ahens under [the naturalization clause] is not open to question, but what is challenged here is whether Congress has chosen a constitutionally permissible means of implementing that power."313

\section{Furthering an Important or Substantial Government Interest}

The government interest served by restricting section 90l's prohibition against ideological exclusion to nonimmigrants can be inferred from Senator Simpson's statement: "[W]e should not restrict the entry of visitors because of their beliefs .... However, permanent immigrants, those who can become citizens, should receive closer scrutiny." 314

Protecting nonimmigrants but not resident aliens reduces the risks to the United States that might result from the admission of undesirable aliens. Nonimmigrants are admitted for a limited, usually short, period of time. Resident aliens, by contrast, are admitted for an unlimited duration. They may work and receive some government benefits, and have the opportunity to apply for naturalization. ${ }^{315}$

But the government interest in giving "closer scrutiny" to resident aliens than to tourists and visiting workers must be defined more precisely. Before we can evaluate such a discrimination we must have some concrete idea of the type of undesirable qualities Congress was intending

311. 130 U.S. 581 (1889), discussed at supra notes 110-115 and accompanying text.

312. 462 U.S. 919 (1983), discussed at supra notes 174-183 and accompanying text.

313. Id. at $940-41$.

314. 134 CoNG. Rec. S13,800 (daily ed. Sept. 30, 1988), discussed at supra note 74 and accompanying text.

315. These considerations, however, militate against, not for, excluding immigrants from the benefit of section 901 . See infra note 350 and accompanying text. 
to screen out by submitting immigrant (resident) aliens to "closer scrutiny." Since the legislative record is opaque as to the object of Senator Simpson's and his colleagues' scrutiny, it must be conjectured. Two possible government interests suggest themselves. The government may be interested in retaining the unreviewable power to exclude resident aliens for expressing subversive, inflammatory, unorthodox, or even obnoxious views-or for associating with groups that do. Or, the government may wish to retain the power to exclude aliens-for ideological reasons alone-who are likely to commit terrorism or other dangerous acts. In this way, the government can avoid having to prove that the aliens actually pose such a threat. Each of these interests must be evaluated separately.

\section{a. Subversive Speech}

Assuming, arguendo, that the suppression of subversive or unpopular speech is the government interest behind section 901, there are two possible responses. First, O'Brien is not, then, the proper test since the exception to section 901 is not truly a regulation that is "incidental" to expression, but rather it is aimed directly at expression. Thus, the Brandenburg v. Ohio test should apply. ${ }^{316}$ As the Court stated in Spence v. Washington, ${ }^{317}$ when the government's interest is "directly related to expression the four-step analysis of United States v. O'Brien is inapplicable." 318

Applying the Brandenburg test to section 901's exception for resident aliens quickly demonstrates that the statute is invalid. Even if the continued application of the McCarran-Walter Act to resident aliens does suppress some offensive or inflammatory speech, clearly not all resident alien speech that falls under the Act is categorically "directed to inciting or producing imminent lawless action and ... likely to incite or produce such action."319 A statute will not pass the Brandenburg test unless it is far more narrowly tailored than the resident-alien exception to section 901, which sweepingly exposes all resident aliens to the risk of ideological exclusion.

Alternatively, the second response to the assertion that section 901 serves the government's interest in suppressing subversive or unpopular speech is to apply the O'Brien test. The second prong of that test

316. 395 U.S. 444 (1969), discussed at supra note 297.

317. 418 U.S. 405 (1982) (per curiam) (overturning a conviction for flag desecration).

318. Id. at 414 n.8.

319. Brandenburg, 395 U.S. at 447. The best example of this overinclusiveness is the arrest and attempted deportation of the Los Angeles Arab-Americans under various provisions of the McCarran-Walter Act, which would not have supported any proscription had the aliens been U.S. citizens. See supra note 24 and accompanying text. 
requires the court to evaluate the importance or substantiality of the government interest. ${ }^{320}$ Legislation that suppresses speech solely for its content (rather than for its effect, as in Brandenburg) without regard to whether the content is inflaininatory (rather than merely objectionable to soine lesser degree) does not further a legitimate-let alone importantgoverninental interest. Such a purpose directly contravenes the "profound national coinmitment to the principle that debate on public issues [be] uninhibited, robust, and wide-open, and that it [include] vehement, caustic, and sometimes unpleasantly sliarp attacks on government and public officials."321 Kleindienst $v$. Mandel ${ }^{322}$ makes clear that this "profound commitment" includes the contributions aliens make to such debate. Under prong one of the O'Brien test, ${ }^{323}$ therefore, this governinental interest is not sufficiently "important or substantial" to justify the suppression of the free-speech interests of aliens and citizens.

\section{b. Excluding Terrorists}

Another, more palatable, legislative motive for withholding from resident aliens the benefit of section 901 may be to reduce the likelihood that an admitted alien will coinmit an act injurious to national security or public safety. ${ }^{324}$ Reducing the risk that admitted aliens will coinmit acts of terrorism or other inalfeasance is undeniably an "important or

320. O'Brien, 391 U.S. at 377.

321. New York Times Co. v. Sullivan, 376 U.S. 254, 270 (1964); see also Associated Press v. United States, 326 U.S. 1, 20 (1945) (First amendment rests on the assumption that "the widest possible dissemination of information from diverse and antagonistic sources is essential to the welfare of the public...."). This commitment to tolerance of provocative expression is graphically illustrated in Cohen v. California, 403 U.S. 15 (1971), in which the Court overturned a conviction of a young man for wearing a jacket displaying the words, "Fuck the Draft." Describing this decision, Professor Ely has stated: "The dangers of censorship of both emotive and cognitive content, Justice Harlan suggested for the majority, must lead us to reject attempts to punish 'offensive language'; 'fighting words' are unprotected, but that category is no longer to be understood as a euphemism for either controversial or dirty talk but requires instead an unambiguous invitation to a brawl." Ely, Flag Desecration: A Case Study in the Roles of Categorization and Balancing in First Amendment Analysis, 88 HARV. L. REV. 1482, 1492-93 (1975).

322. 408 U.S. 753 (1972), discussed at supra notes 221-243 and accompanying text.

323. O'Brien, 391 U.S. at 377 (1969).

324. That "injurious" act could include spreading a contagious disease, becoming a public charge, forging currency, and so forth. However, since it is a fair assumption that terrorism was the prominent concern, this Comment, for purposes of economy, refers to this government interest as the interest in excluding terrorists.

Another possible reason for withholding section 901's benefits from immigrants, but not nonimmigrants, is that nonimmigrants have been the primary source of all the bad publicity surrounding ideological exclusion. In the last several years most negative press commentary on ideologieal exclusion has been in reaction to visa denials to prominent leftist political figures and intellectuals coming to visit or lecture in the United States. See supra note 37. Limiting the prohibition against ideological exclusion to nonimmigrants would dissipate that criticism and yet create the least change to the existing statutory structure. Reducing political "heat," however, cannot be considered a legitimate, let alone important, government interest. 
substantial government interest." ${ }^{325}$ It is also apparent that denying resident aliens the benefit of section 901 "furthers" that governmental interest. Restricting section 901 to individuals who are coming temporarily to the United States reduces the risk of admitting a terrorist, but only because any restriction on the scope of section 901 reduces that risk. Whenever the government allows a resident alien who has engaged in "subversive"-but constitutionally protected-speech or affiliation proscribed in INA subsections 212(a)(27), (28), and (29), ${ }^{326}$ there is a risk that that alien will act on his beliefs and commit an act of terrorism. The same would be true for nonimmigrant aliens applying to visit, work, or study in the United States. Indeed, the same is true for U.S. citizens. The fewer people there are to engage in subversive speech, the safer the United States is from terrorism and other destructive acts. But by mcreasing its safety in this way, the United States suffers a proportionate loss in the benefit that it receives from "uminhibited, robust, and wideopen" 327 debate on public issues. Whether that trade-off is justified is determined by applying the remaining prongs of the O'Brien test.

\section{Suppression of Free Expression}

The third prong of the O'Brien test requires that the "governmental interest [be] unrelated to the suppression of free speech . . .."328 This prong of the O'Brien test is problematic in that it seems to contradict the purpose of the test. If the function of the $O^{\prime} B r i e n$ test is to evaluate laws that affect speech at most incidentally, then a failure to satisfy the third prong would appear to indicate that the wrong test is being used. This anomaly can be rectified either by utilizing prong three as a "switching" device to signal that a different test is appropriate or, alternatively, as a mechanism for flushing out covert content-based legislative motives. In either case, this third prong weighs heavily against constitutionality in the ultimate balancing of all the $O$ 'Brien prongs.

\section{a. The "Switching" Function of the Third Prong}

Professor Ely asserts that the function of the third prong is not to determine the constitutionality of the challenged legislation but rather to determine if it is necessary to "switch" the analysis onto another track. ${ }^{329}$ Thus, somewhat improbably, he argues that the criterion for determining whether the O'Brien test should be used is buried within the test itself. If

325. O'Brien, 391 U.S. at 377.

326. 8 U.S.C. \$ $1182(\mathrm{a})(27)-(29)$ (1982), quoted at supra note 153.

327. New York Times Co. v. Sullivan, 376 U.S. 254, 270 (1964).

328. O'Brien, 391 U.S. at 377. Prosecuted for draft card burning, O'Brien argued that burning his card constituted "symbolic speech." Id. at 376.

329. Ely, supra note 321 , at 1484 . 
so, then the analysis is similar to the one applied above to determine the validity of a governinent interest in suppressing subversive speech. ${ }^{330}$ After being "switched" under the third prong, since it is clearly related to the suppression of free speech, the resident-alien exception to section 901 quickly fails the Brandenburg test.

Assurning, arguendo, that the government purpose underlying the resident-alien exception is to interdict terrorisin, then, strictly speaking, we cannot say that the governinent interest is the suppression of free speech. Yet, an analysis of the precise function of that exception, and section 901 itself, deinonstrates that the government interest is clearly related to the suppression of free speech.

Essentially, section 901 protects nonimmigrant aliens froin INA sections $212(\mathrm{a})(28)^{331}$ and $241(\mathrm{a})(6)^{332}$ which require the exclusion or deportation of aliens who either advocate various subversive doctrimes or affiliate with organizations that advocate those doctrines. These subsections proscribe not only advocacy of the violent overthrow of the governinent, but also advocacy of the destruction of property, ${ }^{333}$ the assaulting or killing of any officer of the governinent of the United States or of any other organized government, ${ }^{334}$ or the econoinic doctrines of world communisin. ${ }^{335}$ Under section 901, nonimmigrant aliens cannot be excluded or deported for such advocacy or affiliation unless that advocacy or affiiation satisfies the Brandenburg test. ${ }^{336}$ Yet the function of the residentalien exception is to permit thein to be excluded or deported for advocating such views as that the harbors of Nicaragua should be mined, that the Shah of Iran should be assassinated, or that coinmunism is a viable economic systern. Furthermore, resident aliens (but not nonimmigrant aliens) can be excluded or deported merely for belonging to an organization that advocates any of the above views whether or not they, themselves, have expressed such views.

The decision to exclude resident aliens from section 901 siguificantly limits the range of opinions that a resident alien nay safely express about conditions in her hoineland-whether that homeland is Nicaragua, El Salvador, Israel, Palestine, Iran, or Pakistan. Similarly, as the case of $A D C$ v. Meese $^{337}$ deinonstrates, resident ahens must be careful of the

330. See supra notes 316-319 and accompanying text.

331. 8 U.S.C. $\S 1182(a)(28)$ (1982), discussed at supra notes 49-55.

332. 8 U.S.C. $\S 1251$ (a)(6) (1982), discussed at supra notes 50-55.

333. INA $\S 212(\mathrm{a})(28)(\mathrm{F})(\mathrm{iii}), 8$ U.S.C. $\S 1181$ (a)(28)(F)(iii) (1982).

334. INA $\S 212(\mathrm{a})(28)(\mathrm{F})(\mathrm{ii}), 8$ U.S.C. $\$ 1181(\mathrm{a})(28)(\mathrm{F})(\mathrm{ii})$ (1982) (emphasis added).

335. INA § 212(a)(28)(D), 8 U.S.C. $§ 1181(\mathrm{a})(28)(\mathrm{D})$ (1982).

336. Brandenburg v. Ohio, 395 U.S. 444 (1969) (per curiam), discussed at supra note 297.

337. 714 F. Supp. 1060 (C.D. Cal. 1989), discussed at supra notes 19-26. 
organizations to which they belong because the McCarran-Walter provisions, unmodified by section 901 , contain no requirement that membership contribute to "imminent lawless action . . . likely to incite or produce such action."338

Conjecturally at least, Congress has chosen to interdict terrorism in this instance not by focusing on any indicator of terrorist activity or proclivities, but solely by expressly limiting free speech. Thus, the intent and effect of the resident-alien exception is to allow the government to deport or exclude resident aliens for expression that is constitutionally protected for citizens and-under section 901-for nonimmigrant aliens as well.

Accordingly, Professor Ely's "switching" function of the third $O$ 'Brien prong, requires that the balancing functions of the second and fourth prongs be abandoned in favor of more categorical tests like those in Brandenburg and Cohen v. California. ${ }^{339}$ Specifically, since the resident-alien exception suppresses "subversive" speech and association, Brandenburg applies.

Legislation permitting uncritical suppression of the kinds of speech described in the McCarran-Walter provisions cannot pass muster under Brandenburg because there is no requirement that a particular alien's expression be either intended to or likely to incite or produce "imminent lawless action." 340 The resident-alien exception, which permits the suppression of any "subversive" expression or association, is much too crude to satisfy the Brandenburg test.

\section{b. Flushing Out Covert Content-Based Suppression}

As an alternative to serving as a test-switching mechanism, the third prong of the $O$ 'Brien test may be used to probe further into the asserted government interest behind the legislation. Inquiring whether the government interest is "unrelated to the suppression of free speech"341 can serve either to flush out a covert attempt to suppress speech for the content of the speech or, similarly, to determine whether the regulation so heavily impinges on free speech that it cannot truly be said to be "incidental" to a content-neutral regulation. ${ }^{342}$ In either case, the analysis further informs the process of balancing the importance of the asserted non-speech-related governmental purpose (prong two) against the degree of intrusion on speech interests (prong four). In the case of the section

338. Brandenburg, 395 U.S. at 447.

339. 403 U.S. 15 (1951), discussed at supra note 321.

340. Brandenburg, 395 U.S. at 447.

341. United States v. O'Brien, 391 U.S. 367, 377 (1969).

342. See Bogen, Balancing Freedom of Speech, 38 MD. L. REv. 387, 401-02 (1979). 
901 exception for resident aliens, the balance leans away from the conclusion that the intrusion on the free speecl interests of resident aliens is sufficiently "incidental" or innocent of speech-suppressive intent to be justified.

As demonstrated in the discussion above, ${ }^{343}$ the resident-alien exception to section 901 has the direct-and primary-effect of suppressing the free speech of all resident aliens. Eitlier of two conclusions can be drawn from this observation: (1) the purported anti-terrorist purpose of the resident alien exception is simply a "cover" for the legislature's true intent to suppress the free speech of resident aliens; or, more charitably, (2) the legislature truly did intend to stifle terrorism by allowing resident aliens to be deported or excluded on ideological grounds. In order to draw the second conclusion, however, one must confront the obvious fact that only a tiny percentage of resident aliens are terrorists, yet the exception clills the free expression of all resident aliens. In slort, the tail is wagging the dog. The "incidental" suppression of free speech overwhelms the innocent purpose of expelling terrorists.

In sum, the suppression of free speech is either an innocent consequence of an overly broad statute with a legitimate purpose, or it is the covert true purpose of the statute. In either case, $O^{\prime} B r i e n ' s$ third prong demonstrates at least that the resident-alien exception requires weighty justification in order to meet the balancing tests of the other prongs. Alternatively, if this exception to section 901 is indeed covertly designed to suppress the free speecli of resident aliens, then the O'Brien test does not apply, and the provision fails under the Brandenburg test. ${ }^{344}$

\section{No Greater Restriction than Essential}

Depending on one's interpretation, the O'Brien test's third prong either disposes of the constitutionality of the resident-alien exception, or it sends the evaluation of the exception to the fourth prong with a suspicion of unconstitutionality. The fourth and final prong of the O'Brien test inquires whether the "incidental restriction on alleged First Amendment freedoin is no greater than is essential to the furtlierance of that interest." 345 Thus, prong four looks at the legislation's efficiency in furthering the government interests identified in prong two.

Evaluated under the fourth prong, the resident-alien exception's restriction of first amendment interests is plainly greater than necessary to aclieve its apparent legitimate purposes. Altlough the exception's restriction of free speecl furthers the government purpose in a purely

343. See supra notes $332-338$ and accompanying text.

344. Brandenburg, 395 U.S. at 447.

345. O'Brien, 391 U.S. at 377. 
mathematical and arbitrary way, it does not do so in a minimally onerous fashion. Minimizing the risk of admitting terrorists by allowing ideological exclusion for all resident aliens is extravagantly overinclusive. Since it does nothing to single out terrorists, the resident-alien exception permits the exclusion of both terrorists and nonterrorists. ${ }^{346}$ In short, the "means-ends" fit is extremely loose.

Furthermore, the application of section 901 to nonimmigrants but not to resident aliens is counter-intuitive. It discriminates against resident aliens, who have traditionally been deemed worthy of heightened constitutional protection, ${ }^{347}$ in favor of nonimmigrant aliens, who have been given no constitutional protection when applying from abroad ${ }^{348}$ and minimal protection when in the United States. ${ }^{349}$ In short, aliens who have never visited or are temporarily visiting the United States receive the same constitutional protection as U.S. citizens, but aliens who have acquired lawful permanent residence status do not.

If the goal is to increase the odds of interdicting terrorists, and the means chosen to achieve that end are to allow ideological exclusion of a class of aliens, then it would appear that this goal would be better achieved by selecting nonimmigrant aliens, rather than resident aliens. There is no reason to believe that a resident alien is more likely than a tourist or a student to perpetrate a terrorist act. Indeed, the reverse seems more likely. Common sense suggests that someone who would commit an act of terrorism would likely come to the United States from abroad to do so. Moreover, the process of acquiring immigrant status is much more selective and lengthy than the process of acquiring a nonimmigrant visa. ${ }^{350}$ Thus, would-be immigrant resident-alien terrorists are more likely to be screened out than their student and tourist counterparts. Furthermore, a resident alien bent on committing a terrorist act in

346. Clearly the vast majority of resident aliens are neither terrorists nor any other variety of undesirable immigrant. Or, more precisely, even the vast majority of resident aliens who have engaged in the kind of activities described in sections 212(a)(27)-(29) of the McCarran-Walter Act, 8 U.S.C. §1182(a)(27)-(29) (1982), discussed at supra note 49, and are therefore susceptible to ideological exclusion, arc neither terorrists nor any other variety of undesirable immigrant.

347. Graham v. Richardson, 403 U.S. 365,372 (1971) (characterizing resident aliens as deserving heightened judicial scrutiny because they meet the indicia of a discrete and insular minority).

348. See, e.g., Kleindienst v. Mandel, 408 U.S. 753, 762 (1972) ("It is clear that Mandel personally, as an unadmitted and nonresident alien, had no constitutional right of entry to this country as a nonimmigrant or otherwise.").

349. See, e.g., Mathews v. Diaz, 426 U.S. 67 (1976), discussed at supra notes 90, 217; Narenji v. Civilletti, 617 F.2d 745 (D.C. Cir.), cert. denied, 446 U.S. 957 (1980); Yasini v. Crosland, 618 F.2d 1356 (9th Cir. 1980). The latter two cases are discussed supra at notes 276-277 and accompanying text.

350. T. AlEINIKofF \& D. MARTIN, supra note 4, at 97-103, 271-76. For example, a grant of immigrant status usually requires an FBI check of fingerprints, and, in many cases, submission of police records from each country in which the applicant has lived for more than six months. 
the United States is much more likely than a short-term visitor to run afoul of the many domestic laws aimed at preventing and pumishing such acts. $^{351}$ Finally, the longer an alien is a member of the U.S. national commumity, the more likely she is to acquire intimate associations and feelings of commitment or loyalty which would counter the motivation to commit terrorism.

The point of $O^{\prime}$ Brien is that if the legislature wishes to interdict terrorism, it must craft legislation that is specifically addressed to that end. Excepting resident aliens from statutory protection agamst ideological exclusion does not specifically address the reduction of terrorism. The fact that section 901 has a separate provision addressimg terrorism, section 901(b)(2), ${ }^{352}$ underscores the overreaching of the resident-alien exception. Given the statutory definition and the accompanying Conference Committee Report, ${ }^{353}$ the "terrorist activity" exception is carefully tailored, since it allows the ideological exclusion or deportation of only those aliens suspected to be hkely to commit a terrorist act. ${ }^{354}$ In comparison, the resident-ahien exception is a blunt instrument, poorly tailored to any conceivable legitimate end; thus, it clearly violates the first amendment.

\section{$\mathrm{V}$}

\section{The VALIDITY OF THE PLO EXCEPTION}

As noted above, ${ }^{355}$ the benefits of section 901 are expressly withheld from members of the PLO. ${ }^{356}$ This Part argues that the PLO exception

351. All of the following statutes make terrorist activity illegal: 18 U.S.C. $\$ \S 792-799$ (1982 \& Supp. IV 1986) (espionage); id. $\$ 831$ (1982) (certain transactions involving nuclear materials); id. $\$ \$ 841-847$ (1982 \& Supp. II 1984) (importation, manufacture, distribution, and storage of explosives); id. §§ 1651-1661 (1982) (piracy); id. \$§ 351, 1751 (1982 \& Supp. IV 1986) (kidnaping and assassination of members of Congress, Supreme Court justices, and the President); id. ch. 105, $\S \S 2151-2157$ (1982 \& Supp. II 1984) (sabotage); id., \$§ 2381-2391 (1982 and Supp. II 1984) (treason, sedition, and subversive activities); 49 U.S.C.A. app. $\$$ 1472(i)-1472(1)(c) (West Supp. 1989) (terrorist acts abroad against U.S. nationals).

352. Foreign Relations Authorization Act, Fiscal Years 1988 and 1989, Pub. L No. 100-204, $\S$ 901(b)(2), 1987 U.S. CODE CONG. \& ADMIN. NEwS (101 Stat.) 1331, 1399-1400 (codified at 8 U.S.C. $§ 1182$ note (Supp. V 1987)), quoted at supra note 76.

353. CONFERENCE REPORT, supra note 68 , at 165 , discussed at infra note 373 and accompanying text.

354. Still, the terrorist activity exception is anomalous. The terrorist exception is not a ground of exclusion for aliens suspected of terrorist propensities; rather, it is an exception to a prohibition against ideological exclusion. As such, it is unnecessary because suspect terrorists are already excludable or deportable under existing provisions of the INA, $\S \S 212(\mathrm{a})(27)$ or (29), quoted at supra note 49. See also, infra note 382. Furthermore, the terrorist exception is underinclusive because it does not apply to all aliens suspected of terrorist propensities, but only to those aliens so suspected who are also excludable for their ideology.

355. See supra note 77.

356. This Comment addresses only the portion of the PLO exception that excludes "members" of the PLO. The rest of the PLO exception, including officers, representatives, and spokesmen of the 
violates the first amendment guarantees of free expression and association. In effect, section 901 subjects the members of no other group in the world-including other "terrorist" groups, such as the Irish Republican Army, the Stern Gang, the Red Brigade, or Hezbollah-to deportation or exclusion based solely on expression or association unless justified by the test imposed by Brandenburg $v$. Ohio. ${ }^{357}$ Under the PLO exception, however, PLO members can be deported or denied visas solely on the basis of their affiliation with the PLO, without regard to whether their conduct or expression violated any constitutional standard or whether there is any suspicion that terrorist activity is likely. Thus, the PLO exception is a legislative classification based solely on expressive association, regardless of conduct.

\section{A. First Amendment Interests Implicated}

The preliminary inquiry of any first amendment analysis is to determine whether the challenged statute actually infriges upon first amendment interests. ${ }^{358}$ Freedom of association is firmly established as a fully protected component of the first amendment's protection of free expression. ${ }^{359}$ The PLO exception clearly infringes upon the first amendment

PLO, presents a more difficult case because involvement with the PLO may involve culpable conduct as well as mere association. By contrast, a classification based upon membership is solely and expressly associational.

When section 901 originally applied to all aliens, the PLO exception likewise applied to all aliens-both immigrant and nonimmigrant. Since section 901 was amended to permit the exclusion of immigrant aliens, the scope of the PLO exception diminished accordingly. See supra notes 66, 74 75 and accompanying text. It now applies only to nonimmigrant members of the PLO. Immigrant alien PLO members are excluded from section 901 simply by virtue of their status as immigrants. Since this Comment challenges the two restrictions separately, the challenge to the PLO exception is made as if it included all aliens, on the assumption that the unconstitutionality of the immigrant restriction is demonstrated elsewhere in this Comment.

357. 395 U.S. 444 (1969), discussed at supra note 297. Members of these other groups can, of course, be excluded for suspicion of terrorist activity under section 901(b)(2), but that exception, though considerably looser than the Brandenburg test, is meticulously limited to terrorist activity, not expression or association. See infra notes 383-385 and accompanying text.

358. Although the necessity of initially identifying the first amendment interests seems obvious, it is not often expressly articulated in the case law. That such an identification is necessary is implied, however, in the O'Brien test, which requires in prong four that the "incidental restriction on alleged First Amendment freedoms is no greater than is essential to the furtherance of [the government] interest." United States v. O'Brien, 391 U.S. 367, 377 (1969) (emphasis added). The identification of those "alleged First Amendment freedoms" is thus necessary to initiate first amendment scrutiny.

359. Roberts v. United States Jaycees, 468 U.S. 609, 622 (1984) (The Supreme Court has "long understood as implicit in the right to engage in activities protected by the First Amendment a corresponding right to associate with others in pursuit of a wide variety of a wide variety of political, social, economic, educational, religious, and cultural ends."); NAACP v. Alabama ex. rel. Patterson, 357 U.S. 449, 460 (1958) ("Effective advocacy of both public and private points of view, particularly controversial ones, is undeniably enhanced by group association, as this Court has more than once recognized by remarking upon the close nexus between the freedoms of speech and assembly."); see also Healy v. James, 408 U.S. 169, 186 (1971) (" 'Guilt by association alone, without [establishing] 
interests of aliens who are members of the PLO, since the exception expressly permits ideological exclusion or deportation on the basis of membership alone under the McCarran-Walter Act. ${ }^{360}$ Likewise, aliens who are even considering membership in the PLO do so at similar risk. In view of the ambiguous nature of "membership" in the PLO, ${ }^{361}$ aliens should be concerned about associating with any group that advocates any form of Palestinian nationalism. In any case, aliens who are members of the PLO or are considering membership are subject to deportation, an extreme sanction, solely for expressing their political beliefs through speech or association. A "chilling effect" on these aliens' expression is a modest metaphor for the effect of the PLO exception.

Furthermore, the interest of U.S. citizens in meeting and talking with members of the PLO is injured. As the Court made clear in Kleindienst v. Mandel, ${ }^{362}$ the benefits of face-to-face contact with aliens is an essential part of the right to receive ideas, so important to a vigorous democracy. ${ }^{363}$ If development of a well-considered U.S. policy towards the Mideast depends on "uninhibited, robust, and wide-open" debate, ${ }^{364}$ then participation in that debate by members of the PLO is essential. Ejecting them from that debate disserves the need to hear the whole range of opinion on that crncial issue. In short, the first amendment interests of both aliens and U.S. citizens are injured by the PLO exception. Whether that injury is constitutionally justified is determined by application of well-established first amendment principles.

\section{B. The Standard of Review: O'Brien}

In the previous discussion of the resident alien exception to section 901, the O'Brien test appears to be a cumbersome and inelegant vehicle

that an individual's association poses the threat feared by the Government,' is an impermissible basis upon which to deny First Amendment rights." (quoting United States v. Robel, 389 U.S. 258, 265 (1967)); Robel, 389 U.S. at 263 n.7 ("Our decisions leave little doubt that the right of association is specifically protected by the First Amendment." (citations omitted)).

350. INA $\S 212(a)(28)(F)(i i i), 8$ U.S.C. $\S 1181$ (a)(28)(F)(iii) (1982) (exclusion grounds); INA $\S 212(\mathrm{a})(28)(\mathrm{F})(\mathrm{ii}), 8$ U.S.C. $\S 1181$ (a)(28)(F)(ii) (1982) (deportation grounds). Both provisions are discussed at supra notes 49-55 and accompanying text. As discussed infra at notes 377-382 and accompanying text, the PLO exception does not allow the deportation of PLO members because they are members of the PLO. It does, however, subject PLO members to deportation for otherwise constitutionally-protected expression and association. As such, it doubly infringes upon their first amendment interests. First, it permits this group to be charged under a statute authorizing deportation and exclusion on the basis of association. Secondly, the group itself is defined according to an associational criterion-membership in the PLO.

361. See infra note 414 .

362. 408 U.S. 753 (1972).

363. See supra notes 223-227 and accompanying text.

364. New York Times Co. v. Sullivan, 376 U.S. 254, 270 (1964). 
for evaluating exceptions to section 901; the Brandenburg approach necessarily intrudes at several points. ${ }^{365}$ The PLO exception straddles even more uncomfortably the differing situations that O'Brien and Brandenburg were designed to address. On the one hand, Brandenburg's categorical approach seems appropriate since the PLO exception itself is framed as a statutory discrimination against a specific political association and a specific political viewpoint-a classic case of content-based suppression. If the test in Brandenburg (or Cohen v. California ${ }^{366}$ ) applies, the PLO exception must be invalidated, unless the government can demonstrate that all PLO members harbor the specific intent and capability to incite imminent lawless activity.

On the other hand, section 901's legislative history suggests that the PLO exception apparently furthers non-speech-related government concerns. Furthermore, the PLO exception does not, itself, directly proscribe free expression; rather, it allows the continued practice of ideological exclusion under the McCarran-Walter Act for PLO members. This suggests that perhaps the consequent suppression of free speech is "incidental" to legitimate interests and that $O$ 'Brien's balancing test should be applied. The O'Brien test is more lenient than the Brandenburg test because it weighs the importance of the government interests, the law's effect on free speech, and the law's efficiency in achieving those interests. Thus, it contemplates the possibility that suppression of free speech may be justified. In contrast, the Brandenburg test does not balance the importance of the government's interest against the suppression of speech, but considers only the intent, imminence, and likelihood of violence of the speech (or association) in question.

The above discussion of the resident-alien exception was an exercise in shuttling back and forth between these two tests. The evaluation of the PLO exception applied below simply applies the more lenient $O$ 'Brien test on the assumption-demonstrated by the result of O'Brien itself ${ }^{367}$ - that if the PLO exception fails the O'Brien test, then it surely fails the Brandenburg test as well. ${ }^{368}$

365. See supra notes 318-319 \& 329-340 and accompanying text. For additional background, see generally Ely, supra note 321.

366. 403 U.S. 15 (1971), discussed at supra note 321.

367. The regulation in $O^{\prime} B r i e n$ prohibiting destruction of draft cards was uphcld, yet therc was no suggestion that such destruction was animated by a specific intent to provoke imminent violence or that it was likely to do so.

368. The constitutional validity of the PLO exception has already been evaluated under a "rational basis" standard of review, with the result that it was held unconstitutional. That decision, however, was superseded by later developments in the same case. ADC v. Meese, 714 F. Supp. 1060 (C.D. Cal. 1989), discussed at supra note 187.

Before Judge Wilson issued his final opinion in $A D C v$. Meese, holding the ideological exclusion of aliens in the United States unconsitutional on its face, he issued an Outline of Decision of the Merits (Dec. 22, 1988) [hereinafter Outline] (on file with the author). In this Outline, hc held 
As noted above, ${ }^{369}$ the $O^{\prime}$ Brien test asks four questions: (1) Is the regulation within the government's power? (2) Does it further an important or substantial government interest? (3) Is that interest unrelated to suppression of free expression? and (4) Is the regulation narrowly tailored to attain the government interest? Each of these questions will be discussed in turn.

\section{Within the Government's Power}

For the reasons stated above, ${ }^{370}$ Congress clearly has the power to make substantive classifications to determine which aliens may receive certain immigration benefits. Therefore, the PLO exception meets the first $O^{\prime} B$ rien criterion. ${ }^{371}$

\section{Furthering an Important or Substantial Government Interest}

To answer the second question of the O'Brien test- "Does the regulation further an important or substantial government interest?"372 - two things must be determined: (1) What are the government interests motivating the law? and (2) Does the law actually further those interests?

The Conference Committee Report accompanying section 901 does not mention the PLO exception except to recite its language. ${ }^{373}$ Other sources, however, indicate that its primary purpose is to exclude terrorists. ${ }^{374}$ Additionally, the PLO exception probably serves the purpose

ideological exclusion under the McCarran-Walter Act unconstitutional, but only as applied to resident aliens, not nonimmigrant aliens in the United States. Outline at 4 . Thus, for resident aliens, section 901 was superfluous.

Because the ideological exclusion provisions remained applicable to nonimmigrants, so too did the section 901 prohibition against ideological exclusion. In evaluating what remained of section 901 , Judge Wilson held that the first amendment does not apply to nonimmigrants, but that a "rational basis" standard of review applies to legislation affecting them. Id. at 5 . He then found that the PLO exception is "not rationally related to a legitimate government end and violates the Fifth Amendment's due process equal protection component." Id. at 6.

In his final opinion, Judge Wilson modified his Outline opinion to expand his original holding to include all aliens within the United States regardless of whether they are nonimmigrants or resident aliens. ADC v. Meese, $714 \mathrm{~F}$. Supp. at 1074-75. Thus, his Outline's analysis of the validity of the PLO exception to section 901 was superseded. See id. at 1084 n.19.

While Judge Wilson's analysis reaches the same result as urged here, this Comment contends that the appropriate standard of review of first amendment challenges, whether for resident aliens or nonimmigrant aliens, should be the same heightened scrutiny as that applied for U.S. citizens. See supra notes 231-237. But it is instructive for the analysis here that the PLO exception has been found to be constitutionally invalid even under a mere "rational basis" standard.

369. See supra text accompanying notes 306-307.

370. See supra notes $311-313$ and accompanying text.

371. United States v. O'Brien, 391 U.S. 367, 377 (1968).

372. Id.

373. CONFERENCE RePORT, supra note 68 , at 165.

374. Title $X$ of the same Act that contains the original section 901 includes an explicit congressional finding that "the PLO and its affiliates are a terrorist organization and a threat to the interests of the United States." Foreign Relations Authorization Act, Fiscal Ycars 1988 and 1989 
of expressing a congressional statement of foreign policy: opposition to the PLO and support for its antagonist Israel. ${ }^{375}$ The former purpose, to interdict terrorism, is obviously an important and substantial government interest, as required by United States v. O'Brien. ${ }^{376}$ Similarly, Congress' interest in furthering its foreign policy objectives is also undoubtedly important and substantial.

Thus, the PLO exception is, no doubt, intended to pursue important and substantial government interests. For this prong of the O'Brien text to be meaningful, however, the inquiry must proceed further and determine whether the challenged legislation actually furthers those interests. These two interests will now be evaluated, in turn, for an assessment of their utility. The following conclusions will be drawn: Viewed in conjunction with the rest of section 901, the PLO exception does not substantially further the goal of interdicting terrorism. On the other hand, the PLO exception clearly furthers Congress' interest in making statements of foreign policy. The remaining $O^{\prime} B r i e n$ prongs, however, question the constitutionality of Congress' pursuit of foreign policy through legislation that discriminates against PLO members.

\section{a. The Interest in Interdicting Terrorism}

To some extent at least, permitting the ideological exclusion or deportation of PLO members does further the goal of interdicting terrorists. But it does so only in the same arbitrary and random manner deemed illegitimate in the above discussion of the resident-alien exception. ${ }^{377}$ Any restriction on entry reduces the risk of admitting terrorists by simply reducing the number of potential terrorists. But as a scheme intended to interdict terrorists, it is both underinclusive and overinclusive. It is overinclusive because the exception applies to all PLO members without any requirement that there be some suspicion of individual propensity to commit a terrorist act. It is underinclusive because it

(FRAA), Pub. L. No. 100-204, Title X, § 1001, 1987 U.S. CODE CONG. \& ADMIN. News (101 Stat.) 1331, 1406-07 (codified at 22 U.S.C. $\S 5201$, (Supp. 1989)). Section 1003 of the FRAA, 22 U.S.C. $\S 5202$, goes on to make it unlawful

(1) to receive anything of value except informational material from the PLO or any of its constituent groups, any successor thereto, or any agents thereof;

(2) to expend funds from the PLO or any of its constituent groups, any successor thereto, or any agents thereof; or,

(3) notwithstanding any provision of law to the contrary, to establish or maintain an office, headquarters, premises, or other facilities or establishments within the jurisdiction of the United States at the behest or direction of, or with funds provided by the Palestine Liberation Organization .... .

375. See supra note 275 and accompanying text.

376. 391 U.S. 367,377 (1968).

377. See supra text accompanying note 324. This apparent "arbitrariness" is further delineated by the existing anti-terrorism provision of section 901, discussed infra at notes 382.384 and accompanying text. 
applies only to meinbers of the PLO, leaving the members of other "terrorist" groups unaffected.

Furthermore, the statutory function of the PLO exception does not suggest that it was designed to interdict terrorisin. The PLO exception does not inake membership in the PLO a deportable offense. Rather, the PLO exception is an exception to section 901's general prohibition against ideological exclusion. As Judge Wilson stated in the preliminary Outline $^{378}$ to his decision in $A D C$ v. Meese, ${ }^{379}$

If Congress was using PLO membership as the equivalent for terrorism, the PLO Exception does not rationally relate to that interest. . . . Congress has not made PLO membership in itself a deportable offense. Only PLO members who also advocate the prohibited McCarran-Walter ideas can be deported. PLO members who stay silent or introverted or advocate Chicago School economics or affiliate with the John Birch Society may stay within the country's borders.

... Thus, we conclude that the PLO Exception is not rationally related to a legitimate government end and violates the Fifth Amendment's due process equal protection component. ${ }^{380}$

Section 901(a) only prohibits exclusion for "beliefs, statements or associations which, if engaged in by a United States citizen in the United States, would be protected under the Constitution"381 and it is from that prohibition that members of the PLO are excepted. The exception clearly does not augment existing McCarran-Walter Act authority to exclude aliens for terrorist activity. ${ }^{382}$ Since exclusion for terrorism can be accomplished without an exception to section 901(a), the PLO exception seeins superfluous. Furthermore, this superfluity is rendered even more pronounced in view of an express and detailed exception for terrorist activity in section 901(b).

Intending to exclude terrorists and potential terrorists from the prohibition against ideological exclusion, Congress provided a broad exception to section 901(a):

Nothing in this section shall be construed as affecting the existing

378. See supra note 368 .

379. 714 F. Supp. 1060 (C.D. Cal. 1989).

380. Outline, supra note 368 , at 6.

381. Foreign Relations Authorization Act, Fiscal Years 1988 and 1989 (FRAA), Pub. L. No. 100-204, $\S 901$ (a), 1987 U.S. CODE CONG. \& ADMIN. NEws (101 Stat.) 1331, 1400 (codified at 8 U.S.C. $\$ 1182$ note (Supp. V 1987) (Prohibition on Exclusion or Deportation of Aliens on Certain Grounds)).

382. Suspicion of past or future terrorist activity is clearly a ground of exclusion under INA 212(a)(27), 8 U.S.C. $\$ 1182(a)(27)$ (1982) ("prejudicial to the public interest, or endanger the welfare, safety, or security of the United States"), or INA 212(a)(29), 8 U.S.C. $\$ 1182(a)(29)$ (1982) ("activities ... prohibited by the laws of the United States relating to espionage, sabotage, public disorder, or in other activity subversive to the national security"). See Shapiro, supra note 29, at 932 n.16 for applicability of these sections to terrorist activity. 
authority of the executive branch to deport, to deny issuance of a visa to, or to deny admission to the United States of any alien

....

... who a consular official or the Attorney General knows or has reasonable ground to believe has engaged, in an individual capacity or as a member of an organization, in a terrorist activity or is likely to engage after entry in a terrorist activity . . .."383

The terrorist exception, like the PLO exception, is an exception to section 901's ban on ideological exclusion. Thus, it comes into play only when the government wants to exclude or deport an alien on the basis of the alien's expression or association. The exception itself is particularly broad in four respects: (1) it includes acts that are far removed in the chain of causation from an actual terrorist act; (2) it does not require a mental state of intent or knowledge; (3) it requires only a low standard of administrative certainty, since a consular or immigration official need only have a "reasonable ground to believe"; and (4) it encompasses situations in which there is only a suspicion that future terrorist activity is hikely. In all respects, the terrorist exception is substantially broader than the Brandenburg test would allow, since the terrorist exception is not confined to activity "directed to inciting or producing imminent lawless action and is likely to incite or produce such action."384

Despite the breadth of the terrorist exception in section 901(b)(2), that provision does not hinge on a mere associational or "membership" component. Both the statute and the Conference Coininittee Report expressly include the commission of terrorist acts while a member of an organization, but the emphasis is on the acts of terrorism. The language regarding membership ensures that the terrorist exception interdicts organizational as well as individual terrorist acts. Yet nothing in the terrorist exception permits aliens to be excluded solely on the basis of their membership in an organization that is traditionally linked with terrorism. Thus, the terrorist exception is consistent with section 901's stated

383. FRAA $\S 901(b), 1987$ U.S. CODE CONG. \& ADMIN. NEwS (101 Stat.) at 1400. The Conference Committee Report accompanying section 901 goes on to clarify this definition:

[I] $t$ is the intent of the managers to include persons involved in hostage taking, kidnaping, threatened violence or other acts which do not actually involve death or injury. These acts, whether or not they actually result in bodily harm, are a form of violence and are crimes. The managers also consider that organizing, abetting, or participating in terrorist acts or activities would include not only actually pulling a trigger or planting a bomb but providing support or assistance, such as but not limited to: planning, providing facilities, recruiting, financing or fundraising, surveillance, courier service, transportation, providing weapons, or forging or unlawfully procuring documents. ... An alien would be considered to have participated in an act of terrorism whether he or she did so individually or as a member of an organization.

CONFERENCE REPORT, supra note 68, at 164.

384. Brandenburg v. Ohio, 395 U.S. 444,447 (1969). 
goal of prohibiting exclusion for "an alien's mere membership in a Communist, anarchist, or other organization proscribed under current law."385

In contrast to the broad, yet carefully crafted and detailed terrorist exception, the PLO exception is cryptically blunt in its inconsistency with the rest of section $901 .^{386}$ Not only is the PLO exception both overinclusive and underinclusive, but given the existence of the terrorist exception, it is superfluous as well. For these reasons, it is difficult to see how the PLO exception furthers the government's goal of interdicting terrorism.

\section{b. Communicating Lack of Support for the PLO}

Another possible government interest behind the PLO exception is Congress' interest in communicating its positions on foreign policy. Congress surely intended to show that it does not support the goals or methods of the PLO, and singling out the PLO for such exceptional treatment certainly accomplishes this. Whether the means employed in furthering that goal are constitutionally permissible, however, must be evaluated by the final two prongs of the $O^{\prime} B r i e n$ test. ${ }^{387}$ It is worth noting, however, that regardless of the constitutionality of the PLO exception, furthering this foreign policy purpose in such a manner directly contradicts the stated statutory purpose of section 901 itself: to provide "citizens of the United States ... [with] the opportunity to have access to the full spectrum of international opinion, and [to preserve] the reputation of the United States as an open society, tolerant of divergent ideas ...." 388

385. CONFERENCE REPORT, supra note 68 , at 165 (emphasis added) .

386. The PLO exception is not even spelled out in section 901(b), but rather expressed only in the phrase "an alien who is described in section 21(c) of the State Department Basic Authorities Act of 1956 ..." Foreign Relations Authorization Act, Fiscal Years 1988 and 1989, Pub. L. No. 100 204, § 901(b), 1987 U.S. CODE CONG. \& ADMIN. NEWS (101 Stat.) 1331, 1400 (codified at 8 U.S.C. $\S 1182$ note (Supp. V 1987)), discussed at supra note 77.

387. The final two prongs of O'Brien state that " $[\mathrm{A}]$ government regulation is sufficiently justified ... if the governmental interest is unrelated to the suppression of free expression; and if the incidental restriction on alleged first amendment freedom is no greater than is essential to the furtherance of that interest." 391 U.S. at 377.

388. CONFERENCE REPORT, supra note 68 , at 163 . Aside from the constitutionality of the foreign policy purpose, such a purpose is expressly prohibited by language in section 901 itself. Section 901(b) states:

Nothing in this section shall be constrned as affecting the existing authority of the executive branch to [exclude]

... (1) for reasons of foreign policy or national security, except that such deportation or denial may not be based on past, current, or expected beliefs, statements, or associations which, if engaged in by a United States citizen . . . would be protected under the Constitution....

Foreign Relations Authorization Act, Fiscal Years 1988 and 1989, Pub. L. No. 100-204, $\S 901$ (b), 1987 U.S. CODE CONG. \& ADMIN. NEwS (101 Stat.) at 1400 (emphasis added). For the full text of section 901(b), see supra note 76. The inclusion of the very prohibition of section 901(a) itself in 


\section{Government Interest Unrelated to Suppression of Free Expression}

Like the resident-alien exception, ${ }^{389}$ the PLO exception appears to reflect government interests other than the suppression of free speech. This Comment presumes that those interests are the interdiction of terrorism and the expression of a foreign policy of antipathy to the PLO, neither of which, in itself, relates to expression or association. The way the PLO exception works, however, demonstrates that if the government is not interested in (i.e. intending) the suppression of free speech, its objectives clearly relate to the suppression of free speech. Aliens do not get excluded-under the PLO exception-from the United States because they are members of the PLO (and hence are terrorists or members of a disfavored foreign political entity) but rather because they are guilty of "beliefs, statements or associations which, if engaged in by a United States citizen . . . would be protected under the Constitution of the United States." 390

The $A D C$ v. Meese ${ }^{391}$ and Rafeedie v. INS ${ }^{392}$ cases demonstrate the direct and intimate relation of the PLO exception to the suppression of free speech. In both cases, the aliens found themselves severely sanctioned for association that is protected for U.S. citizens. In both cases, the INS attempted to exclude Palestinian resident aliens, who were active in Palestinian-American affairs and critical of United States-Middle East policies, by charging them under the purely ideological grounds of INA

section 901(b)(1) is an explicit congressional directive to the Executive not to conduct foreign policy through ideological exclusion.

The Conference Report further confirms that the intent of section 901(b)(1) is to prohibit ideological exclusion of aliens in the pursuit of foreign policy. It does state, however, that

it would still be appropriate, to the extent it is consistent with this section and existing law,

for the executive branch to deny a visa to an alien to avoid conveying the impression that

the U.S. Government recognizes or supports any government or group which the U.S. does

not choose to recognize or support.

CONFERENCE REPORT, supra note 68, at 163 (emphasis added).

On its surface, this language suggests that exclusion for reasons of foreign policy was a purpose that Congress considered appropriate when it passed section 901. Further examination of the Conference Report, however, reveals that this purpose was not to allow the exclusion of PLO members for membership alone as a foreign policy tool. In the first place, the Conference Report requires that such a foreign policy purpose be "consistent with this section." Id. The PLO exception (at least for mere members) clearly is not, because it authorizes exclusion of a PLO member regardless of whether her membership would be constitutionally protected for a U.S. citizen. Second, the Conference Report goes on to give several examples of permissible foreign policy uses of exclusion, none of which involves singling out a member of a group solely on the basis of expression or association. All involve some aspect of activity beyond mere association.

Thus, as a matter of statutory construction, using the PLO exception to express opposition to the PLO is forbidden by section 901 itself.

389. See supra notes 296-354 and accompanying text.

390. $\S 901$ (a), 1987 U.S. CODE CONG. \& ADM1N. NEwS (101 Stat.) at 1400.

391. 714 F. Supp. 1060 (C.D. Cal. 1989), discussed at supra notes 187, 196, $368 \& 379$ and accompanying text.

392. 688 F. Supp. 729 (D.D.C. 1988), discussed at supra notes 8-17, 25 and accompanying text. 
section 212(a)(28). ${ }^{393}$ In neither case was their attempted exclusion based on either the potential for terrorism or their membership in an antagonistic national entity. In Rafeedie, a U.S. citizen who made the same trip to the PLO-affiliated conference was completely free to go on his way. ${ }^{394}$ The director of the FBI admitted that the resident aliens in $A D C$ v. Meese were arrested for activity that would have been legal for U.S. citizens. ${ }^{395}$ Yet $\dot{m}$ both cases the government maintamed that the PLO exception to section 901 authorized the exclusion of resident aliens for expression or association that is constitutionally protected for U.S. citizens. Of necessity, therefore, any alien who is interested in the cultural aspects of the Palestinian-American community or the political issues of Middle East policy must be cautious about contacting organizations that can be characterized as affiliated with the PLO.

As in the case of the resident-alien exception, ${ }^{396}$ the fact that the government interest behind the PLO exception relates to the suppression of speech yields three possible conclusions. First, one may conclude that the O'Brien test is inappropriate and that the analysis should therefore be "switched" to the more severe, categorical test of Brandenburg $v$. Ohio. ${ }^{397}$ Under Brandenburg, the PLO exception quickly fails since it does not provide any mechanism for determining whether a PLO member has engaged in conduct "directed to inciting or producing imminent lawless action and is likely to incite or produce such action." 398

Second, without concluding that the tests should be switched, one may still determine that the effects of the PLO exception are so much more detrimental to free speech than they are helpful in furthering the non-speech-related government interests that they are not truly "incidental" to those interests. In the final balancing of the prongs of the O'Brien test, such a determination weighs heavily against a finding of constitutional validity.

Third, the conclusion can be drawn that the government interest not only relates to the suppression of free speech, but that the government interest $i s$, at least partially, the suppression of free speech. It is certainly plausible that legislation singling out PLO members for ideological exclusion is motivated by disapproval of their ideology. Certainly the ideology of the PLO, regardless of how heterodox, ${ }^{399}$ is widely unpopular with the U.S. public and its lawmakers. It defies common sense to suggest that disagreement with the views expressed by many members of the

393. 8 U.S.C. §1182(a)(28) (1982), quoted at supra note 49.

394. Rafeedie v. INS, 688 F. Supp. 729 (D.D.C. 1988). See supra text accompanying notes 8-11.

395. See supra text accompanying note 24.

396. See supra notes $296-354$ and accompanying text.

397. 395 U.S. 444, 447 (1969). The Brandenburg test is quoted supra at note 297.

398. Brandenburg, 395 U.S. at 447.

399. See infra notes $413-414$ and accompanying text. 
PLO were not part of the congressional purpose in adding the PLO exception to section 901's prohibition on ideological exclusion. It is equally plausible that such a purpose would not be articulated by Congress as one of its reasons for enacting the PLO exception. ${ }^{400}$

The conclusion that at least part of the purpose of the PLO exception is to suppress speech requires further analysis. Such a conclusion can prompt a variety of responses. It can argue, again, for switching to Brandenburg. Or, it can argue for reassessing the second prong of the O'Brien test-whether the exception furthers an important or substantial government interest. Finally, it can argue that prong three, itself, militates against constitutional validity in the ultimate O'Brien balancing.

Any of these responses is complicated by the fact that speech suppression is only part of the congressional purpose in enacting the PLO exception, for it is obvious that non-speech-related interests also animated Congress. The $O^{\prime} B r i e n$ test does not provide guidance for dealing with legislation prompted by multiple government interests, one of which is speech suppression. ${ }^{401}$ The Brandenburg test does not consider government interests at all. ${ }^{402}$ A strict policy of protecting first amendment interests suggests either switching to Brandenburg or finding government action unconstitutional under either prong two or three of O'Brien whenever any substantial motivation is the suppression of speech. Such rigorous protection of first amendment values may well be appropriate but will not be urged in this case.

Rather than argue that the apparent speech-suppressive purpose of the PLO exception dispositively determines the constitutional invalidity of that exception, this Comment will only argue that such a purpose be considered as one factor militating against the exception's validity in the ultimate balancing of the other factors raised by the O'Brien test. The reason for adopting this more accommodating test is twofold. First, this is an argument for judicial review of immigration legislation. Such legislation has traditionally not been expected by either Congress or the courts to measure up to constitutional standards. Thus, perhaps Congress should be given the benefit of the doubt. Second, both interdicting

400. "Restrictions on free expression are rarely defended on the ground that the state simply didn't like what the defendant was saying; reference will generally be made to some danger beyond the message, such as danger of riot, unlawful action or violent overthrow of the government." Ely, supra note 321 , at 1496 .

401. The O'Brien court (charitably) assumed that the various purposes suggested by government counsel for continuous possession of draft cards (for example, proof of draft registration, facilitating communication between registrants and draft boards, reminder to registrant of registration obligations) exhausted the congressional intent in banning the destruction of draft cards.

402. See Ely, supra note 321, at 1491 . 
terrorism and executing foreign policy are exceedingly inportant government interests and the case can be made for giving the fullest opportumity for vindication of the PLO exception in its pursuit of those goals. For these reasons, the apparent partial interest of Congress in suppressing speech through the PLO exception will be treated only as a factor on the negative side of the scale of a comprehensive O'Brien balancing.

\section{No Greater Than Essential Restriction on First Amendment Interests}

The fourth prong of the O'Brien test requires that any restriction on first amendment freedoms be "no greater than is essential to the furtherance of [the government] interest." 403 Compared to the terrorist exception of section 901(b)(2), ${ }^{404}$ the PLO exception is clearly not well-tailored to the purpose of interdicting terrorism. Like the statute barring Communist Party members from employment in defense plants, struck down in United States v. Robel, ${ }^{405}$ the

statute casts its net across a broad range of associational activities, indiscriminately trapping membership which can be constitutionally punished and membership which cannot be so proscribed. It is made irrelevant to the statute's operation that an individual may be a passive or inactive member of a designated organization, that he may be unaware of the organization's unlawful aims, or that he may disagree with those unlawful aims. ${ }^{406}$

In this sense, the PLO exception is also similar to the statute in Aptheker v. Secretary of State, ${ }^{407}$ which prohibited travel for those who merely associated with the Communist Party. The Aptheker Court noted that "the fact of membership in that group [was] the sole criterion for limiting the individual's freedom," 408 and that the statute "render[ed] irrelevant the member's degree of activity in the organization and his commitment to its purpose [or] the type of activity which Congress sought to control."409 Thus, the Court concluded that " "[i]ndiscriminate classification of innocent with knowing activity must fall as an assertion of arbitrary power." "410 Similarly, in Rafeedie v. INS ${ }^{411}$ Judge Green

403. United States v. O'Brien, 391 U.S. 367,377 (1968).

404. Foreign Relations Authorization Act, Fiscal Years 1988 and 1989, Pub. 100-204, $\S 901(b)(2), 1987$ U.S. CODE CONG. \& ADMIN. NEwS (101 Stat.) 1331, 1400 (codified at 8 U.S.C. $\S 1182$ note (Supp. V 1987)), discussed at supra notes 383-386 and accompanying text.

405. 389 U.S. 258 (1967).

406. Id. at $265-66$.

407. 378 U.S. 500 (1964).

408. Id. at 510 .

409. Id.

410. Id. (quoting Wieman v. Updegraff, 344 U.S. 183, 191 (1952)).

411. 688 F. Supp. 729 (D.D.C. 1988), discussed at supra notes 8-17, 25 and accompanying text. 
stated that "mere association with an organization that advocates violence or terrorism, without proof that the individual's "association poses the threat feared by the Government" is an impermissible basis upon which to deny First Amendment rights." "412

Applying section 901 to all members of the PLO is certain to ensnare PLO members who have no terrorist propensities. This self-evident conclusion is corroborated by evidence that the PLO is not an organization monolithically committed to violence, but rather a heterogenous organization whose members possess diverse views, goals, and strategies. Before the House Committee on Foreign Affairs, former Assistant Secretary of State Harold Saunders testified:

The PLO is a collection of organizations whose principal purpose is establishing some sort of homeland for the Palestinian people. They engage in a lot of activities in that context. Some of them are to provide health services and educational services for Palestinians. Others have involved acts of terrorism across international borders and against international airlines in the past.

So, they have in pursuing their war of liberation, as they call it, they have engaged in military activities, in maintaining the support of their people they have engaged in humanitarian activities. ${ }^{413}$

412. Id. at 752 (quoting Healy v. James, 408 U.S. 169, 186 (1972), quoting in turn United States v. Robel, 389 U.S. 258, 265 (1967)) (holding that a Students for a Democratic Society (SDS) ehapter could not be denied campus privileges because of alleged ties to a violent national organization). Thus, the congressional finding that the PLO is a terrorist organization (see supra note 374) does not legitimate the PLO exception as a means for interdicting terrorists. That finding was addressed to a different issue (operation of PLO missions in the United States) and did not conclude that all members of the PLO are terrorists.

413. Iran's Seizure of the United States Embassy, 1981: Hearings Before the House Comm. on Foreign Relations, 97th Cong., 1st Sess. 122 (198I) [hereinafter Iran Hearings] (statement of Harold Saunders, Assistant Secretary of State for Near Eastern and South Asian Affairs. Other congressional testimony corroborates Mr. Saunders' statement. For example, a former foreign service officer declared that "members of the Executive Committee [of the PLO] and of the Congress represent organizations of Palestinians formed for diverse purposes: social, such as clubs; labor organizations; trade organizations; and activist, even guerrilla organizations." Perspectives on the Middle East Peace Process, 1981: Hearings Before the Subcomm. on Europe and the Middle East of the House Comm. on Foreign Affairs, 97th Cong., 1st Sess. 107 (1981) [hereinafter Middle East Hearings] (statement of Joseph Greene, Foreign Service officer, 1942-73; Chief of U.S. Interests Section in Cairo, 1973).

In her thorough study of the PLO, professor Cheryl Rubenberg stated:

[T] he PLO provides comprehensive medical and health services, an economic infrastructure, the cultural focus, the educational basis, social welfare services, and so forth, in a manner comparable to that of any sovereign territorial state.

... [T]he existence of the civil institutions of the PLO and the extent of their activities, in addition to the political institutions and the processes of interaction in the play of Palestinian politics, are testament to the fact that the PLO is not only a military organization. Indeed the military activities of the PLO pale in magnitude, sophistication, and complexity in comparison with its civilian activities.

C. Rubenberg, The Palestine Liberation Organization: Its Institutional InfrastrucTuRe 58-59 (1983); see also H. CobBan, The PLO: People, Power and Politics 14 (1984) 
In fact, given the porous nature of "membership" in the PLO, ${ }^{414}$ the PLO exception effectively excludes most Palestimians from the benefit of section 901. As such, the PLO exception comes close to being based solely on national origin. An exception based on national origin may be unconstitutional even under the deferential "facially legitimate and bona fide" standard articulated in Kleindienst v. Mandel ${ }^{415}$ and Fiallo v. Bell. ${ }^{416}$

A final illustration that the PLO exception is not tailored to interdicting terrorists im the least restrictive fashion is demonstrated by comparing it to the other exceptions to section 901(a). All of the other exceptions are tailored to excluding only those aliens who have engaged or are likely to engage im proscribed activity. Section 901(b)(3) excludes labor union officials from totalitarian states, but only when such an alien "seeks to enter in an official capacity."417 Likewise, the exception for asylum seekers is limited to those aliens who, themselves, actively persecuted others. ${ }^{418}$

The Nazi exception ${ }^{419}$ is particularly illustrative of the overbreadth of the PLO exception. The Nazi exception is tailored to excepting from

414. Harold Saunders, testifying at the Iran Hearings, stated,

I don't know how one defines a PLO sympathizer. One of the West Bankers said to me that we are all members of the PLO. He was speaking mystically and philosophically that they are parts of the Palestinian movement. There is no such thing in the West Bank as a member of the PLO, the PLO at large. They are not card-carrying and noncard-carrying people.

Iran Hearings, supra note 413, at 30.

According to Professor Rubenburg, the PLO is not an organization to which one officially belongs, but rather it is a umbrella organization to which many diverse Palestinian organizations send representatives. Technically, the only literal "members" of the PLO are the members of the PLO Executive Committee and National Congress. C. RUBENBERG, supra note 413, at 58-59.

415. 408 U.S. 753,770 (1971).

416. 430 U.S. 787, 794 (1977). C. Gordon and S. Mailman, prominent commentators on immigration law, have stated that " $[t]$ he apparent thrust of the Court's suggestion is that the 'limited judicial review' might be invoked . . . to challenge the most blatant type of discrimination, e.g. exclusions based solely on race." 1 C. GoRdon \& S. MAILMAN, IMMIGRATION LAW AND Procedure § 9.01, at 9-5 (1989) (quoting Fiallo v. Bell, 430 U.S. 787, 795 n.6).

417. Foreign Relations Authorization Act, Fiscal Ycars 1988 and 1989, Pub. L. No. 100-204, \$ 901(b)(3), 1987 U.S. Code CoNG. \& ADMIN. NEws (101 Stat.) 1331, 1400 (codified at 8 U.S.C. $\S 1182$ note (Supp. V 1987)). For the full text of $\S 901(b)$, see supra note 76 . Thus, mere union membership would not be proscribed because an alien entering the U.S. in an official capacity would have to be entering as a representative, officer, or spokesperson for the union. See supra note 356.

418. $\$ 901(\mathrm{~b})(3), 1987$ U.S. Code Cong. \& Admin. News (101 Stat.) at 1400 . For text of the exception for asylum seekers, see supra note 76.

419. Id. The Nazi exception is stated as, "an alien who is described in section 212(a)(33) of the Immigration and Nationality Act." INA § 212(a)(33) makes excludable:

Any alien who ... under the direction of, or in association with-

(A) the Nazi government in Germany,

(B) any government in any area occupied by the military forces of the Nazi government in Germany,

(C) any government established with the assistance or cooperation of the Nazi government of Germany, or

(D) any government which was an ally of the Nazi government of Germany ordered, 
the benefit of section 901 those guilty of Nazi persecution, but it is not overinclusive because it only includes those who participated in that persecution. Thus, Congress, in creating the Nazi exception to section 901 , chose to expose to the risk of ideological exclusion all aliens who "ordered, incited, assisted, or otherwise participated in the persecution of any person because of race, religion, national origin or political opinion." ${ }^{\prime 20}$ Notably, they did not choose to except from section 901's protection Nazi members who did not actively perpetrate the horrors of that era, but who, without doubt, bear moral responsibility for those horrors. The Nazi exception is therefore consistent with Congress' intent to make section 901's protection against ideological exclusion coterminous with domestic first amendment protection. Brandenburg v. Ohio ${ }^{421}$ demonstrates that, as odious as it is, membership in the Nazi party, or Nazi speech, without more, is clearly protected for U.S. citizens by the first amendment. ${ }^{422}$

Furthermore, the Nazi exception is not underinclusive because it is not limited to only members of the Nazi party but also includes any alien who participated in Nazi persecution, whether or not as a member of the Nazi party. Thus, the Nazi exception is a model illustration of "welltailored" means to an end. The PLO exception, by contrast, necessarily includes many nonterrorists and does not include any non-PLO terrorists.

incited, assisted, or otherwise participated in the persecution of any person because of race, religion, national origin, or political opinion.

INA § 212(a)(33), 8 U.S.C.A. § 1182(a)(33) (West Supp. 1989).

420. Id.

421. 395 U.S. 444 (1969).

422. Brandenburg overturned a conviction of a Ku Klux Klan leader for giving a racist speech. 395 U.S. 444 (1969), discussed at supra note 297; see also Terminiello v. Chicago, 337 U.S. 1 (1949) (overturning a breach of peace conviction based on a jury instruction that authorized conviction for advocacy which "stirs the public to anger, invites dispute or brings about a condition of unrest." The speech in question "vigorously, if not viciously criticized various political and racial groups whose activities he denounced as inimical to the nation's welfare." Id. at 3.); cf. Feiner v. New York, 340 U.S. 315 (1951) (upholding a conviction for disorderly conduct for inflammatory speech, the Court stated, "it is one thing to say that the police cannot be used as an instrument" for the suppression of unpopular views, and another to say that, when as here the speaker passes the bounds of argument or persuasion and undertakes incitement to riot, they are powerless to prevent a breach of the peace." Id. at 321)

The closest the Supreme Court has come to expressly protecting Nazi membership or speech has been in denying certiorari in Collin v. Smith, 578 F. 2 d 1197 (7th Cir.), cert. denied, 439 U.S. 916 (1978). In Collin, the court invalidated a Village of Skokie, Illinois "Racial Slur" Ordinance prohibiting, inter alia, "public display of markings and clothing of symbolic significance" promoting and inciting racial or religious hatred. The ordinance was intended to prohibit the display of swastikas and the wearing of Nazi uniforms. The court quoted Street v. New York, 394 U.S. 576 (1969), "public expression of ideas may not be prohibited merely because the ideas are themselves offensive to some of their hearers." Id. at 592, quoted in Collin. 578 F. 2d at 1206. 
The purpose to "avoid conveying the impression that the U.S. Government recognizes or supports"423 the PLO is equally capable of being achieved through less onerous alternatives. Congress is free, through a wide variety of diplomatic and political means, to express its position on the $\mathrm{PLO}^{424}$ without directly and expressly curtailing the freedom of aliens to associate with the PLO, or the freedom of U.S. citizens to associate with members of the PLO. ${ }^{425}$ It is obviously important and legitimate for Congress to express positions of support for and alignment with various foreign groups and nations. The courts have even held, as in the Iraman student cases, ${ }^{426}$ that it is legitimate to do so at the expense of individual aliens. But the point of O'Brien is that Congress cannot do so in a manner that suppresses free speech unless that action is no more restrictive of free speech than essential to achieve its goals. Unquestionably, the U.S. government has been able to make known its position on the PLO to the rest of the world without denying to PLO members the same protections against ideological exclusion as it has offered to other aliens.

\section{Balancing the O'Brien Prongs}

Applying the O'Brien prongs to the PLO exception requires the conclusion that its putative legitimate purposes do not justify the suppression of free speech that is the direct result of its operation. As regards the purpose of interdicting terrorists, the PLO exception is extravagantly overbroad, casting its net to indiscrimmately ensnare mnocent and guilty alike. As regards the purpose to express antipathy to the PLO, the exception achieves that goal effectively, but that end can be achieved in a variety of other ways that do not restrict free expression.

423. CONFERENCE REPORT, supra note 68 , at 163.

424. For example, the State Department Basic Authorities Act of 1956, as amended by Pub. L. No. 99-93 $\$ 127(d)(3) 99$ Stat. 405, 418 authorizes the closure of foreign missions when "necessary to protect the interests of the United States." Id. at 22 U.S.C. $\$ 4305(\mathrm{~b})(3)$, discussed at supra note 287; see also PIO v. Shultz, 853 F.2d 932 (D.C. Cir. 1988) (upholding the State Department ordered closing of the Palestine Information Office).

425. In Harvard Law School Forum v. Shultz, the Court stated:

Although the Secretary's proffered reason for denying the request [to travel to debate Middle East policy] involves the executive's policy of not affording recognition to the PLO, the case is not a challenge to that policy. A determination of the constitutionality of the Secretary's conditioning of a waiver of excludability ... does not impinge upon the executive's conduct of foreign relations simply because the individual at issue is a member of a non-recognized foreign entity.

633 F. Supp. 525, 529 (D. Mass. 1986), vacated without opinion 852 F.2d 563 (1st Cir. 1986). The district court opinion was vacated on appeal because its holding had been rendered moot by the passage of time.

426. Narenji v. Civiletti, 617 F.2d 745 (D.C. Cir. 1979) (upholding INS regnlations requiring Iranian students to report to INS and prove conformity with visa status), cert. denied, 446 U.S. 957 (1980); Yassini v. Crosland, 618 F.2d 1356 (9th Cir. 1980) (upholding INS decision to withdraw deferred departure status from certain Iranian students and to move to deport them); Shoaee v. INS, 704 F.2d 1079 (9th Cir. 1983) (upholding an Iranian student's deportation for overstaying the expiration of his visa), discussed at supra notes 276-277 and accompanying text. 
Perhaps most importantly, this application of $O^{\prime} B r i e n$ forces a close enough examination of the PLO exception to reveal that what it doesand all it does-is suppress free speech, both for PLO members and for U.S. citizens. Whether such was the purpose of its enactment or it just happened that the "incidental" (but direct) speech-suppressive effect overwhelmed the legitimate (but indirect) effects, the function of the PLO exception is to single out PLO members for ideological exclusion, without regard for past or future dangerous activity.

A statutory classification that strays this far from the constitutional constraints of the first amendment invites suspicion that its purpose is "a bare congressional desire to harm a politically unpopular group."427 Uncovering such a purpose, even if justified in the name of foreign policy or counterterrorism, demonstrates the importance of submitting such measures to constitutional scrutiny, thereby " 'flushing out' unconstitutional motivation." 428

Thus, we must balance the pronounced, and perhaps purposeful, suppression of free speech against two interests, one of which is not even furthered by the PLO exception, and both of which can be accomplished without injury to freedom of expression and association. The conclusion of such a balancing must be that the benefits gained by the PLO exception do not warrant its harm to "the United States as an open society, tolerant of divergent ideas." 429

\section{CONCLUSION}

This Comment has argued that the plenary power doctrine should be abandoned because it is supported by neither precedent nor rationale and is an affront to the constitutional values of a free and tolerant society. Alternatively, the plenary power doctrine should not preclude the review of first amendment challenges to immigration legislation or executive action. Freed from the restraints of the plenary power doctrine, this Comment has subjected two of the statutory exceptions to section 901 of the Foreign Relations Authorization Act, Fiscal Years 1988 and 1989 to first amendment scrutiny. ${ }^{430}$ That scrutiny revealed severe constitutional

427. United States Dep't of Agric. v. Moreno, 413 U.S. 528, 534 (1972) (invalidating a statute barring households of unrelated persons from receiving food stamps, finding that the true purpose of the statute was to harm "hippies," not to minimize food stamp fraud).

428. J. Ely, DEMOCRACY AND DisTRUST 146 (1980).

429. CONFERENCE REPORT, supra note 68 , at 163 . The quote is from that part of the Report that states that because of ideological exclusion,

"[T] he citizens of the United States have been denied the opportunity to have access to the full spectrum of international opinion, and the reputation of the United States as an open Id.

society, tolerant of divergent ideas, has suffered."

430. Pub. L. No. 100-204, 1987 U.S. CoDE Cong. \& ADMIN. News (101 Stat.) 1331 (codified at 8 U.S.C. $\$ 1182$ note (Supp. V 1987)), as amended by Foreign Operations, Export Financing, and 
problems which would remain unexannined and unsolved under the traditional attitude of categorical judicial deference. According to the test set out in United States v. O'Brien, ${ }^{431}$ withholding the Act's protection against ideological exclusion from iminigrant aliens and menbers of the PLO flagrantly violates the first ainendment. Therefore, Congress should revise section 901 to inake it fully conform to its stated purpose of allowing full access to divergent ideas. Alternatively, the courts should accept their responsibility to adjudicate the constitutional challenges to section 901 and overturn these two offensive provisions.

431. 391 U.S. 367,377 (1968). 
